\title{
Subtask 3.12 - Small Power Systems
}

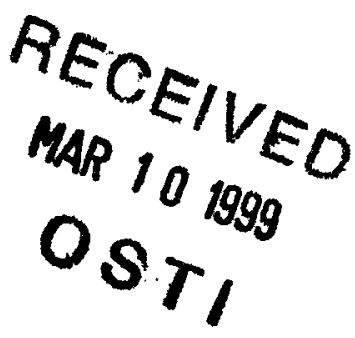

Final Topical Report

January 1 - June 30, 1997

By

\section{Michael D. Mann; Mark D. Kurz; Lanny Schmidt Michelle Kjeden; Chris Sprynczynatyk}

Work Performed Under Contract No.: DE-FC21-93MC30097

For

U.S. Department of Energy

Office of Fossil Energy

Federal Energy Technology Center

P.O. Box 880

Morgantown, West Virginia 26507-0880

By

Energy \& Environmental Research Center

University of North Dakota

P. O. Box 9018

Grand Forks, North Dakota 58202-9018 


\section{Disclaimer}

This report was prepared as an account of work sponsored by an agency of the United States Government. Neither the United States Government nor any agency thereof, nor any of their employees, makes any warranty, express or implied, or assumes any legal liability or responsibility for the accuracy, completeness, or usefulness of any information, apparatus, product, or process disclosed, or represents that its use would not infringe privately owed rights. Reference herein to any specific commercial product, process, or service by trade name, trademark, manufacturer, or otherwise does not necessarily constitute or imply its endorsement, recommendation, or favoring by the United States Government or any agency thereof. The views and opinions of authors expressed herein do not necessarily state or reflect those of the United States Government or any agency thereof. 


\section{DISCLAIMER}

Portions of this document may be illegible in electronic image products. Images are produced from the best available original document. 


\section{TABLE OF CONTENTS}

LIST OF FIGURES $\ldots \ldots \ldots \ldots \ldots \ldots \ldots \ldots \ldots \ldots \ldots \ldots \ldots$

1.0 INTRODUCTION $\ldots \ldots \ldots \ldots \ldots \ldots \ldots \ldots \ldots \ldots \ldots \ldots \ldots \ldots \ldots \ldots$

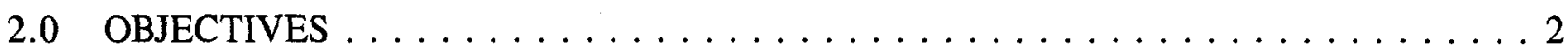

3.0 THE INTEGRATED MUNICIPAL SERVICES SYSTEM CONCEPT $\ldots \ldots \ldots \ldots$

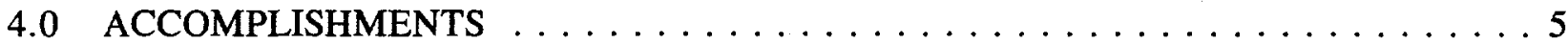

INTEGRATED MUNICIPAL SERVICES SYSTEM RESULTS FROM A CASE

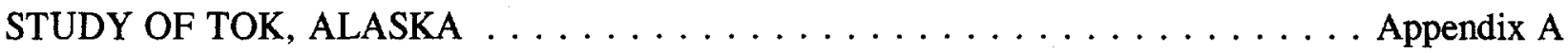

\section{LIST OF FIGURES}

1 Schematic of the integrated municipal services system (IMSS) $\ldots \ldots \ldots \ldots$ 


\section{SUBTASK 3.12 - SMALL POWER SYSTEMS}

\subsection{INTRODUCTION}

One of the overall goals of the U.S. Department of Energy (DOE) is the development of the technology necessary to provide for a secure, reliable, affordable, and environmentally sound source of energy. This technology is important to ensure economic stability and growth in the next century as well as to reduce current and minimize future environmental impact associated with power generation in the United States and the world.

Throughout the world, coal will play an expanded role in the production of affordable energy necessary to meet the demands of economic development and growth. The development of more efficient and environmentally sound technology in the United States may present export market opportunities throughout the world. For coal to play a key role in the energy mix, it will be necessary to develop and commercialize technologies capable of producing electricity at significantly higher overall system efficiencies with minimum emissions. A number of demonstration projects addressing these needs for large utility plants are being performed under the Clean Coal Technology Program. A need also exists for smaller (20-kW to 20-MW) systems to satisfy the needs of remote-site markets. Many of these markets are in areas where a small increment of power is needed to meet demand and the installation of transmission lines to bring in the power is not practical or economical. Diesel engines have traditionally filled this market niche; however, some of the advanced power systems currently under development could provide power more economically and with reduced environmental risk. Innovative solutions to barrier issues that are in some measure common to all advanced power system processes can be developed and demonstrated more economically and effectively in small-scale systems. Examples are material issues involving ceramic and refractory components and operational issues unique to hightemperature pressurized systems.

Because of their size, small communities are faced with a variety of problems that make the construction and operation of communitywide managed waste and wastewater cleanup, reuse, and/or disposal a difficult undertaking. Many communities in rural America have been losing population as a result of migration to large urban areas. Concurrently, federal and state regulations pertaining to waste disposal and water supply treatment have become more stringent. Small communities must provide the same degree of treatment that is now provided by large communities. Small communities cannot enjoy the economies of scale that are possible with the construction of waste and wastewater treatment facilities for larger communities. In addition, the economic base of smaller communities is often not large enough to support the added burden of more sophisticated treatment facilities, further stressing the resources of these rural communities. In many cases, the smaller communities have a lower per capita income, a residential tax base with few commercial or industrial entities, and difficulties in arranging financing because of low bond ratings. In many cases, the small community has limited economic resources and experience to manage wastewater treatment facilities. Problems are often experienced in design, contracting, inadequate construction supervision, project management, billing, accounting, budgeting, and maintenance. The need to overcome these problems makes the implementation of treatment facilities in the United States a major undertaking. Low-maintenance solutions must be developed to provide proper water and waste treatment for small communities. 
In many developing countries, waste disposal and water treatment capabilities are not available to the general population outside the larger urban centers because of a lack of infrastructure. Access to required power supplies is extremely limited, and power generation capabilities are nonexistent. Of particular concern is the increasing number of outbreaks of infectious diseases within the last 30 years in these areas. With increased frequency, concern has risen over the potential for transmission of these diseases to other countries. At least partially, the trend for increasing infectious disease occurrences has been attributed to human-induced environmental stress and the lack of even the most rudimentary control techniques in many areas of the world. It is now becoming evident that the best method for controlling infectious disease is through the development and implementation of preventive measures and containment capabilities.

During the past 15 years, interest in small treatment systems has been overshadowed by design, construction, and operation of large regional systems. Small systems were often designed and constructed as small-scale models of larger plants. As a consequence, many are operationally energy- and resource-intensive. Greater attention needs to be focused on the design, operation, and maintenance of individual on-site systems. Decentralized technologies can reduce construction costs, minimize operation and maintenance costs, lower energy consumption, and drop infrastructure requirements as compared to the centralized options. These technologies are especially important in areas where centralized options are not possible.

The health and pollution hazards, including groundwater contamination, caused by the use of such systems warrant special attention and represent an area of need not only in the United States, but worldwide. In many cases, although effective treatment methods exist to provide safe drinking water and disposal of wastes, lack of sophistication and funds may impede implementation of these methods. Some small systems do not have access to skilled technicians, good support services, or the economies of scale available to larger systems.

\subsection{OBJECTIVES}

The programmatic goal in advanced power systems is to develop small integrated waste treatment, water purification, and power systems in the range of $20 \mathrm{~kW}$ to $20 \mathrm{MW}$ in cooperation with commercial vendors. These systems will be designed to incorporate the advanced technical capabilities of the Energy \& Environmental Research Center (EERC) with the latest advancements in vendor-offered hardware and software. The primary objective for the work to be performed under this subtask is to develop a commercialization plan for small power systems, evaluate alternative design concepts, and select practical and economical designs for targeted development in upcoming years. A leading objective for the EERC will be to continue to form strong business partnerships with equipment manufacturers who can commercialize the selected power system and treatment design(s).

FY95 activities were focused on collecting information from vendors and evaluating alternative design concepts. This year's activities began with the process of selecting one design for targeted development. A case study was performed to determine if the combination of water and waste treatment with power generation could improve the economics over a stand-alone power generation system. 


\subsection{THE INTEGRATED MUNICIPAL SERVICES SYSTEM CONCEPT}

The solution to the energy, water, and waste treatment needs of the small community involves the use of integrated energy and environmental technology modules to meet the specific needs of each community. This modular approach uses new and existing technologies to provide waste disposal, water supply purification, wastewater treatment, and power generation capabilities on a scale appropriate to the situation. Integration of specific modules allows the total needs of the community to be met. In some cases, a specific technology such as fluid-bed combustion can be used to solve several problems. Fluid-bed combustion can be used to dispose of agricultural, industrial, and municipal solid wastes and sludges while utilizing these carbon sources for the production of energy or heat. The use of integrated, multifunctional modules increases flexibility, mobility, efficiency, and cost-effectiveness.

Several components must be considered in selecting wastewater treatment and water purification technology, the main consideration being the ability of the process to destroy microorganisms. In addition to their biological disinfection capabilities, these technologies must require relatively low maintenance, be modular and transportable, and be relatively cost-effective. Community size and geographical constraints must also be taken into account in selecting a technology. Several treatment options exist that can be used alone or in a treatment series to solve one or several problems. These options include ultraviolet radiation, ozonation, reverse osmosis, filtration, chemical treatment, and distillation. Also, these systems can be designed to address a variety of water disposal situations, from well-drawn water to wastewater and industrial process water. The benefits realized by this approach include a potential for economic development, protection of the environment, improvement of health for community members, job creation, and a general improvement in the quality of life.

This concept revolves around packaged systems, each a proven technology, integrated in such a manner as to take advantage of the synergistic effects that the treatment and power generation modules offer each other. Technologies that are easy to install and operate are particularly appropriate for use in package plants. These treatment plants are factory-designed to implement effective methodologies in the more restricted conditions typical of remote applications. The "packaged plant" modularity of the units is meant to address the financial, operational, regulatory, and installation limitations that hamper small water and waste treatment ability to deliver safe waste and comply with current disposal standards.

The ultimate disposal of the solid and semisolid residuals (sludge) and concentration contaminants removed by treatment has been and continues to be one to the most difficult and expensive problems in the field of wastewater engineering. Recent legislation banning the ocean discharge of sludge has eliminated one disposal option used by some large coastal cities. Because of concerns about air and groundwater pollution, the disposal of sludge by incineration and by the application on land or in landfills offers an attractive alternative. Land application of sludge is used extensively as a means of disposal, as a means of reclaiming marginal land for productive use, and as a means of utilizing the nutrient content in the sludges. However, landfilling and land application of sludge are becoming more strictly regulated, and landfill sites for the disposal of sludge are more difficult to locate. Landfilling and land application are also poor choices when infectious diseases are a concern. 
The integration of the power system with the water and waste treatment facilities offers a solution to the problem of sludge disposal. The fluid-bed combustor offers a means to destroy the pathogens that cause serious health problems in some communities and greatly reduces the volume of material for final disposal. The integration of the power generation module with waste disposal, wastewater treatment, and water purification is depicted in Figure 1. The synergistic effects of integrating these modules can be clearly seen. For example, the power generation system can provide steam, heat, and/or electricity to any of the other modules while accepting the sludges generated from the various treatment processes as its fuel. Having a use for the low-level heat that is produced from the power generation system helps improve its overall efficiency and thereby reduce the overall cost of electricity to the consumer. Likewise, having the ability to route difficultto-dispose-of sludges to the power generation system, rather than to a costly landfill or to a site for further treatment, can significantly reduce the cost of the treatment option.

The overall function of the integrated municipal services system (IMSS) is to supply cheap and efficient power, water, and waste treatment for domestic and industrial use. This is essential to sustain any community. A very attractive benefit of the IMSS is to provide the opportunity for economic development. If properly designed, the IMSS should produce a relatively inexpensive source of steam, heat, electricity, and water and an established and convenient method of dealing with the by-products produced from new economic developments. These developments not only benefit the community in the traditional manner, but also will help reduce the overall cost of power and treatment to the individual resident.

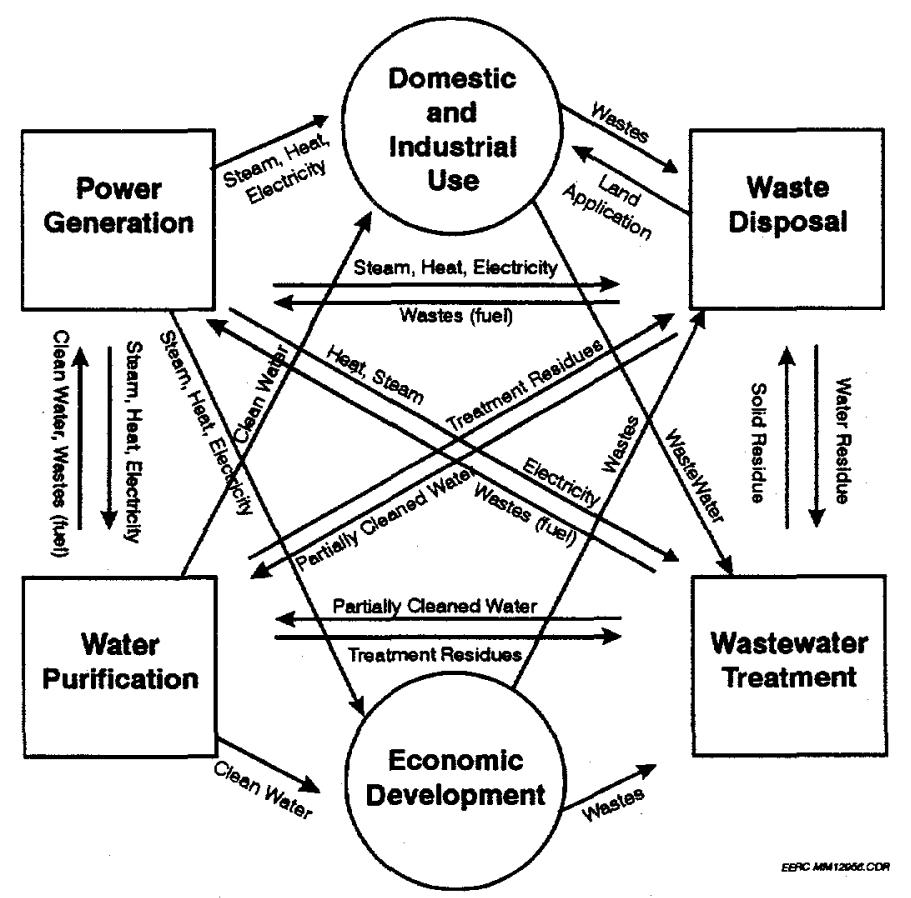

Figure 1. Schematic of the integrated municipal services system (IMSS). 


\subsection{ACCOMPLISHMENTS}

A case study was completed to determine the preliminary feasibility of an IMSS for a small community (See Appendix A for the detailed report). The case study is focused on the community of Tok, Alaska. This city was chosen firstly because it fit the profile for the type of community that would benefit from an IMSS, and secondly because other ongoing studies have generated much of the input data required for this analysis.

Tok is a small community with a population of approximately 1250 . There are 537 residential homes, 135 commercial facilities, and 32 community facilities. There is currently no centralized water or sewage system. Seventy-five percent of the water used is extracted from wells, with the remaining coming from the Tanana River. Sixty percent of the wastes are disposed of in septic or cesspool systems, with the remaining $40 \%$ going to an open landfill. This landfill, like others throughout the United States, is facing closure unless major investments are made to bring it into compliance with current regulations.

Electricity is currently generated using diesel generator sets. The cost of power of $\$ 0.20 / \mathrm{kWh}$ for Tok is relatively low compared to other small Alaskan communities, but very high compared to the cost in the lower 48 states. The usage for 1994 was $5285 \mathrm{kWh}$ for residential, $20,000 \mathrm{kWh}$ for commercial, and $980,000 \mathrm{kWh}$ for community facilities. The cost of fuel oil to Tok and other Alaskan communities is very high, ranging from $\$ 1$ to $\$ 5$ per gallon because of the cost of shipping the oil to the remote sites.

Heating is currently provided by fuel oil for commercial and community facilities. Fuel oil accounts for $57 \%$ of the needs for residential homes, with $38 \%$ being provided by wood and $5 \%$ from bottled gas. The costs associated with heating are very high because of the high costs of fuel oil to the community.

A preliminary study performed by Gilbert/Commonwealth, Inc., indicated a need for a power system capable of producing $2100 \mathrm{ke}$ and $15 \mathrm{MMBtu} / \mathrm{hr}$ steam for district heating. Other information available indicates that subbituminous coal from the Jarvis Creek mine could be made available at a cost of approximately $\$ 40 /$ ton. In addition, approximately 400 tons of sawdust and wood wastes and 665 tons of municipal solid waste per year are currently being disposed of in the community.

The lack of a centralized water and sewage treatment facility, regulatory problems with the current landfill, local coal resources of good quality, and a current high cost of electricity made this an ideal community to use for a pilot study of the IMSS. Activities completed in the case study included designing a basic plant layout, preparing material and energy balances, and finally preparing economic projections for implementing an IMSS in the community of Tok. Results of this specific evaluation can be used to determine the relative benefits of IMSS in general.

The backbone of the IMSS used for this case study was an atmospheric fluidized-bed combustor (AFBC) designed to burn local coal as its primary fuel. The AFBC was also designed to burn municipal solid waste, sewage sludge, and secondary fuels such as wood. Waste heat generated in the process was designated for district heating for the community of Tok. An extended 
aeration system was proposed to treat approximately 60,000 gallons per day of sewage and wastewater from the town with the treated wastewater to be discharged into the Tanana River.

An economic analysis was performed on the IMSS based on a 20-year life. A total capital investment of $\$ 18.1$ million was estimated to prepare the facility for production. Based on the current market prices and utility demands for the Tok area, the annual revenue was estimated at $\$ 4.4$ million, while the annual total product cost was estimated at $\$ 4.9$ million.

The internal rate of return (IRR) was determined to be negative $5.11 \%$. This is well below the minimum attractive rate of return (MARR), which was chosen as $18 \%$. To achieve MARR, electricity would have to be sold at a rate of 49.5 cents $/ \mathrm{kWh}$. Also, the breakeven analysis showed that IMSS would not provide a profit within the 20-year project life. Therefore, under current circumstances, it was determined that the IMSS is not an economically attractive alternative for a community the size of Tok.

Sensitivity analysis has shown a system of this nature may be economically attractive for communities with a population of 9100 or greater. Sensitivities were also performed on the price of coal, purchased equipment cost, and the percent utilization of the plant. However, the IMSS would not be economically attractive within the expected ranges of these variables.

District heating, wastewater treatment, and cofiring MSW were added to the basic power generation option to improve the overall economics. Adding the district heating option to the basic electrical generation resulted in a cost increase of approximately $25 \%$ and increased the revenue stream by $37 \%$. The wastewater treatment had an incremental cost increase of $2.9 \%$, with an increase in benefits of $3.6 \%$. The additional cofiring of municipal solid wastes, based on a tipping fee of $\$ 10 /$ ton, showed an increase in revenue of only $0.3 \%$, while the incremental cost increase was approximately $5 \%$. A large part of the costs associated with these options is the development of the infrastructure to support their usage. For example, for the district heating option, most of the added costs are associated with the installation of the piping system to distribute the heat. For those cases where the IMSS would replace an existing system where the infrastructure for district heating is in place, the capital costs would be reduced by over $20 \%$ and the project would generate a positive rate of return.

The IMSS proved to be a technically feasible alternative to provide energy, as well as district heating, waste disposal, and wastewater treatment. Although it is not economically attractive for Tok, it was shown that the larger communities with similar circumstances may benefit from a system of this nature. Therefore, results from this project may provide useful information for future business ventures. 
APPENDIX A

INTEGRATED MUNICIPAL SERVICES SYSTEM RESULTS FROM A CASE STUDY OF TOK, ALASKA 


\title{
Integrated Municipal Services System
}

\section{Final Report}

April 18, 1997

\author{
By: \\ Lanny Schmidt \\ Michelle Kjelden \\ Chris Sprynczynatyk
}




\section{TABLE OF CONTENTS}

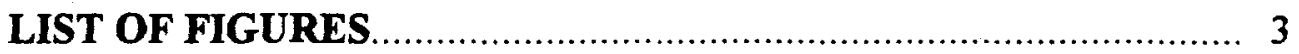

LIST OF TABLES

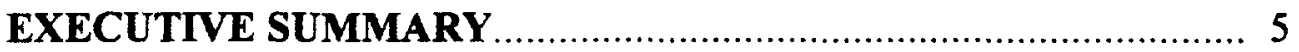

INTRODUCTION

PROCESS SELECTION

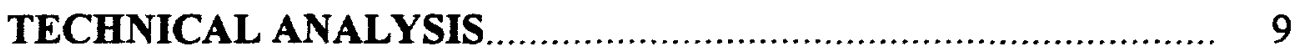

Production Requirements........................................................ 10

Storage and Handling ........................................................... 10

Area 100: Storage and Handling............................................. 10

Power and Heating.................................................................... 13

Area 200: Fuel Combustion.................................................... 15

Area 300: Power Generation............................................... 15

Area 400: District Heating.................................................... 16

Area 500: Particulate Removal............................................. 17

Wastewater Treatment............................................................ 17

Area 600: Wastewater Treatment ........................................ 17

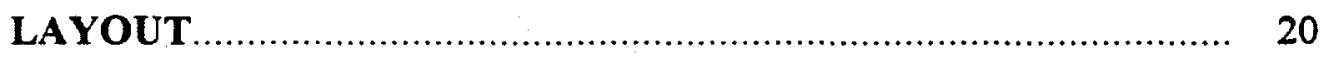

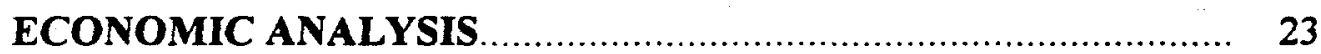

Annual Revenue ............................................................... 23

Total Capital Investment .......................................................... 24

Total Product Costs............................................................. 26

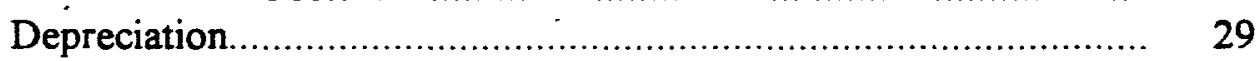

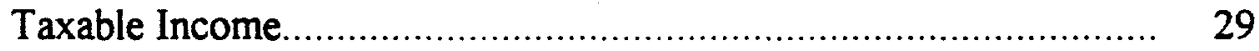

Profitability Analysis .......................................................... 30

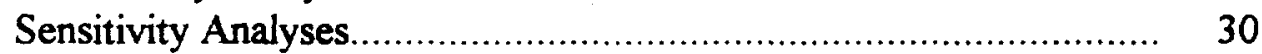

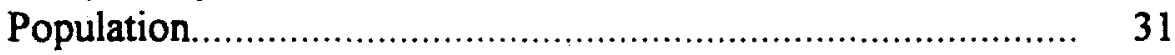

Electricity Rates.......................................................... 32

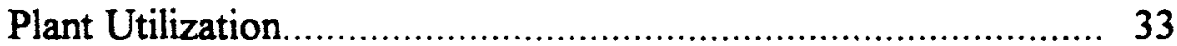

Purchased Equipment Cost................................................... 34

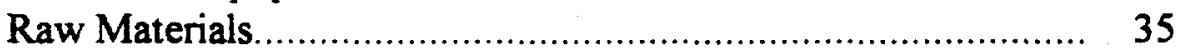

Salvage Value of Buildings.................................................. 35

Breakeven Analysis............................................................ 36 
APPENDIX A: Project Summary ………….................................... 40

APPENDIX B: Quantitative Flow Diagrams..................................... 43

Power Generation and District Heating .................................. 44

Wastewater Treatment.......................................................... 45

APPENDLX C: Area 100: Storage and Handling ............................. 46

APPENDIX D: Area 200: Fuel Combustion..................................... 50

APPENDIX E: Area 300: Power Generation.................................... 53

APPENDIX F: Area 400: District Heating...................................... 55

APPENDIX G: Area 500: Particulate Removal.................................. 57

APPENDIX H: Area 600: Wastewater Treatment............................. 59

APPENDIX I: Stream Summaries.................................................. 63

Power Generation Streams...................................................... 64

Wastewater Treatment Streams............................................. 64

APPENDIX J: Cash Flow Table ................................................... 65

APPENDIX K: Process Flow Calculations........................................... 67

APPENDLX L: Equipment Design Calculations................................. $\quad 79$ 


\section{LIST OF FIGURES}

Figure 1: Qualitative Flow Diagram for Storage and Handling......................... 11

Figure 2: Qualitative Flow Diagram for Power Generation and District Heating. 14

Figure 3: Qualitative Flow Diagram for Wastewater Treatment........................ 18

Figure 4: Plant Layout.............................................................................. 21

Figure 5: Site Layout........................................................................... 22

Figure 6: Direct Costs......................................................................... 25

Figure 7: Indirect Costs...................................................................... 26

Figure 8: Direct Production Costs............................................................... 28

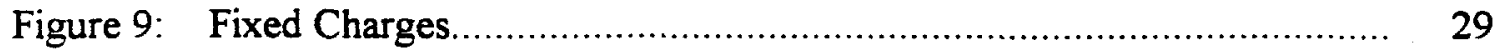

Figure 10: Sensitivity of Population............................................................. 31

Figure 11: Sensitivity of Electricity Rate......................................................... 32

Figure 12: Sensitivity of Plant Utilization....................................................... 33

Figure 13: Sensitivity of Purchased Equipment Cost (PEC) ................................ 34

Figure 14: Sensitivity of Coal Costs................................................................ 35

Figure 15: Payback Period versus Electricity Prices............................................ 36

Figure 16: Quantitative Diagram for Power Generation and District Heating........ 44

Figure 17: Quantitative Diagram for Wastewater Treatment................................ 45 


\section{LIST OF TABLES}

Table 1: Area 100: Storage and Handling Equipment................................... 12

Table 2: Area 200: Fuel Combustion Equipment........................................... 15

Table 3: Area 300: Power Generation Equipment......................................... 16

Table 4: Area 400: District Heating Equipment.............................................. 16

Table 5: Area 500: Particulate Removal Equipment........................................ 17

Table 6: Area 600: Wastewater Treatment Equipment..................................... 19

Table 7: Breakdown of Annual Revenue...................................................... 23

Table 8: Total Capital Investment.............................................................. 24

Table 9: Total Production Costs....................................................................... 27

Table 10: Area 100: Storage and Handling Equipment.................................... 48

Table 11: Area 200: Fuel Combustion Equipment......................................... 52

Table 12: Area 300: Power Generation Equipment.......................................... 54

Table 13: Area 400: District Heating Equipment........................................... 56

Table 14: Area 500: Particulate Removal Equipment...................................... 58

Table 15: Area 600: Wastewater Treatment Equipment.................................... 62

Table 16: Power Generation Streams......................................................... 64

Table 17: Wastewater Treatment Streams.................................................... 64

Table 18: Cash Flow Table..................................................................... 66 


\section{EXECUTIVE SUMMARY}

Tok, Alaska is a small, remote community that faces increasing energy costs and pollution problems. As a possible solution, Alaska Power and Telephone Company (AP\&T) is proposing an Integrated Municipal Services System (IMSS) that seeks to provide a reliable, affordable, and environmentally sound source of energy. The IMSS will provide power, district heating, solid waste disposal, and wastewater treatment for the community.

Coal, supplied locally, will be burned in an atmospheric fluidized bed combustor (AFBC) to generate power. The AFBC will also burn municipal solid waste (MSW), sewage sludge, and secondary fuels (wood). Waste heat generated in the process will be used to provide district heating for the community of Tok. It is estimated 19,000 tons of coal per year will be needed to supply 15.1 million kilowatt hours $(\mathrm{kWh})$ of electricity per year and 360 million BTU per day for district heating. ${ }^{2}$ An extended aeration system will be used to treat approximately 60,000 gallons per day of sewage and wastewater from the town. The treated wastewater will be discharged into the Tanana River.

An economic analysis was performed on the IMSS based on a 20 year project life. A total capital investment of $\$ 18.1$ million is required to prepare the facility for production. Based on the current market prices and utility demands for the Tok area, the annual revenue is estimated at $\$ 4.4$ million while the annual total product cost is estimated at $\$ 4.9$ million.

The internal rate of return (IRR) was determined to be negative 5.11 percent. This is well below the minimum attractive rate of return (MARR), which was chosen as 18 percent. To achieve MARR, electricity would have to be sold at a rate of 49.5 cents $/ \mathrm{kWh}$ compared to the current price of 20.8 cents $/ \mathrm{kWh}$. Also, the breakeven analysis showed the IMSS would not provide a profit within the 20 year project life. Therefore, under current circumstances, it was determined that the IMSS is not an economically attractive alternative at this point. 
Sensitivity analysis has shown a system of this nature may be economically attractive for communities with a population of 9100 or greater. Sensitivities were also performed on the price of coal, purchased equipment cost, and the percent utilization of the plant. However, the IMSS would not be economically attractive within the expected ranges of these variables.

The IMSS proved to be a technically feasible alternative to provide energy, as well as district heating, waste disposal, and wastewater treatment. Although it is not economically attractive for Tok, it was shown that larger communities with similar circumstances may benefit from a system of this nature. Therefore, results form this project may provide useful information for future business ventures. 


\section{INTRODUCTION}

Many rural communities and third world countries throughout the world are faced with extremely expensive electricity prices in comparison with more developed, industrialized areas of the United States. The greater expense is due in large part to high fuel transportation costs and the lack of economies of scale. High electricity rates are not the only problems facing these communities: Inadequate sewage and wastewater treatment facilities lead to illness and pollution of the environment. Waste disposal is increasingly becoming a problem as landfills are quickly becoming filled, and the soil is being subjected to hazardous substances which may leak into the water supply. At the same time, tighter regulations are being placed on air and water emissions and waste disposal. Large sums of money, which small communities lack, will be required to correct current problems.

The Integrated Municipal Services System (IMSS) is being proposed as a possible solution. The IMSS seeks to provide a utility system which integrates power, heating, waste disposal, and wastewater treatment services in an affordable and environmentally friendly manner.

Specifically, the IMSS is aimed at rural communities and third-world countries near abundant coal supplies. Coal will be burned, along with municipal solid waste (MSW) and sewage sludge, in an atmospheric fluidized bed combustor (AFBC) to produce electricity. By utilizing local fuel sources, the transportation costs should be cut considerably. In addition, local wastes will be disposed of in a manner which will minimize pollution of the environment while utilizing the waste's high energy content. The waste heat generated from the AFBC can be used to provide heat to the community. After treating the community's wastewater in an extended aeration system, where solid sludge is removed, the water will be safely discharged into a local water body. 
Tok, Alaska, a rural village of approximately 1,100 residents, has been selected as a potential site for the IMSS. Tok is located near major coal supplies. ${ }^{3}$ However, the town currently relies upon diesel fuel, which is shipped long distances, to generate electricity. Transporting, handling, and storing the diesel fuel is expensive, which increases the cost of electricity. To reduce costs, the State of Alaska subsidizes a large portion of the power cost through the Power Cost Equalization Program (PCE). The PCE fund is expected to be depleted by the year $2000 .^{15}$ Therefore, an alternative means of producing electricity is desired.

IMSS will operate 24 hours a day, 360 days a year. There will be five scheduled down days for maintenance. During these five down days the current diesel system will be used to support the community. The complete project summary is presented in Appendix A. The target start up data for the IMSS is October 1998.

As stated previously, there are many other communities in need of cheap and environmentally safe utility services. Information gathered from the study for Tok can be applied to other communities. Whether or not the IMSS proves to be economically feasible for Tok, it is possible that it could be beneficial for other communities faced with similar circumstances.

\section{PROCESS SELECTION}

Atmospheric fluidized bed combustion will be used to generate electricity from coal. Advantages of burning coal with AFBC are:

- Addition of limestone removes more than $90 \%$ of sulfur pollutants inside the boiler rather than requiring expensive post-combustion devices. ${ }^{14}$

- Reduces the formation of nitrogen oxides by maintaining combustion temperatures at $1550^{\circ} \mathrm{F}^{14}$ 
- Reduces environmental problems associated with MSW and sewage sludge disposal.

- Can be adapted to a variety of sizes without compromising its cost effectiveness. ${ }^{14}$

- Leads to economic development since the money from purchasing the coal remains within the community. It also leads to job creation and infrastructure development. $^{4}$

An extended aeration system, a modification of the activated-sludge process, will be used to treat Tok's wastewater. The specific system chosen, developed by Tipton Environmental International, Inc., is an intermediate size biological wastewater treatment system capable of handling flowrates between 1,000 and 150,000 gallons per day. Currently, Tok produces approximately 60,000 gallons per day of wastewater. ${ }^{6}$ Advantages of using the TEII system are: ${ }^{18}$

- Creates a clear and odor-free effluent.

- Pre-built at the factory and shipped to project site as a compact, self-contained unit.

- Easily expanded for additional capacity.

- Can be installed at almost any location because of its small size.

- Maintenance costs are low.

\section{TECHNICAL ANALYSIS}

The IMSS is broken down into six major processing areas: storage and handling, fuel combustion, power generation, district heating, particulate removal, and wastewater treatment. A discussion of the production requirements and processing areas is given in the following sections. In addition, important equipment design specifications are included in the process discussion with detailed specifications and equipment costs provided in tables within each section. All calculations are shown in Appendix L. 


\section{Production ReQUiREMENTS}

The power generation and heat production equipment were designed based on Tok's average daily electrical demand of 41,370 kilowatt-hours per day (kWh/day) and heating demand of 360 million British Thermal Units (BTU/day). ${ }^{2}$ The existing diesel system will be used to handle peak requirements and any downtime. Figure 16 in Appendix B presents the quantitative flow diagram showing raw material and air requirements needed to meet these demands. The calculations to determine the process flow compositions are shown in Appendix K.

The wastewater treatment system design was based on an average daily flow rate of 60,000 gallons per day and 210 parts per million (ppm) biochemical oxygen demand $\left(\mathrm{BOD}_{5}\right)$. During shutdown the wastewater will accumulate in a storage tank until the system is back on line. The quantitative flow diagram showing the reductions in biochemical oxygen demand $\left(\mathrm{BOD}_{5}\right)$, chemical oxygen demand (COD), phosphorus, and nitrogen achieved in each stage of the aeration process may be viewed in Figure 17 of Appendix B.

\section{STORAGE AND HANDLING}

The storage and handling area stores, prepares, and transports the raw materials before entering the AFBC. Figure 1 shows a complete flow diagram of the storage and handling facilities. The following section briefly describes the storage and handling area. A more thorough description can be found in Appendix C.

\section{Area 100: Storage and Handling}

The fuel used to generate power and heating consists of coal, municipal solid waste (MSW), wood, and sludge. These raw materials remain in the storage and handling area until they are needed as fuel. Before the raw materials are burned in the atmospheric 
Figure 1: Qualitative Flow Diagram Storage and Handling (Area 100)

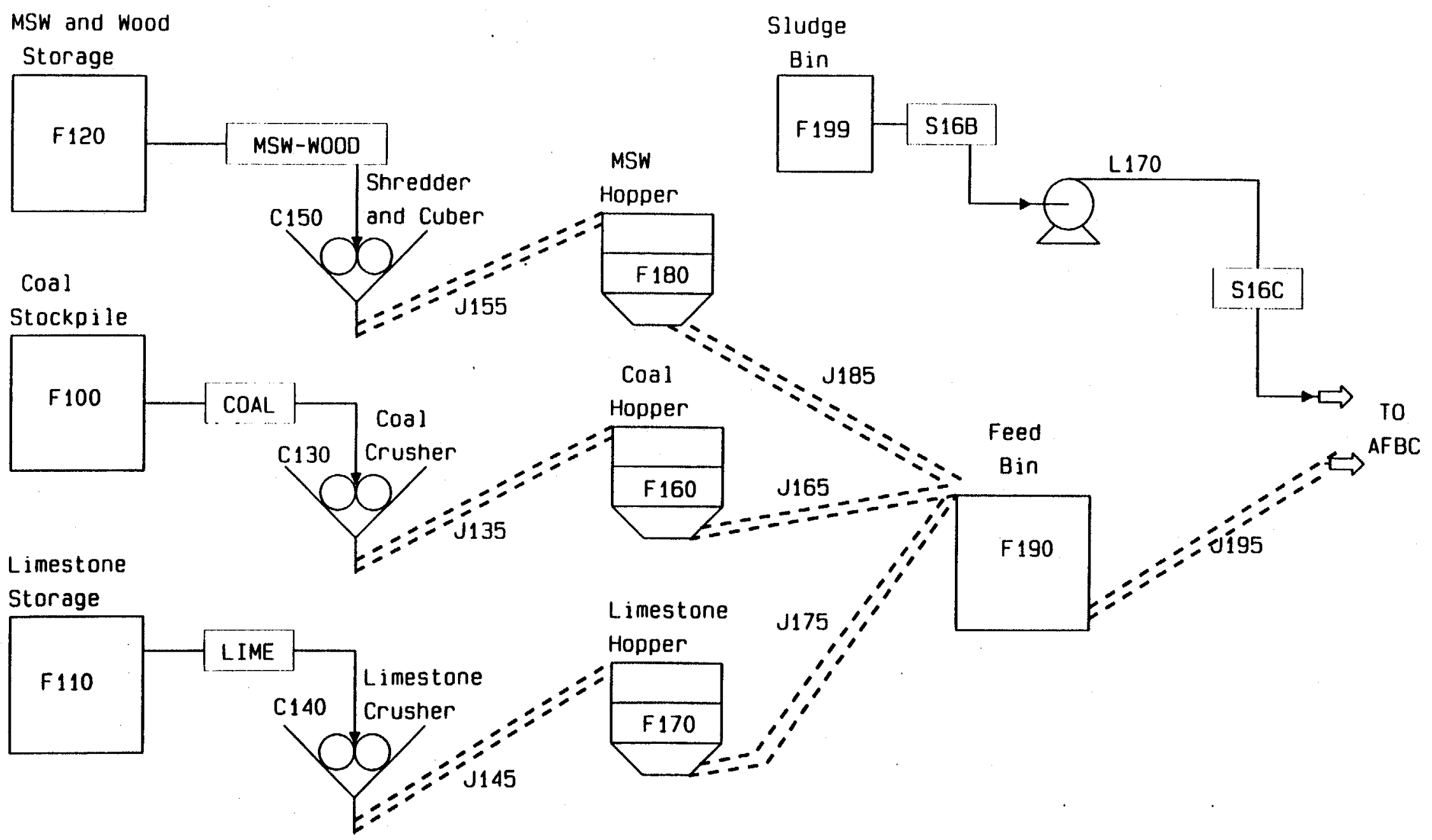


fluidized bed combustor (AFBC), they must be reduced to a suitable size for transportation and fluidization. Jaw crushers will be used for size reduction of the coal and limestone. The MSW will first be shredded and then cubed to a one inch size. After the raw materials are reduced to the required sizes, they are transported to separate hoppers, fed into the feed bin, and finally sent to the AFBC.

Table 1 presents the equipment design specifications and costs for the storage and handling area of the plant.

Table 1: Area 100: Storage and Handling Equipment

\begin{tabular}{|c|c|c|c|c|}
\hline Item No. & Description & Dimensions & Material & Cost \\
\hline & Payloader & 18 feet $^{3}$ capacity & & $\$ 20,000$ \\
\hline & Fork lift & $3000 \mathrm{lb}$ capacity & & $\$ 25,000$ \\
\hline $\mathrm{C} 130$ & Coal jaw crusher & $\begin{array}{l}\text { Capacity }=86 \text { ton } / \mathrm{hr} \\
\text { Power }=60 \mathrm{hp}\end{array}$ & Carbon steel & $\$ 74,000$ \\
\hline $\mathrm{J135}$ & $\begin{array}{l}\text { Belt conveyor from coal } \\
\text { crusher to coal hopper }\end{array}$ & $\begin{array}{l}\text { Width }=3 \text { feet } \\
\text { Length }=100 \text { feet }\end{array}$ & Rubber belt & $\$ 63,000$ \\
\hline$\overline{\mathrm{Cl} 40}$ & Limestone jaw crusher & $\begin{array}{l}\text { Capacity }=20 \text { ton } / \mathrm{hr} \\
\text { Power }=25 \mathrm{hp}\end{array}$ & Carbon steel & $\$ 18,000$ \\
\hline$\sqrt{145}$ & $\begin{array}{l}\text { Belt conveyor from limestone } \\
\text { crusher to } \\
\text { limestone hopper }\end{array}$ & $\begin{array}{l}\text { Width }=2 \text { feet } \\
\text { Length }=100 \text { feet }\end{array}$ & Rubber belt & $\$ 48,000$ \\
\hline \multirow[t]{2}{*}{ C150 } & \multirow[t]{2}{*}{$\begin{array}{l}\text { MSW and wood shredder } \\
\text { and cuber }\end{array}$} & \begin{tabular}{|l|} 
Shredder \\
Capacity $=2000 \mathrm{lb} / \mathrm{hr}$ \\
Power $=10 \mathrm{hp}$ \\
\end{tabular} & Carbon steel & $\$ 41,000$ \\
\hline & & \begin{tabular}{|l|} 
Cuber \\
Capacity $=2000 \mathrm{lb} / \mathrm{hr}$ \\
Cube size $=1 \mathrm{inch}$ \\
\end{tabular} & Carbon steel & $\$ 89,000$ \\
\hline$J 155$ & $\begin{array}{l}\text { Conveyor from cuber to } \\
\text { MSW and wood hopper }\end{array}$ & $\begin{array}{l}\begin{array}{l}\text { Width }=2 \text { feet } \\
\text { Length }=100 \text { feet }\end{array} \\
\end{array}$ & Rubber belt & $\$ 48,000$ \\
\hline F160 & $\begin{array}{l}\text { Coal hopper to store one } \\
\text { day's supply of crushed } \\
\text { coal }\end{array}$ & $\begin{array}{l}\text { Height }=12 \text { feet } \\
\text { Width }=13 \text { feet } \\
\text { Length }=13 \text { feet }\end{array}$ & Carbon steel & $\$ 8,000$ \\
\hline$J 165$ & $\begin{array}{l}\text { Screw conveyor from coal } \\
\text { hopper to feed } \\
\text { hopper }\end{array}$ & $\begin{array}{l}\text { Capacity }=3 \text { ton } / \mathrm{hr} \\
\text { Diameter }=1.5 \text { feet } \\
\text { Length }=12 \text { feet } \\
0-15.9 \mathrm{rmm}\end{array}$ & Plate steel & $\$ 9,000$ \\
\hline
\end{tabular}




\begin{tabular}{|c|c|c|c|c|}
\hline Item No. & Description & Dimensions & Material & Cost \\
\hline$F 170$ & $\begin{array}{l}\text { Limestone hopper to store } \\
\text { two day's supply of crushed } \\
\text { limestone }\end{array}$ & $\begin{array}{l}\text { Height }=5 \text { feet } \\
\text { Width }=5 \text { feet } \\
\text { Length }=5 \text { feet }\end{array}$ & Carbon steel & 500 \\
\hline$\longdiv { J 1 7 5 }$ & $\begin{array}{l}\text { Screw conveyor from } \\
\text { limestone hopper } \\
\text { to feed hopper }\end{array}$ & $\begin{array}{l}\text { Capacity }=3 \text { ton } / \mathrm{hr} \\
\text { Diameter }=1.5 \text { feet } \\
\text { Length }=5 \text { feet } \\
0.15 .9 \mathrm{fpm} \\
\end{array}$ & Carbon steel & $\$ 5,000$ \\
\hline F180 & $\begin{array}{l}\text { MSW and wood hopper to } \\
\text { store two day's supply of } \\
\text { MSW and wood }\end{array}$ & $\begin{array}{l}\text { Height }=11 \text { feet } \\
\text { Width }=10 \text { feet } \\
\text { Length = } 10 \text { feet }\end{array}$ & Carbon steel & $\$ 4,000$ \\
\hline$J 185$ & $\begin{array}{l}\text { Screw conveyor from MSW } \\
\text { and wood hopper to feed } \\
\text { hopper }\end{array}$ & $\begin{array}{l}\text { Capacity }=3 \text { ton } / \mathrm{hr} \\
\text { Diameter }=1.5 \text { feet } \\
\text { Length }=12 \text { feet } \\
0-15.9 \mathrm{rpm} \\
\end{array}$ & Plate steel & $\$ 9,000$ \\
\hline F190 & $\begin{array}{l}\text { Feed hopper to store one } \\
\text { day's supply of fuel and } \\
\text { limestone }\end{array}$ & $\begin{array}{l}\text { Height }=13 \text { feet } \\
\text { Width }=14 \text { feet } \\
\text { Length }=14 \text { feet }\end{array}$ & Carbon steel & $\begin{array}{ll}10,000 \\
\end{array}$ \\
\hline $\mathrm{J} 195$ & $\begin{array}{l}\text { Screw conveyor from feed } \\
\text { hopper to AFBC }\end{array}$ & $\begin{array}{l}\text { Capacity }=3 \text { ton } / \mathrm{hr} \\
\text { Diameter }=1.5 \mathrm{feet} \\
\text { Length }=20 \text { feet } \\
0-15.9 \mathrm{rpm}\end{array}$ & Plate steel & $\$ 12,000$ \\
\hline F199 & $\begin{array}{l}\text { Wastewater sludge bin for } \\
\text { three day's capacity }\end{array}$ & $\begin{array}{l}\text { Height }=4 \text { feet } \\
\text { Diameter }=4 \text { feet }\end{array}$ & Carbon steel & \$ 3,000 \\
\hline Total & & & & $\$ 486,500$ \\
\hline
\end{tabular}

\section{Power AND Heating}

The power and heating section contains the equipment necessary to convert the fuel into energy that is used to supply electricity and district heating. Also, particulate removal operations are included to ensure that all emission regulations are met. Flyash will be collected in bins until it is transported to the local landfill. A complete flow diagram of the power and heating section is shown in Figure 2. General operations of each area within the power and heating section are explained in the following section. A more detailed description of Area 200 (fuel combustion), Area 300 (power generation), Area 400 (district heating), and Area 500 (particulate removal) is given in Appendices D, E, F, and G, respectively. 
Figure 2: Qualitative Flow Diagram

Power Generation and District Heating

Area 500

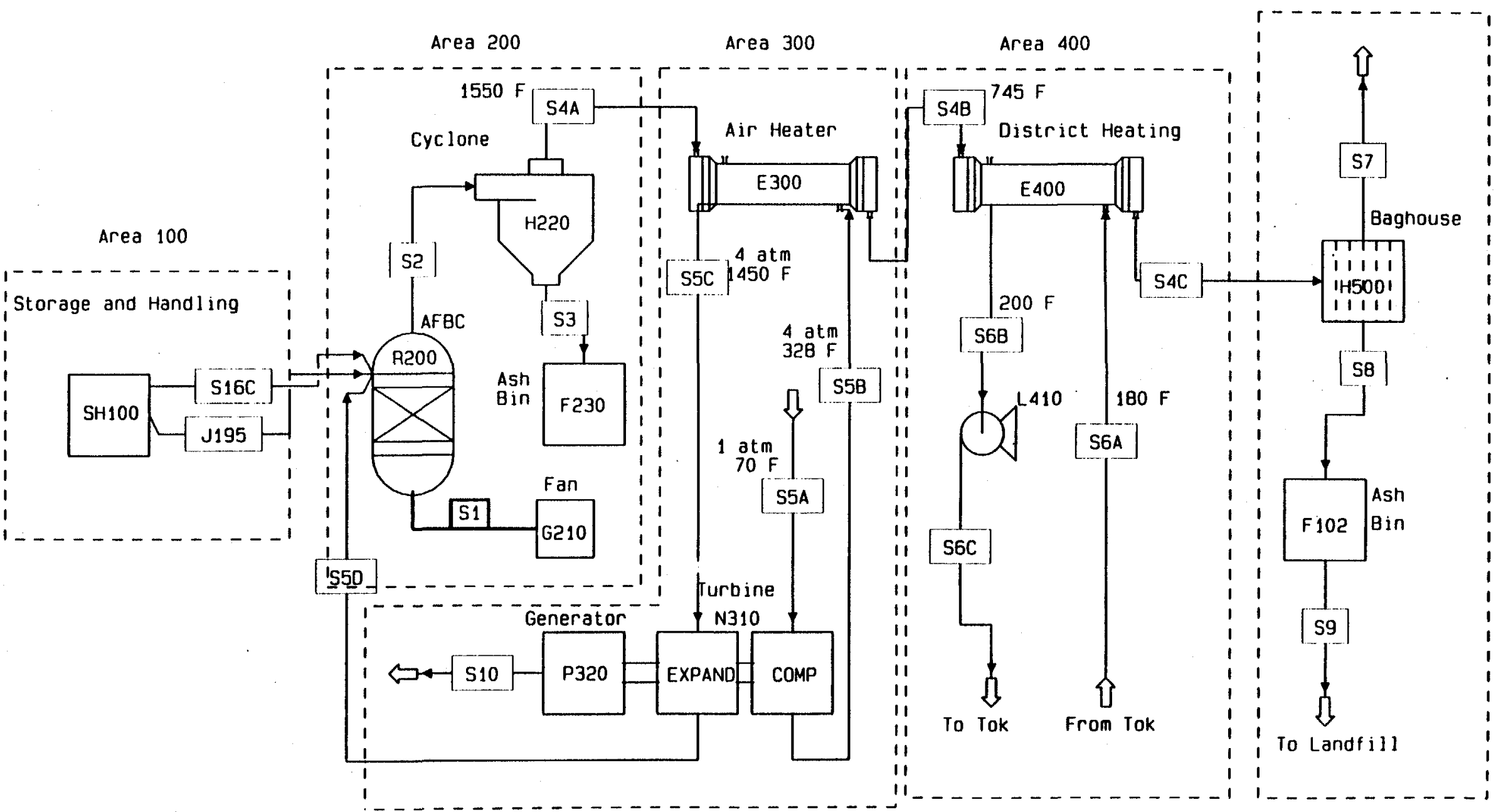




\section{Area 200: Fuel Combustion}

Fuel combusts with air in the atmospheric fluidized bed combustor (AFBC) to generate heat. The AFBC was designed to operate at $1550^{\circ} \mathrm{F}$ to minimize the formation of nitrogen oxides. ${ }^{15}$ Limestone is also burned in the AFBC to reduce the sulfur dioxide emissions below EPA regulations. A cyclone, located immediately after the AFBC, removes 91 percent of the flyash from the flue gas to prevent accumulation in the air heater.

Table 2 lists all the equipment contained in the fuel combustion area. The dimensions, materials of construction, and the cost of each piece of equipment is also given in the table.

Table 2: Area 200: Fuel Combustion Equipment

\begin{tabular}{|l|l|l|l|l|}
\hline Item No. & Description & Dimensions & Material & Cost \\
\hline R200 & $\begin{array}{l}\text { Atmospheric Fluidized Bed } \\
\text { Combustor }\end{array}$ & $\begin{array}{l}\text { Height }=17 \text { feet } \\
\text { Width }=14 \text { feet } \\
\text { Length }=14 \text { feet }\end{array}$ & $\begin{array}{l}\text { Carbon steel } \\
\text { with } 8 \text { inches } \\
\text { of insulating } \\
\text { refractory }\end{array}$ & $\$ 545,000$ \\
\hline G210 & $\begin{array}{l}\text { Centrifugal fan to supply } \\
\text { atmospheric air to AFBC }\end{array}$ & $\begin{array}{l}\text { l68,000 lb/day air } \\
\text { Power }=2 \text { hp }\end{array}$ & Carbon steel & $\$ 2,000$ \\
\hline H220 & $\begin{array}{l}\text { Cyclone to remove flyash } \\
\text { from the fluegas }\end{array}$ & $\begin{array}{l}\text { Diameter }=1.56 \text { feet } \\
\text { Height }=3.2 \text { feet }\end{array}$ & $\begin{array}{l}\text { Carbon steel } \\
\text { with 4 inches } \\
\text { of insulating } \\
\text { refractory }\end{array}$ & $\$ 30,000$ \\
\hline F230 & $\begin{array}{l}\text { Storage bin for flyash from } \\
\text { cyclone (2 day capacity) }\end{array}$ & $\begin{array}{l}\text { Height }=7 \text { feet } \\
\text { Width }=7 \text { feet } \\
\text { Length }=7 \text { feet }\end{array}$ & Carbon steel & $\$ 1,000$ \\
\hline Total & & & & $\$ 578,000$ \\
\hline
\end{tabular}

\section{Area 300: Power Generation}

Hot flue gas from the cyclone enters the air heater and heats air from the gas turbine compressor from $328^{\circ} \mathrm{F}$ to $1440^{\circ} \mathrm{F}$. The pressurized hot air leaving the air heater at $1440^{\circ} \mathrm{F}$ and four atmospheres is reduced to $1280^{\circ} \mathrm{F}$ and one atmosphere by expansion through the turbine. The generator converts the mechanical work created by the hot gas expansion into electricity. 
Table 3 lists all the equipment contained in the power generation area. The dimensions, materials of construction, and the cost of each piece of equipment is also given in the table.

Table 3: Area 300: Power Generation Equipment

\begin{tabular}{|l|l|l|l|c|}
\hline Item No. & Description & Dimensions & Material & Cost \\
\hline E300 & $\begin{array}{l}\text { Air heater to heat air from } \\
\text { turbine compressor }\end{array}$ & $\begin{array}{l}\text { Heat transfer area }= \\
674 \text { feet }^{2}\end{array}$ & Stainless steel & $\$ 31,000$ \\
\hline N310 & Hot Air Gas Turbine & $1,975,000 \mathrm{lb} /$ day air & Carbon steel & $\$ 867,000$ \\
\hline P320 & $\begin{array}{l}\text { Generator to convert mechanical } \\
\text { work to } \\
\text { electricity }\end{array}$ & $41,370 \mathrm{kWh} /$ day & Carbon steel & \\
\hline Total & & & & $\$ 898,000$ \\
\hline
\end{tabular}

\section{Area 400: District Heating}

IMSS utilizes waste heat generated by the process to provide district heating to the community. Hot flue gas from the air heater enters the district heating heat exchanger and heats the water/glycol stream returning from the district. The heated water/glycol stream is then recirculated throughout the community to provide Tok with heat.

Table 4 lists all the equipment contained in the district heating area. The dimensions, materials of construction, and the cost of each piece of equipment is also given in the table.

Table 4: Area 400: District Heating Equipment

\begin{tabular}{|l|l|l|l|c|}
\hline Item No. & Description & Dimensions & Material & Cost \\
\hline E400 & $\begin{array}{l}\text { Heat exchanger for district } \\
\text { heating (water glycol stream) }\end{array}$ & $\begin{array}{l}\text { Heat transfer area }= \\
500 \text { feet }^{2}\end{array}$ & Carbon steel & $\$ 13,000$ \\
\hline L410 & $\begin{array}{l}\text { Pump to circulate water } / \text { glycol } \\
\text { stream through Tok }\end{array}$ & $\begin{array}{l}1776 \mathrm{gal} / \mathrm{min} \\
\text { Power }=109 \mathrm{hp}\end{array}$ & Carbon steel & $\$ 8,000$ \\
\hline Total & & & & $\$ 21,000$ \\
\hline
\end{tabular}




\section{Area 500: Particulate Removal}

Flue gas from the water/glycol heat exchanger enters the baghouse where the flyash removal is completed. Seven pounds of flyash per day is emitted from the stack. This is well below the national standard for ash emissions, which is 29 pounds per day.

Table 5 lists all the equipment contained in the particulate removal area. The dimensions, materials of construction, and the cost of each piece of equipment is also given in the table.

Table 5: Area 500: Particulate Removal Equipment

\begin{tabular}{|l|l|l|l|r|}
\hline Item No. & Description & Dimensions & Material & Cost \\
\hline H500 & $\begin{array}{l}\text { Baghouse to remove final } \\
\text { flyash from flue gas }\end{array}$ & $\begin{array}{l}\text { Compartments }=3 \\
\text { Bags/Compartment }=398\end{array}$ & $\begin{array}{l}\text { Carbon steel } \\
\text { shell Dacron } \\
\text { bags }\end{array}$ & $\$ 544,000$ \\
\hline F510 & $\begin{array}{l}\text { Storage bin for flyash from } \\
\text { baghouse (2 day capacity) }\end{array}$ & $\begin{array}{l}\text { Height = 4 feet } \\
\text { Width = 3 feet } \\
\text { Length = 3 feet }\end{array}$ & Carbon steel & $\$ 150$ \\
\hline Total & & & & $\$ 544,150$ \\
\hline
\end{tabular}

\section{WASTEWATER TREATMENT}

The wastewater treatment system will treat the community's sewage and wastewater so it can be discharged into the Tanana River. Sludge removed from the system will be pumped to the AFBC and burned. A complete flow diagram of the wastewater treatment system is presented in Figure 3. A more detailed description of the equipment is given in Appendix $\mathrm{H}$.

\section{Area 600: Wastewater Treatment}

An extended aeration system will be used to treat 60,000 gallons of wastewater per day. The wastewater will pass through a bar screen to remove all large solids before entering the aeration chamber. Biochemical oxygen demand $\left(\mathrm{BOD}_{5}\right)$ and chemical oxygen demand 


\section{Figure 3: Qualitative Flow Diagram}

Wastewater Treatment System (Area 600)

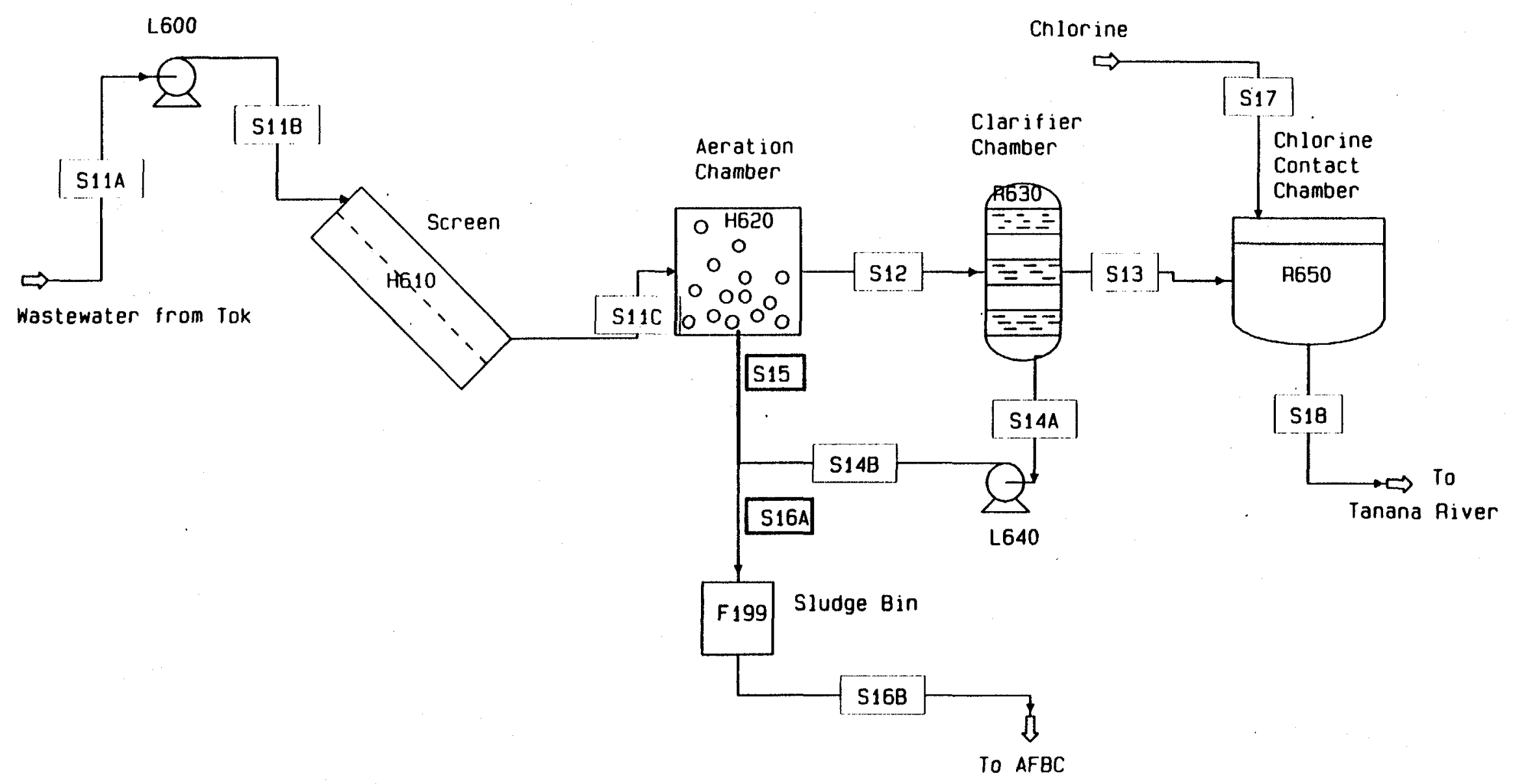


(COD) are reduced in the aeration chamber. The wastewater then enters the clarifier chamber, where solids are allowed to settle out. Approximately one-half of the activated sludge is recycled into the aeration chamber, while the remaining sludge is transported to the sludge bin. Finally, the water leaving the clarifier chamber enters the chlorine contact chamber where remaining bacteria is killed before the water is discharged into the Tanana River.

Table 6 lists all the equipment contained in the wastewater treatment area. The dimensions, materials of construction, and the cost of each piece of equipment is also given in the table.

Table 6: Area 600: Wastewater Treatment Equipment*

\begin{tabular}{|c|c|c|c|}
\hline Item No. & Description & Dimensions & Cost \\
\hline L600 & Pump the water from Tok to plant & $\begin{array}{l}60,000 \text { gal/day } \\
\text { Power = } 1 \mathrm{hp}\end{array}$ & $\$ 2,000$ \\
\hline $\mathrm{H} 610$ & Bar screen to remove large solids & $\begin{array}{l}\text { Bar Spacing }=1 \text { inch } \\
\text { Bar Diameter }=1 / 2 \text { inch }\end{array}$ & $\$ 75,000$ \\
\hline $\mathrm{R} 620$ & $\begin{array}{l}\text { Aeration chamber which controls } \\
\text { oxygen level and reduces } B O D_{5} s \\
\text { and CODs }\end{array}$ & $\begin{array}{l}\text { Volume }=72,000 \text { gallons } \\
\text { Depth:Width }=1.33: 1 \\
\text { Retention Time }=24 \text { hours }\end{array}$ & \\
\hline $\mathrm{R} 630$ & Clarifier chamber to remove solids & $\begin{array}{l}\text { Volume }=11,000 \text { gallons } \\
\text { Retention Time }=4 \text { hours }\end{array}$ & \\
\hline $\mathrm{L} 640$ & $\begin{array}{l}\text { Pump to recirculate activated sludge } \\
\text { from clarifier to aeration chamber }\end{array}$ & 4 inch airlift sludge pump & \\
\hline R650 & $\begin{array}{l}\text { Chlorine contact chamber to kill } \\
\text { bacteria }\end{array}$ & $\begin{array}{l}\text { Volume }=1250 \text { gallons } \\
\text { Retention Time }=30 \mathrm{~min} .\end{array}$ & \\
\hline F660 & $\begin{array}{l}\text { Wastewater storage tank to hold up } \\
\text { to one day's supply of wastewater }\end{array}$ & 72,000 gallon capacity & \\
\hline L670 & Pump the sludge to AFBC & $\begin{array}{l}88 \mathrm{gal} / \text { day } \\
\text { Power }=0.01 \mathrm{hp}\end{array}$ & 300 \\
\hline Total & & & $\$ 77,300$ \\
\hline
\end{tabular}

* All pieces of equipment are constructed of a painted steel 


\section{LAYOUT}

Figure 4 on the following page shows the complete equipment layout of the proposed Integrated Municipal Service System (IMSS), while Figure 5 on page 22 shows an overall site layout. The equipment and buildings were arranged to provide a safe process, easy maintenance, transportation access, and minimize pipe and conveyor lengths.

The storage facilities were all placed close to Glen Highway to facilitate receiving raw materials. Next to the storage facilities is the 4500 square feet pole barn which houses the size reduction equipment. The size reduction equipment was located in a separate building for safety reasons.

The main process building was arranged to minimize pipe and conveyor lengths. The land requirements for the main process building is 175 feet by 125 feet. Both the wastewater treatment and power generation systems may easily be expanded. Future expansion of the power generation system would result in expanding the building to the north to accommodate a second AFBC unit. The wastewater treatment system has a grid like flooring which allows for tanks to be removed and larger ones installed if a larger system is desired. 


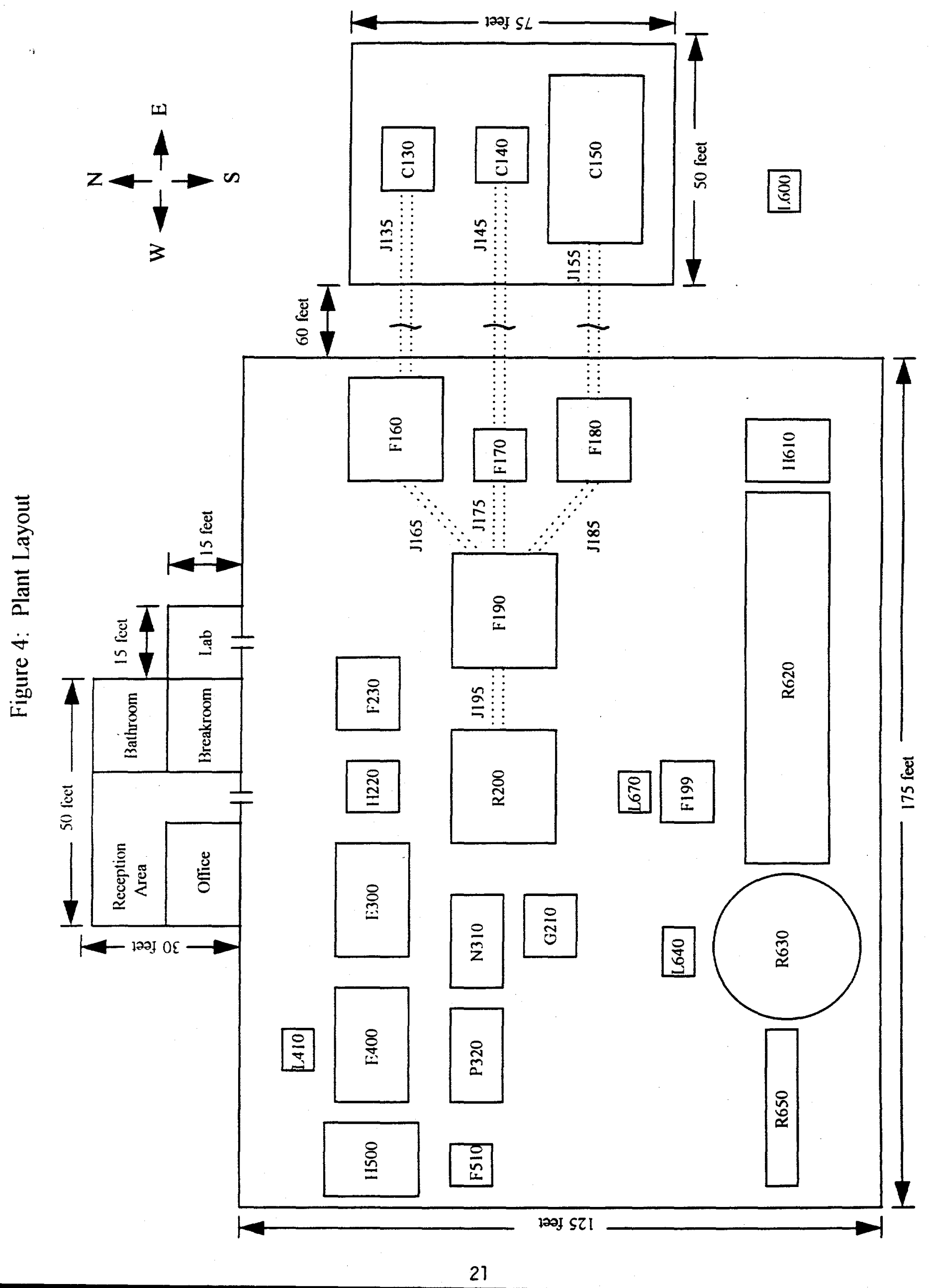




\section{ECONOMIC ANALYSIS}

The economic feasibility of the IMSS is dependent upon the cash flows throughout the life of the project. Table 18 in Appendix J shows the annual cash flow expected for the IMSS over its 20 year projected life. The annual revenue, initial investment, annual production costs, depreciation, and taxable income are discussed in the following sections. In addition, three different analyses were performed to judge the attractiveness of the project. These include a profitability analysis, sensitivity analyses, and a breakeven analysis.

\section{AnNual Revenue}

The annual revenue received by IMSS is the sum of the incomes from the four separate utilities it provides: electricity, district heating, waste disposal, and wastewater treatment. Current market prices and demands for each utility, which were assumed to be constant over the proposed life of the project, were used to calculate the annual revenue. Table 7 below shows the breakdown of demand, price, and revenue for each utility service. The total expected annual sales of the IMSS is $\$ 4.4$ million per year.

Table 7: Breakdown of Annual Revenue

\begin{tabular}{|l|c|c|r|}
\hline \multicolumn{1}{|c|}{ Source of Revenue } & Demand & Price/Unit & Annual Revenue \\
\hline Electricity & $15,100,000 \mathrm{kWh} / \mathrm{yr}^{2}$ & $\$ 0.208 / \mathrm{kWh}^{2}$ & $\$ 3,141,000$ \\
\hline District Heating & 360 million BTU/day $^{2}$ & $\$ 8.75 /$ million BTU $^{12}$ & $\$ 1,150,000$ \\
\hline Waste Disposal & $964 \mathrm{ton} / \mathrm{yr}^{15}$ & $\$ 10 /$ ton $^{15}$ & $\$ 10,000$ \\
\hline Wastewater Treatment & $60,000 \mathrm{gal} /$ day & $\$ 0.0051 / \mathrm{gal}^{12}$ & $\$ 112,000$ \\
\hline Total & & & $\$ 4,413,000$ \\
\hline
\end{tabular}




\section{Total CaPital InVESTMENT}

The total capital investment, which is comprised of fixed-capital investment and working capital, is $\$ 18,067,000$. Fixed capital investment is broken down further into direct costs and indirect costs. Table 8 gives a breakdown of the individual costs which make up the total capital investment.

Table 8: Total Capital Investment

\begin{tabular}{|c|c|c|c|}
\hline Components & $\begin{array}{r}\text { Calculat } \\
\mathbf{X} \%\end{array}$ & $\begin{array}{c}\text { Basis }^{13} \\
\text { of }\end{array}$ & Cost \\
\hline $\begin{array}{l}\text { Direct Costs (DC) } \\
\text { Purchased Equipment }(\mathrm{PEC})^{*} \\
\text { Installation } \\
\text { Instrumentation and Controls } \\
\text { Piping, installed } \\
\text { Piping for district heating }{ }^{2} \\
\text { Electrical, installed } \\
\text { Buildings*.10,11 } \\
\text { Service Facilities \& Yard Improvements } \\
\text { Land }{ }^{* 1} \\
\text { Ethylene Glycol } \\
\text { Total Direct Costs }\end{array}$ & $\begin{array}{r}40 \% \\
18 \% \\
45 \% \\
13 \% \\
70 \%\end{array}$ & $\begin{array}{l}\text { PEC } \\
\text { PEC } \\
\text { PEC } \\
\text { PEC } \\
\text { PEC }\end{array}$ & $\begin{array}{lr}\$ & 2,605,000 \\
\$ & 1,042,000 \\
\$ & 469,000 \\
\$ & 1,172,000 \\
\$ & 2,250,000 \\
\$ & 339,000 \\
\$ & 1,456,000 \\
\$ & 1,823,000 \\
\$ & 5,000 \\
\$ & 76,000 \\
\end{array}$ \\
\hline $\begin{array}{l}\text { Indirect Costs (IDC) } \\
\text { Engineering and Supervision } \\
\text { Construction Expense and Contractor's Fee } \\
\text { Contingency } \\
\text { Total Indirect Costs }\end{array}$ & $\begin{array}{c}8 \% \\
15 \% \\
10 \%\end{array}$ & $\begin{array}{l}\text { DC } \\
\text { DC } \\
\text { FCI }\end{array}$ & $\begin{array}{lr}\$ & 899,000 \\
\$ & 1,685,000 \\
\text { S } 1,536,000 \\
\text { S } & 4,120,000\end{array}$ \\
\hline $\begin{array}{l}\text { Fixed-Capital Investment (FCI) } \\
\text { Working Capital (WC) } \\
\text { Total Capital Investment (TCI) }\end{array}$ & $\begin{array}{r}\mathrm{D} \\
15 \% \\
\mathrm{FC}\end{array}$ & $\begin{array}{l}\mathrm{C} \\
\mathrm{TCI}\end{array}$ & $\begin{array}{l}\$ 15,357,000 \\
\$ 2,710,000 \\
\mathbf{\$ 1 8 , 0 6 7 , 0 0 0}\end{array}$ \\
\hline
\end{tabular}

* indicates costs were calculated using known prices and quantities 
Purchased equipment costs, buildings, land, and ethylene glycol were calculated using cost estimation tables and known prices and quantities: Costs for individual pieces of equipment can be found in previous tables located in the Technical Analysis section. Values from a study done by Gilbert/Commonwealth Inc. ${ }^{2}$ were used to obtain the district heating pipe cost. Ethylene glycol used for district heating was assumed to be a one time cost.

All other costs were estimated as a percentage of the purchased equipment costs, direct costs, fixed capital investment or total capital investment. Extra landscaping will be needed to construct a shelterbelt to obstruct the view of the coal pile from the highway. Therefore, the cost for service facilities and yard improvements was estimated using the highest value within the expected range of values. Also, contingencies were estimated at a slightly higher rate than the most commonly used rate due to the harsh climate in Alaska. The remainder of the costs were estimated using the most common or average percentage rate.

Figure 6 below presents the breakdown of the total direct cost, $\$ 11,237,000$, for the IMSS project.

\section{Direct Costs}

$\$ 11,237,000$

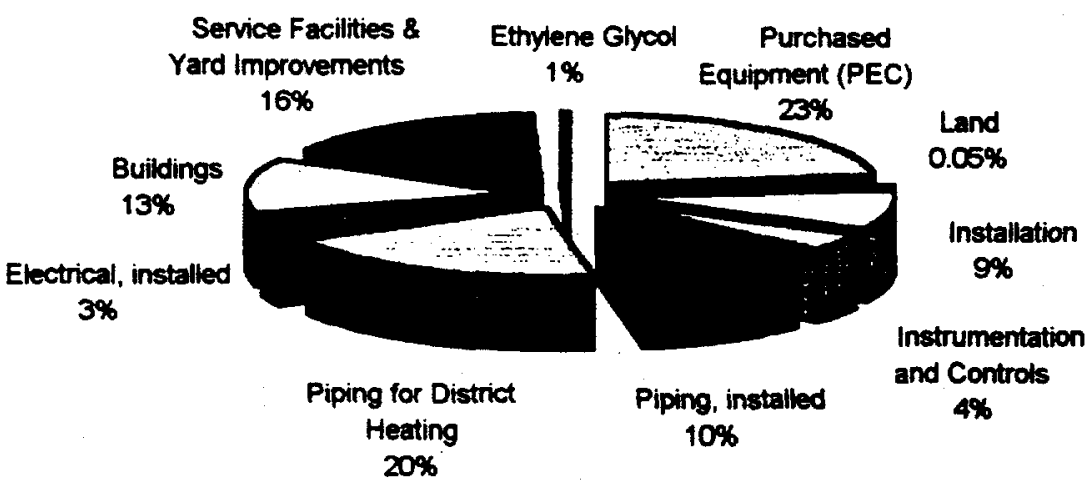

Figure 6: Direct Costs 


\section{Electricity Rates}

Another variable which could have a significant impact on the profitability is the rate charged for electricity. The baseline rate used in the economic analysis was 20.8 cents $/ \mathrm{kWh}$, which is the current price of electricity in Tok. Figure 11 shows the sensitivity of the IMSS to variations in the electricity rate of up to $60 \mathrm{cents} / \mathrm{kWh}$. The MARR would be met at a rate of approximately 49.5 cents $/ \mathrm{kWh}$. Any rate at or above this would make the IMSS an attractive project. However, the rate of electricity has not changed significantly in the past. It seems unlikely that a rate of 49.5 cents $/ \mathrm{kWh}$ will be charged within the next 20 years. At a rate of about 25.5 cents $/ \mathrm{kWh}$ the IMSS would break even.

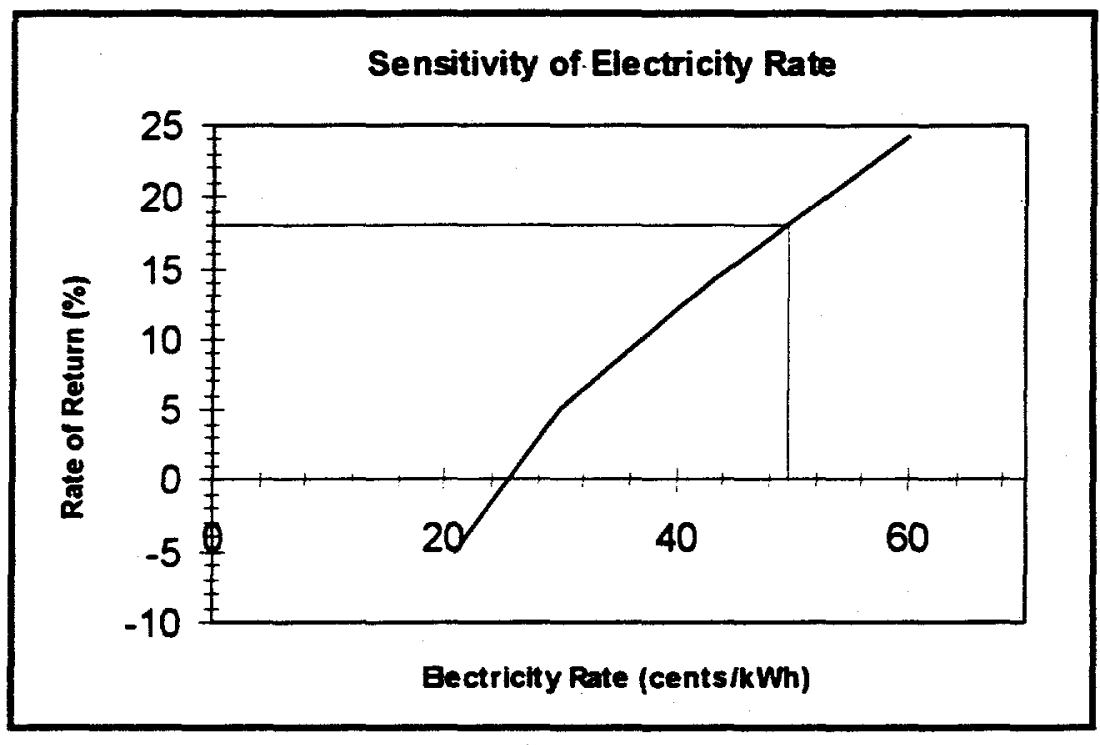

Figure 11: Sensitivity of Electricity Rate 


\section{Plant Utilization}

Plant utilization could change significantly if Tok's utility demands were to change. Since it is likely the plant has been oversized to some degree, a sensitivity analysis on plant utilization was performed by varying it by plus and minus 50 percent. The results of the sensitivity analysis can be seen in Figure 12. The figure indicates that profitability is sensitive to plant utilization. Despite the sensitivity to plant utilization, MARR would not be met operating at 150 percent. The plant will break even at approximately 120 percent utilization.

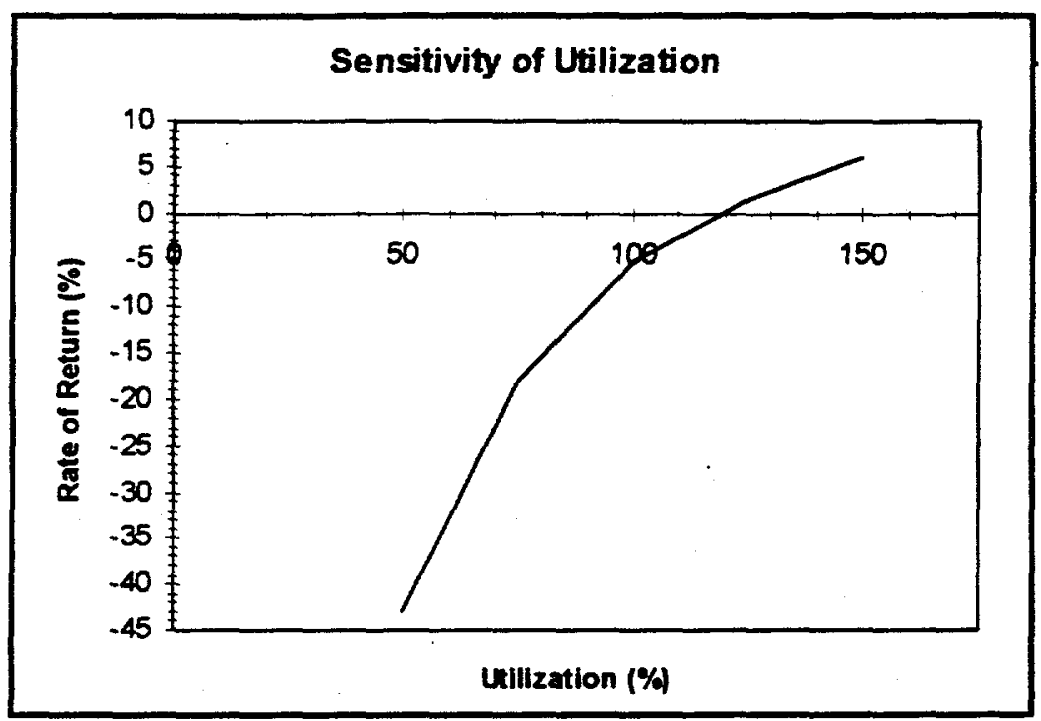

Figure 12: Sensitivity of Plant Utilization 


\section{Purchased Equipment Cost}

Purchased equipment cost is a major component of the total fixed-capital investment. However, the prices for many pieces of equipment had to be estimated from graphs and tables found in the literature. Other price estimates were obtained from vendors. The sensitivity analysis, in which the PEC was varied by plus and minus 30 percent, is shown in Figure 13. As the figure illustrates, the profitability is sensitive to the PEC. However, over the expected degree of variation, the project will not be attractive. If the PEC estimate was off by minus 23 percent, the IMSS project would break even.

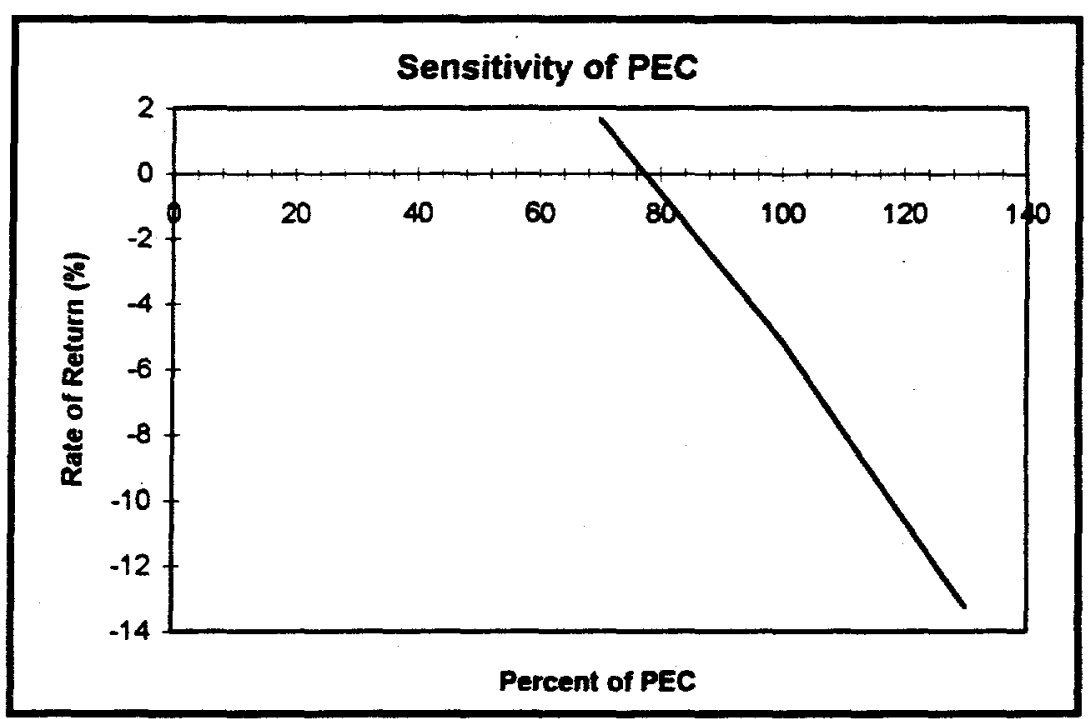

Figure 13: Sensitivity of Purchased Equipment Cost (PEC) 


\section{$\underline{\text { Raw Materials Cost }}$}

The cost of raw materials could vary over the life of the project depending on the supply available, advances in mining techniques, etc. Since the cost of coal dominates the total raw materials cost, it alone was used in the sensitivity analysis shown in Figure 14. The current price of coal is $\$ 30$ per ton, which includes the cost of delivery. Cheaper coal prices would not make the project attractive. IMSS would break even at a cost of approximately $\$ 15$ per ton.

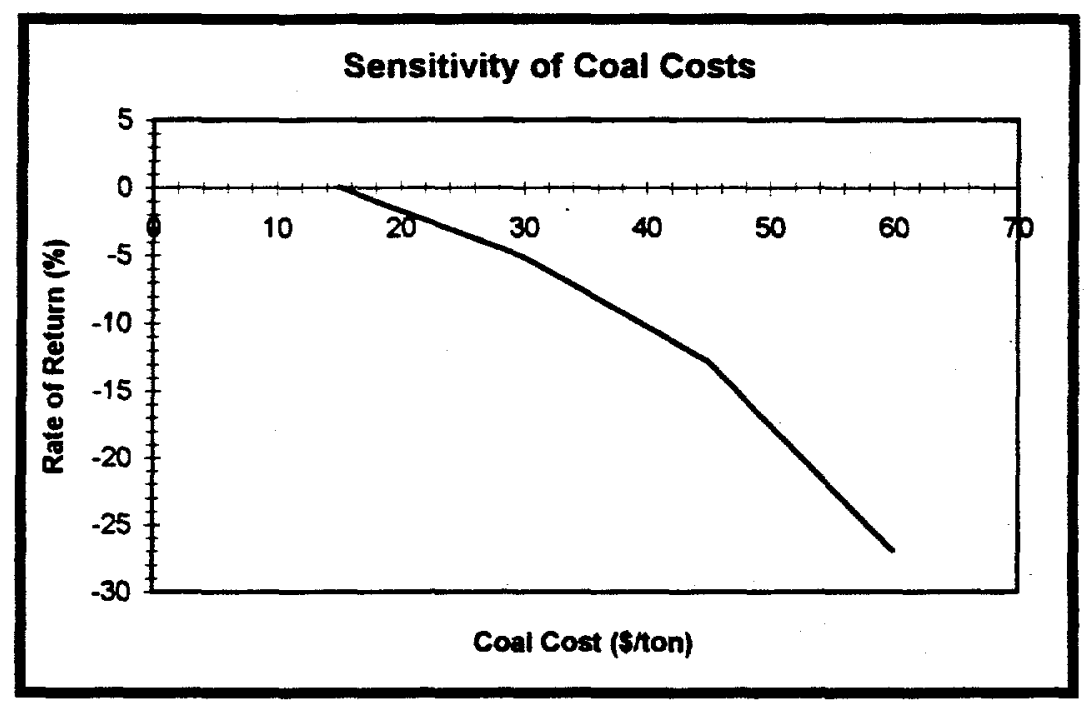

Figure 14: Sensitivity of Coal Costs

\section{Salvage Value of Buildings}

Since the buildings will not be fully depreciated, it is assumed they will have a salvage value at the end of the 20 years. In the economic analysis of the IMSS, it was assumed there was a 20 percent salvage value on the buildings. A sensitivity analysis was performed varying the salvage value from zero to 50 percent. It was observed the rate of return would change by less than one percent. Thus, the salvage value was found to be an insensitive variable, and great concern should not be placed on trying to improve on this assumption. 


\section{BREAKEVEN ANALYSIS}

The point at which the plant operates at a zero percent rate of return is called the breakeven point. Since the main goal of the IMSS is to make a profit while providing Tok with a more affordable source of energy, electricity prices dictate the economic feasibility of this project. At the current market price (20.8 cents $/ \mathrm{kWh}$ ), the IMSS does not breakeven throughout the life of the project. Electricity prices would have to reach 21.3 cents $/ \mathrm{kWh}$ to breakeven at the end of the project. To attain MARR, the electricity prices would need to be $49.5 \mathrm{cents} / \mathrm{kWh}$.

Figure 15 illustrates the payback period as a function of the electricity prices. Payback period is the time it takes to recover the initial investment. Many companies use payback period as an aid in making economic decisions. Currently the payback time exceeds the life of the project. At the breakeven point and at MARR, the payback time is 20 years and 5.3 years, respectively.

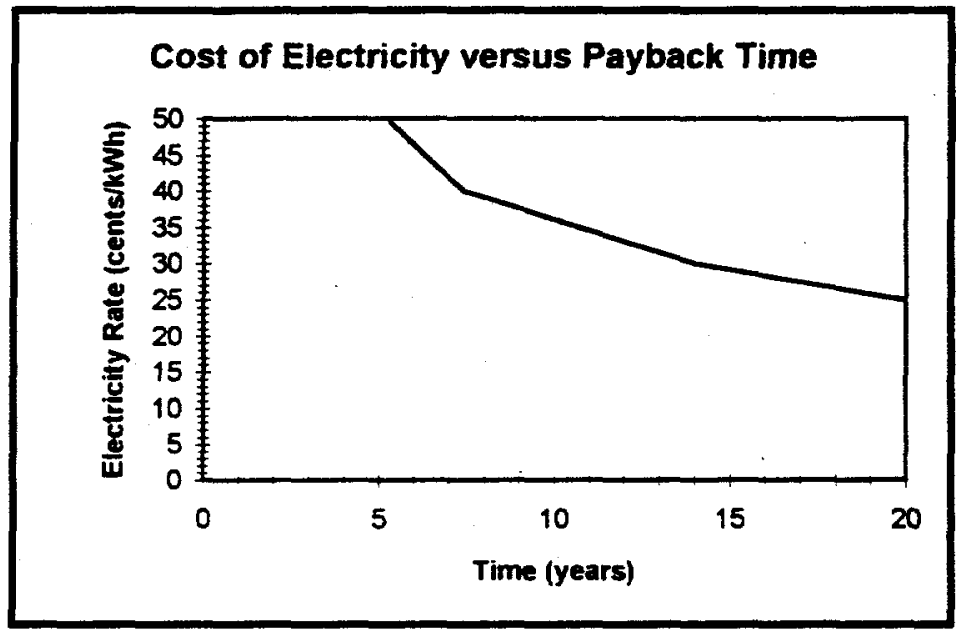

Figure 15: Payback Period for Different Electricity Rates 


\section{CONCLUSIONS AND RECOMMENDATIONS}

The internal rate of return (IRR) is a negative 5.11 percent, which is well below the desired 18 percent minimum attractive rate of retum (MARR). Therefore, the IMSS project is not economically attractive for Tok, Alaska.

In addition, sensitivity analyses conducted on the purchased equipment costs, percent utilization, and price of coal showed the IMSS would not be economically attractive within their expected ranges. A further sensitivity analysis indicated electricity would have to be sold at a rate of 49.5 cents $/ \mathrm{kWh}$ to achieve MARR. However, unless unforeseen circumstances arise that lead to a drastic increase in electricity rates, it is expected a rate will be maintained well below 49.5 cents $/ \mathrm{kWh}$. A final sensitivity analysis on the population has shown the IMSS or a similar system may be economically attractive for communities of 9100 people or greater.

The IMSS proved to be a technically feasible alternative to provide energy, as well as district heating, waste disposal, and wastewater treatment. Although it is not economically attractive for Tok, it was shown that larger communities with similar circumstances may benefit from a system of this nature. Therefore, results from this project may provide useful information for future business ventures. 


\section{REFERENCES}

1. "A World Wide Real Estate," http://awrem.com, 4/1/97.

2. "Analysis of Load Data and Preliminary Sizing of Coal Based Power Plant for Tok, Alaska," Prepared for the Energy \& Environmental Research Center by Gilbert/ Commonwealth, Inc., Reading, Pennsylvania, 1995.

3. "Community of Tok: Community Profile, Facilities, and U.S. Census," http://alaskan. com/cgi-bin/showcity.pl, 1/23/97.

4. Mann, Michael, Energy and Environmental Research Center, January 24, 1997.

5. Mann, Michael D., "Influence of Fuel Properties," Proceedings of Council of Industrial Boiler Owners, Fluid Bed IX Conference, Dec. 6-8, 1993.

6. Metcalf \& Eddy, Inc. (Tchobanoglous, G.; and Burton, F. L., revisors), "Wastewater Engineering, Treatment, Disposal, and Reuse," 3rd ed., McGraw-Hill, New York, 1991.

7. Newman, Donald G., "Engineering Economic Analysis," 6th ed., Enginnering Press, San Jose, California, 1996.

8. Perry, Robert H., and Green, Don, "Perry's Chemical Engineers' Handbook," 6th ed., McGraw-Hill, New York, 1984.

9. Perry, Robert H., and Chilton, Cecil H., "Chemical Engineer's Handbook," 5th ed., McGraw-Hill, New York, 1973.

10. Personal Communication, Beltline Construction, Fairbanks, AK, "Price quotes for polebarns," 1997.

11. Personal Communication, ENSTAR Construction, Fairbanks, AK, "Price quotes for office space, laboratory space and plant facilities," 1997.

12. Personal Communication, Fairbanks Municipal Utilities, Fairbanks, AK, "Price quotes for district heating and wastewater treatment," 1997.

13. Peters, Max S., and Timmerhaus, Klaus D., "Plant Design and Economics for Chemical Engineers," 4th ed., McGraw-Hill, New York, 1991.

14. Phillips Jr., Norman L., and Bonk, Donald L., "Doyon Limited Project - Reducing an Alaskan Village's Oil Dependence," http://www.doe.gov/html/fe/mcgrath.html, $1 / 18 / 97$. 
15. Phillips Jr., Norman L., and DeLallo Jr., Michael R., "AFBC Power Systems for Rural Villages," Proceedings from Alaska Native, American Indian, and Native Hawaiian Remote-Site Power Generation Workshop: Transferring the Alaskan Experience, EERC Publication No. 96-EERC-02-01, 1995.

16. Smith, J. M., Van Ness, H. C., and Abbott, M. M., "Introduction to Chemical Engineering Thermodynamics," 5th ed., McGraw-Hill, New York, 1996.

17. "T0963 List by Vendor," http://www.state.nj.us/infobank/noa/t0963d.htm, 3/26/97.

18. Tipton Environmental International, Inc., "The Wastewater Treatment Industry," http://www.tipton.org/wwts-tei.htm, 3/13/96.

19. Tipton, Fred D. (President), Proposal for TEII Wastewater Treatment Systems, Tipton Environmental International, Inc., January 29, 1997.

20. Weston, Kenneth C., "Energy Conversion," West Publishing, St. Paul, MN, 1992. 
APPENDIX A: Project Summary 


\section{ProjeCt SuMmary}

\section{Products}

- 15.1 million $\mathrm{kWh} / \mathrm{yr}$ of electricity will be produced to support the Tok community

- Electrical growth for the next ten years is estimated at two percent producing a demand of 18.9 million $\mathrm{kWh} / \mathrm{yr}$

\section{Raw Materials}

- 19,000 tons per year of Jarvis Creek sub-bituminous coal

- Jarvis Creek Coal has an ash content of $9 \%$ and an average sulfur content of $1 \%$

- 910 tons per year of limestone will be used to reduce the sulfur emissions

- 48 gallons per year of chlorine for wastewater treatment

\section{By Products}

- Waste heat will be used to provide district heating

- Fly ash may be sold for building materials, road construction, or a soil conditioner

- 1,400 tons per year of fly ash will be produced

\section{Plant Process}

- Atmospheric fluidized bed combustion for power generation using a hot air gas turbine

- Wastewater treatment using an extended aeration system

\section{Waste Disposal}

- The sludge from the wastewater treatment and municipal solid waste will be burned in the fluidized bed combustion system

- Remaining fly ash will be delivered to a landfill 


\section{Plant Information}

- The plant location is Tok, Alaska

- IMSS will operate 24 hours a day, 360 days a year, 5 days per year for maintenance

- Electricity, wastewater treatment, and heat is provided by the IMSS

- The coal and limestone will be shipped in 50 ton capacity trucks

- Existing diesel system is used for increasing power demands

- The start up date will be October, 1998

- Power and wastewater treatment systems are easily expandable for future growth

\section{Economics}

- IMSS has an internal rate of return of $-5.11 \%$

- MARR was chosen as $18 \%$

- Total Capital Investment is $\$ 18,067,000$

- Total Product Costs are $\$ 4,859,000$

- MACRS was used as the depreciation method

- To obtain MARR electricity costs would have to be 49.5 cents $/ \mathrm{kWh}$

- IMSS would become economically attractive for communities with a population larger than 9100 


\section{APPENDIX B: Quantitative Flow Diagrams}


Figure 16: Quantitative Flow Diagram for Power Generation and District Heating

Basis: One operating day

Unit designed to produce 41,370 kilowatt-hours per day of electricity and 360 million BTU per day of district heating

\section{Raw Materials \\ Processing \\ Products}

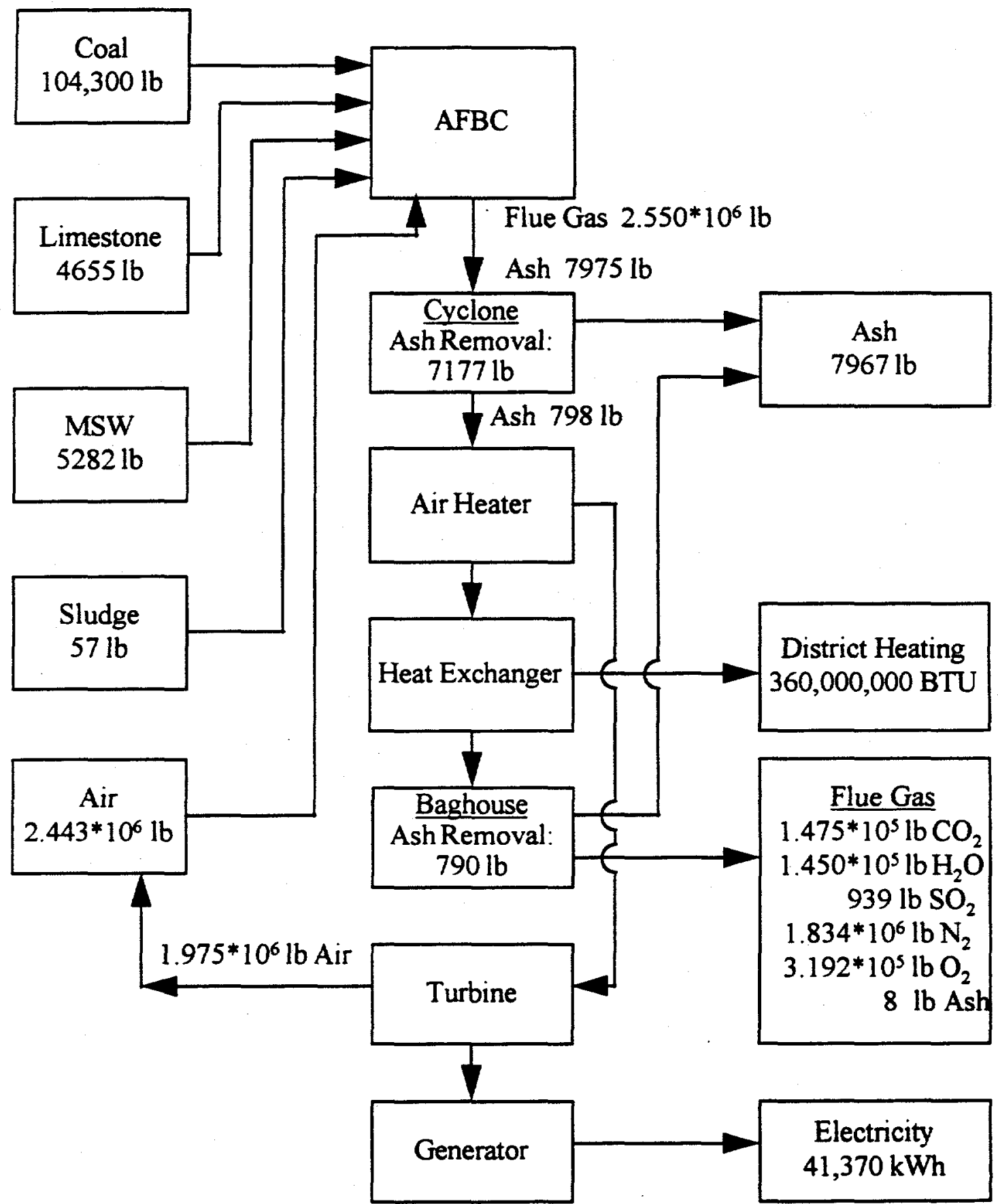


Figure 17: Quantitative Flow Diagram for Wastewater Treatment

Basis: One operating day

Unit designed to treat 60,000 gallons per day of wastewater and sewage

$\underline{\text { Raw Materials }}$

Processing

Products

\begin{tabular}{|cc|}
\hline Wastewater \\
$60,000 \mathrm{gal}$ \\
$\mathrm{BOD}_{\mathrm{s}} 210 \mathrm{ppm}$ \\
$\mathrm{COD}$ & $350 \mathrm{ppm}$ \\
$\mathrm{N}$ & $20 \mathrm{mg} / \mathrm{L}$ \\
$\mathrm{P}$ & $4 \mathrm{mg} / \mathrm{L}$ \\
\hline
\end{tabular}

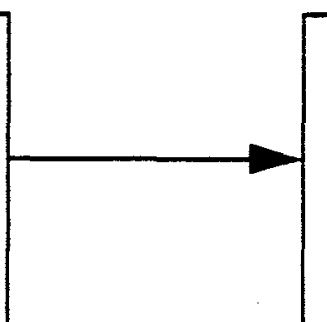

Bar Screen
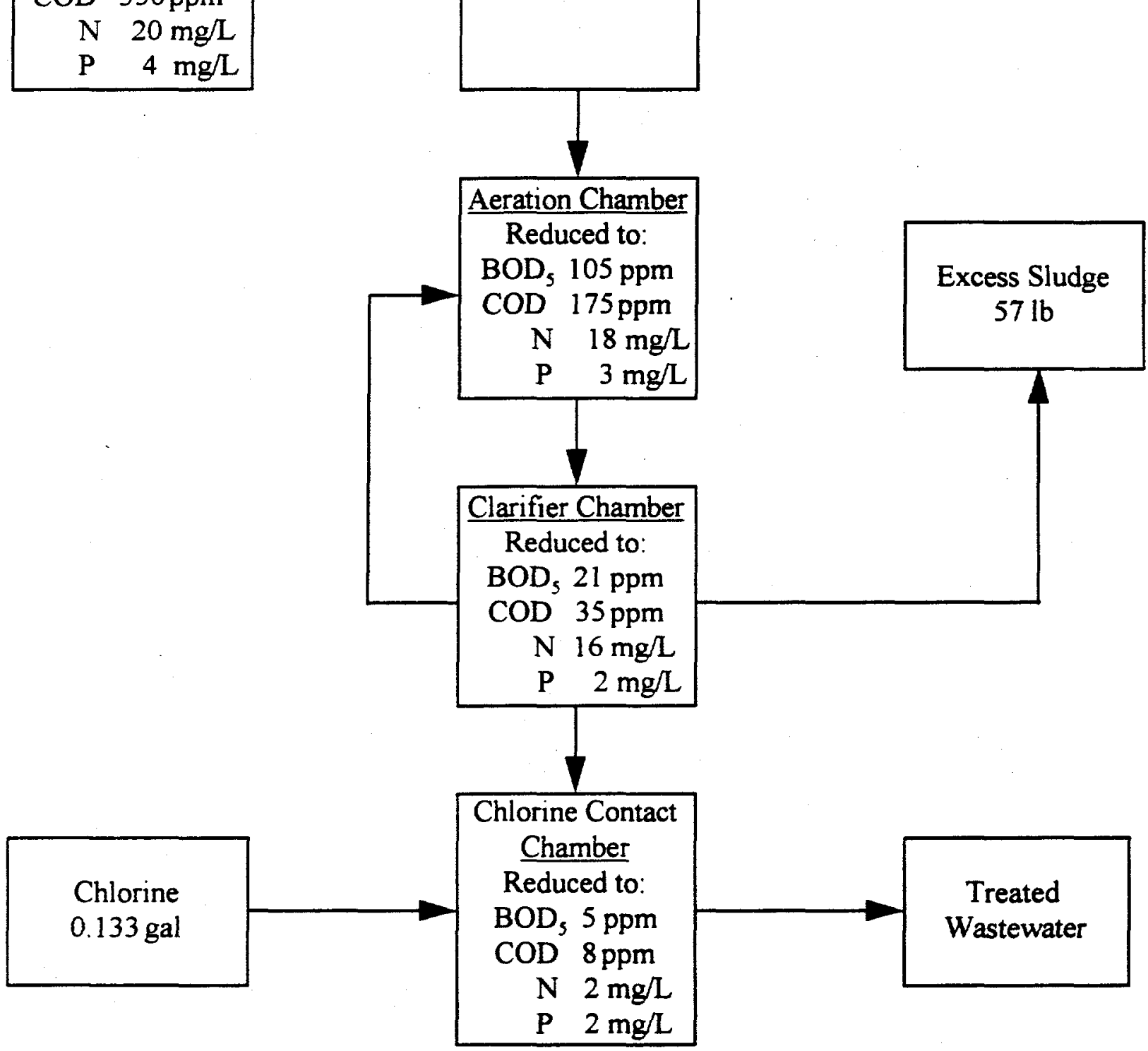
APPENDIX C: Area 100: Storage and Handling 


\section{Area 100: Storage and Handling}

\section{Raw Materials Storage}

The fuel used to generate power and heating consists of coal, municipal solid waste (MSW), wood, and sludge. In addition, limestone will be added to reduce sulfur dioxide emissions. The raw materials will be stored next to the size reduction building in separate facilities. However, the MSW and wood will be stored together in the size reduction building.

A one month's supply of coal will be stockpiled (F100) outside in an area 100 feet in length and 50 feet in width. The coal will be received by truck from the Jarvis Creek Mine approximately 136 miles west of Tok.

The limestone will be received in large bags on four foot pallets. A one month's supply will be stored in an indoor facility (F110) 12 feet long, 12 feet wide, and 12 feet high. It is critical that the limestone remain dry.

The MSW and wood will be received once a week by truck. It will be dumped into an unheated building that will protect it from the wind, rain, and snow. The storage building (F120) will be 16 feet in both length and width, and 15 feet high.

\section{Size Reduction}

Before the raw materials can be sent to the atmospheric fluidized bed combustor (AFBC), they need to be reduced to a suitable size for transportation and fluidization. All raw materials are transported to their reduction equipment using payloaders. The coal will be reduced to a minus one-half inch size by a jaw crusher ( $\mathrm{C} 130)$ having a capacity of 86 tons per hour (ton $/ \mathrm{hr}$ ). It will operate at 60 horsepower (hp). The limestone will be sent through a $25 \mathrm{hp} \mathrm{jaw}$ crusher (C140) having a capacity of $20 \mathrm{ton} / \mathrm{hr}$. The MSW and wood will first be shredded and then cubed to a one-inch size. Cubing is necessary so that the shredded MSW and wood will not blow out of the AFBC with the flue gas. The shredder and cuber system (C150) will operate at $10 \mathrm{hp}$ and will have a capacity of $2000 \mathrm{lb} / \mathrm{hr}$. 


\section{Transportation of Raw Materials}

After being reduced to the appropriate sizes, the raw materials are then transported to separate hoppers in the main building by belt conveyors each 100 feet in length. The coal conveyor (J135) is two feet wide and feeds into the coal hopper (F160) having a capacity of one day's storage. The coal hopper is 13 feet long, 13 feet wide, and 12 feet high. Both the limestone and MSW conveyors (J145 and J155, respectively) are two feet in width. The limestone conveyor sends the limestone to a hopper (F170) having the dimension of five feet for length, width, and height. This will hold two day's supply of limestone. The cubed MSW and wood are conveyed to another hopper (F180) that has a length and width of 10 feet and a height of 11 feet.

A screw conveyor will transport the raw materials from each of the hoppers into a mixed feed hopper (F190) that can hold one day's supply of each raw material. Another screw conveyor will transport the fuel from the feed hopper into the bottom of the AFBC (R200). The feed hopper will have a width and length of 14 feet and a height of 13 feet. All four screw conveyors will have capacities of three ton/hr, diameters of one and onehalf feet, and rotate between 0 and 15.9 revolutions per minute (rpm). The lengths of each will differ, however. The coal, limestone, MSW, and mixed feed conveyors (J165, $\mathrm{J} 175$, J185, and J195) will have lengths of 12 feet, 5 feet, 12 feet, and 20 feet, respectively.

Table 10: Area 100: Storage and Handling Equipment

\begin{tabular}{|c|c|c|c|c|}
\hline Item No. & Description & Dimensions & Material & Cost \\
\hline & Payloader & 18 feet $^{3}$ capacity & & $\$ 20,000$ \\
\hline & Fork lift & $3000 \mathrm{lb}$ capacity & & \$ 25,000 \\
\hline $\mathrm{Cl30}$ & Coal jaw crusher & $\begin{array}{l}\text { Capacity }=86 \text { ton } / \mathrm{hr} \\
\text { Power }=60 \mathrm{hp}\end{array}$ & Carbon steel & $\$ 74,000$ \\
\hline 3135 & $\begin{array}{l}\text { Belt conveyor from coal } \\
\text { crusher to coal hopper }\end{array}$ & $\begin{array}{l}\text { Width }=3 \text { feet } \\
\text { Length }=100 \text { feet }\end{array}$ & Rubber belt & $\$ 63,000$ \\
\hline $\mathrm{Cl40}$ & Limestone jaw crusher & $\begin{array}{l}\text { Capacity }=20 \text { ton } / \mathrm{hr} \\
\text { Power }=25 \mathrm{hp}\end{array}$ & Carbon steel & $\$ 18,000$ \\
\hline $\mathrm{J145}$ & $\begin{array}{l}\text { Belt conveyor from limestone } \\
\text { crusher to limestone hopper }\end{array}$ & $\begin{array}{l}\text { Width }=2 \text { feet } \\
\text { Length }=100 \text { feet }\end{array}$ & Rubber belt & $\$ 48,000$ \\
\hline
\end{tabular}




\begin{tabular}{|c|c|c|c|c|}
\hline Item No. & Description & Dimensions & Material & Cost \\
\hline \multirow[t]{2}{*}{ C150 } & \multirow[t]{2}{*}{$\begin{array}{l}\text { MSW and wood shredder } \\
\text { and Cuber }\end{array}$} & $\begin{array}{l}\text { Shredder } \\
\text { Capacity }=2000 \mathrm{lb} / \mathrm{hr} \\
\text { Power }=10 \mathrm{hp}\end{array}$ & Carbon steel & $\$ 41.000$ \\
\hline & & $\begin{array}{l}\text { Cuber } \\
\text { Capacity }=2000 \mathrm{lb} / \mathrm{hr} \\
\text { Cube size }=1 \mathrm{inch}\end{array}$ & Carbon steel & $\$ 89.000$ \\
\hline $\mathrm{J155}$ & $\begin{array}{l}\text { Conveyor from cuber to } \\
\text { MSW and wood hopper }\end{array}$ & $\begin{array}{l}\text { Width }=2 \text { feet } \\
\text { Length }=100 \text { feet }\end{array}$ & Rubber belt & $\$ 48,000$ \\
\hline$F 160$ & $\begin{array}{l}\text { Coal hopper to store one } \\
\text { day's supply of crushed } \\
\text { coal }\end{array}$ & $\begin{array}{l}\text { Height = } 12 \text { feet } \\
\text { Width = } 13 \text { feet } \\
\text { Length = } 13 \text { feet }\end{array}$ & Carbon steel & $\$ 8,000$ \\
\hline $\mathrm{J165}$ & $\begin{array}{l}\text { Screw conveyor from coal } \\
\text { hopper to feed hopper }\end{array}$ & $\begin{array}{l}\text { Capacity }=3 \text { ton } / \mathrm{hr} \\
\text { Diameter }=1.5 \text { feet } \\
0-15.9 \mathrm{rpm} \\
\text { Length }=12 \text { feet }\end{array}$ & Plate steel & $\$ 9,000$ \\
\hline $\mathrm{F} 170$ & $\begin{array}{l}\text { Limestone hopper to store } \\
\text { two day's supply of crushed } \\
\text { limestone }\end{array}$ & $\begin{array}{l}\text { Height }=5 \text { feet } \\
\text { Width = } 5 \text { feet } \\
\text { Length }=5 \text { feet }\end{array}$ & Carbon steel & $\$ 500$ \\
\hline 3175 & $\begin{array}{l}\text { Screw conveyor from } \\
\text { limestone hopper to } \\
\text { feed hopper }\end{array}$ & $\begin{array}{l}\text { Capacity }=3 \text { ton } / \mathrm{hr} \\
\text { Diameter }=1.5 \text { feet } \\
0-15.9 \mathrm{rpm} \\
\text { Length }=5 \text { feet }\end{array}$ & Carbon steel & $\$ 5,000$ \\
\hline F180. & $\begin{array}{l}\text { MSW and wood hopper to } \\
\text { store two day's supply of } \\
\text { MSW and wood }\end{array}$ & $\begin{array}{l}\text { Height }=11 \text { feet } \\
\text { Width }=10 \text { feet } \\
\text { Length }=10 \text { feet }\end{array}$ & Carbon steel & $\$ 4,000$ \\
\hline $\mathrm{J} 185$ & $\begin{array}{l}\text { Screw conveyor from MSW } \\
\text { and wood hopper to feed } \\
\text { hopper }\end{array}$ & $\begin{array}{l}\text { Capacity }=3 \text { ton } / \mathrm{hr} \\
\text { Diameter }=1.5 \text { feet } \\
0-15.9 \mathrm{rpm} \\
\text { Length }=12 \text { feet }\end{array}$ & Plate steel & $\$ 9,000$ \\
\hline F190 & $\begin{array}{l}\text { Feed hopper to store one } \\
\text { day's supply of fuel and } \\
\text { limestone }\end{array}$ & $\begin{array}{l}\text { Height }=13 \text { feet } \\
\text { Width }=14 \text { feet } \\
\text { Length }=14 \text { feet }\end{array}$ & Carbon steel & \$ $\quad 10,000$ \\
\hline$J 195$ & $\begin{array}{l}\text { Screw conveyor from feed } \\
\text { hopper to AFBC }\end{array}$ & $\begin{array}{l}\text { Capacity }=3 \text { ton } / \mathrm{hr} \\
\text { Diameter }=1.5 \text { feet } \\
\text { Length }=20 \text { feet } \\
0-15.9 \mathrm{rmm}\end{array}$ & Plate steel & $\$ 12,000$ \\
\hline F199 & $\begin{array}{l}\text { Wastew ater sludge bin for } \\
\text { three day's capacity }\end{array}$ & $\begin{array}{l}\text { Height }=4 \text { feet } \\
\text { Diameter }=4 \text { feet }\end{array}$ & Carbon steel & \$ 3,000 \\
\hline Total & & & & $\$ 486,500$ \\
\hline
\end{tabular}


APPENDIX D: Area 200: Fuel Combustion 


\section{Area 200: Fuel Combustion}

\section{Atmospheric Fluidized Bed Combustor (R200)}

The AFBC (R200) was designed to operate at $1550^{\circ} \mathrm{F}$, to minimize the formation of nitrogen oxides. The AFBC will be constructed of carbon steel that is lined with eight inches of insulating refractory. The boiler efficiency and fluidization velocity were assumed to be 80 percent and eight feet per second, respectively. A square bed will be used instead of a circular bed to provide a better fuel distribution. ${ }^{5}$ The AFBC is 17 feet tall and will have a cross-sectional area of 196 square feet.

\section{Fan (G210)}

In addition to the fuel, approximately $2,443,000 \mathrm{lbs} /$ day of air will be required to operate the AFBC. The air will come from two sources: a centrifugal fan (G210) and a gas turbine (N310). The centrifugal fan is a backward inclined blade fan which was chosen because it is efficient and reduces erosion from light dust in the air. It will supply 468,000 $\mathrm{lbs} /$ day of the required air. A $20 \mathrm{SISW}$ (single inlet, single width) fan operating at 1330 rotations per minute (RPM) with a two horsepower (hp) motor is required. The hot air gas turbine, which is described in the Area 300 section, will supply the remaining $1,975,000 \mathrm{lbs} /$ day.

\section{Cyclone (H220)}

Flue gas leaves the AFBC at a rate of $2,550,000 \mathrm{lbs} /$ day and a temperature of $1550^{\circ} \mathrm{F}$. Immediately after leaving the AFBC the flue gas passes through a cyclone (H220) constructed of carbon steel, where 91 percent of its ash is removed. Four inches of insulating refractory will line the cyclone to keep the metal temperature low. ${ }^{5}$ The cyclone will have a diameter of 1.5 feet and be 3.2 feet tall.

The ash removed by the cyclone will fall into an ash bin (F230) with length, width, and height of seven feet constructed of mild steel. The bin will have a two day holding capacity. 
Table 11: Area 200: Fuel Combustion Equipment

\begin{tabular}{|c|c|c|c|c|}
\hline Item No. & Description & Dimensions & Material & Cost \\
\hline $\mathrm{R} 200$ & $\begin{array}{l}\text { Atmospheric Fluidized Bed } \\
\text { Combustor }\end{array}$ & $\begin{array}{l}\text { Height }=17 \text { feet } \\
\text { Width }=14 \text { feet } \\
\text { Length }=14 \text { feet }\end{array}$ & $\begin{array}{l}\text { Carbon steel } \\
\text { with } 8 \text { inches } \\
\text { of insulating } \\
\text { refractory }\end{array}$ & $\$ 545,000$ \\
\hline $\mathrm{G} 210$ & $\begin{array}{l}\text { Centrifugal fan to supply } \\
\text { atmospheric air to AFBC }\end{array}$ & $\begin{array}{l}468,000 \mathrm{lb} / \text { day air } \\
\text { Power }=2 \mathrm{hp}\end{array}$ & Carbon steel & 2,000 \\
\hline $\mathrm{H} 22 \mathrm{O}$ & $\begin{array}{l}\text { Cyclone to remove flyash } \\
\text { from the fluegas }\end{array}$ & $\begin{array}{l}\text { Diameter }=1.56 \text { feet } \\
\text { Height }=3.2 \text { feet }\end{array}$ & $\begin{array}{l}\text { Carbon steel } \\
\text { with } 4 \text { inches } \\
\text { of insulating } \\
\text { refractory }\end{array}$ & $\begin{array}{ll}\$ & 30,000\end{array}$ \\
\hline F230 & $\begin{array}{l}\text { Storage bin for flyash from } \\
\text { cyclone ( } 2 \text { day capacity) }\end{array}$ & $\begin{array}{l}\text { Height }=7 \text { feet } \\
\text { Width }=7 \text { feet } \\
\text { Length }=7 \text { feet }\end{array}$ & Carbon steel & 1,000 \\
\hline Total & & & & $\$ 578,000$ \\
\hline
\end{tabular}


APPENDIX E: Area 300: Power Generation 


\section{Area 300: Power Generation}

\section{Air Heater (E300)}

Hot flue gas from the cyclone $(\mathrm{H} 220)$ enters the shellside of a 1-2 parallel-counterflow shell and tube air heater (E300) made of 316 stainless steel. Air from the gas turbine compressor $(\mathrm{N} 310)$ travels through the tubeside of the air heater where it is heated from $328^{\circ} \mathrm{F}$ to $1440^{\circ} \mathrm{F}$. The required heat transfer area is 674 square feet $\left(\mathrm{f}^{2}\right)$.

\section{Turbine (N310) and Generator (P320)}

The pressurized hot air leaving the air heater at $1440^{\circ} \mathrm{F}$ and four atmospheres is reduced to $1280^{\circ} \mathrm{F}$ and one atmosphere by expansion through the turbine. The mechanical work done by the hot gas expansion supplies the power required by the generator to generate 41,370 kilowatt-hours per day ( $\mathrm{kWh} /$ day) of electricity. ${ }^{3}$ The net work generated by the turbine is 141 million BTU per day assuming a 90 percent mechanical efficiency for the compressor and turbine.

Table 12: Area 300: Power Generation Equipment

\begin{tabular}{|l|l|l|l|c|}
\hline Item No. & Description & Dimensions & Material & Cost \\
\hline E300 & $\begin{array}{l}\text { Air heater to heat air from } \\
\text { turbine compressor }\end{array}$ & $\begin{array}{l}\text { Heat transfer area } \\
674 \text { feet }^{2}\end{array}$ & Stainless steel & $\$ 31,000$ \\
\hline N310 & Hot Air Gas Turbine & $1,975,000 \mathrm{lb} /$ day air & Carbon steel & $\$ 867,000$ \\
\hline P320 & $\begin{array}{l}\text { Generator to convert mechanical } \\
\text { work to } \\
\text { electricity }\end{array}$ & $41,370 \mathrm{kWh} /$ day & Carbon steel & \\
\hline Total & & & & $\$ 898,000$ \\
\hline
\end{tabular}




\section{APPENDIX F: Area 400: District Heating}




\section{Area 400: District Heating}

\section{Heat Exchanger (E400)}

Hot flue gas from the air heater enters the shellside of a 1-2 parallel-counterflow, shell and tube, water/glycol heat exchanger (E400) made of carbon steel. The water/glycol stream returning from the district, at 20.7 million lbs/day, enters the tubeside at $180^{\circ} \mathrm{F}$ and exits at $200^{\circ} \mathrm{F}$. This provides the community of Tok with 360 million BTU/day of heat. ${ }^{2}$ The required heat transfer area is 500 square feet $\left(\mathrm{ft}^{2}\right)$.

\section{Pump (L410)}

The pump size required to circulate the water/glycol mixture for district heating was calculated using an estimate of 25,000 feet of pipe and 150 feet of total dynamic head. ${ }^{2}$ The flow rate of the mixture is 1776 gallons per minute and will require a $109 \mathrm{hp}$ pump.

Table 13: Area 400: District Heating Equipment

\begin{tabular}{|l|l|l|l|c|}
\hline Item No. & Description & Dimensions & Material & Cost \\
\hline E400 & $\begin{array}{l}\text { Heat exchanger for district } \\
\text { heating (water glycol stream) }\end{array}$ & $\begin{array}{l}\text { Heat transfer area } \\
500 \text { feet }^{2}\end{array}$ & Carbon steel & $\$ 13,000$ \\
\hline L410 & $\begin{array}{l}\text { Pump to circulate water/glycol } \\
\text { stream through Tok }\end{array}$ & $\begin{array}{l}1776 \mathrm{gal} / \mathrm{min} \\
\text { Power }=109 \mathrm{hp}\end{array}$ & Carbon steel & $\$ \mathbf{8 , 0 0 0}$ \\
\hline Total & & & & $\$ 21,000$ \\
\hline
\end{tabular}


APPENDIX G: Area 500: Particulate Removal 


\section{Area 500: Particulate Removal}

\section{Baghouse (H500)}

The flue gas from the water/glycol heat exchanger will enter the baghouse (H500), where the fly ash removal will be completed. The baghouse will be constructed of three compartments each containing 398 bags. The bags will be constructed of a Dacron material to withstand the temperature of the flue gas. Each bag will contain $12.5 \mathrm{ft}^{2}$ of material. The baghouse has an efficiency of 99 percent. Therefore, the exiting flue gas will enter the atmosphere with seven pounds of ash per day. The national standard for ash emissions is 29 pounds per day.

The baghouse may be cleaned without shutdown time. The baghouse can operate with two compartments while the third is cleaned.

The fly ash removed by the baghouse will be collected in a bin (F510) four feet high and three feet in both length and width. The bin will have a two day holding capacity. Fly ash will be sold if possible, otherwise it will be disposed of in a landfill.

Table 14: Area 500: Particulate Removal Equipment

\begin{tabular}{|l|l|l|l|r|}
\hline Item No. & Description & Dimensions & Material & Cost \\
\hline H500 & $\begin{array}{l}\text { Baghouse to remove final } \\
\text { flyash from flue gas }\end{array}$ & $\begin{array}{l}\text { Compartments }=3 \\
\text { Bags/Compartment =398 }\end{array}$ & $\begin{array}{l}\text { Carbon steel } \\
\text { shell Dacron } \\
\text { bags }\end{array}$ & $\$ 544,000$ \\
\hline F510 & $\begin{array}{l}\text { Storage bin for flyash from } \\
\text { baghouse (2 day capacity) }\end{array}$ & $\begin{array}{l}\text { Height =4 feet } \\
\text { Width = feet } \\
\text { Length = 3 feet }\end{array}$ & Carbon steel & $\$ 150$ \\
\hline Total & & & & $\$ 544,150$ \\
\hline
\end{tabular}


APPENDIX H: Area 600: Wastewater Treatment 


\section{Area 600: Wastewater Treatment System}

The wastewater treatment system will be purchased as a package system from Tipton Environmental International Inc. (TEII), located in Milford, Ohio. The system will include all tank vessels, components, and equipment necessary for efficient and proper plant operation. A field contractor from TEII will perform the actual installation of the system. The system will be capable of handling a fluctuation in the average daily flow rate of 50 percent to 100 percent with the peak flow rate not to exceed 250 percent of the rated capacity.

\section{Construction Material}

One-fourth inch structural grade steel plating will be used for construction of all vessels. The piping in the system will be six inch painted steel pipes. All vessels and pipes will be constructed of a painted steel to prevent corrosion. The painting process will start with the steel being prepared by wire brushing and cleaning. They will then be painted with "Koppers" coal tar bitumastic \#50 to a total dry film thickness of 8-10 Mils. ${ }^{19}$

\section{Pump (L600)}

Wastewater from Tok will be pumped to the treatment plant at 60,000 gallons per day (gal/d). Based on 70 feet of head and a pump efficiency of 60 percent, a one horsepower pump will be required.

\section{Bar Screen $(\mathrm{H} 610)^{19}$}

The wastewater will pass through a bar screen $(\mathrm{H} 610)$ to remove all large solids before entering the aeration chamber. The bar screen will be constructed from one-half inch diameter bars spaced one inch apart. The bar screen will be sloped for easy cleaning. Removed solids will drop onto a drying deck.

The bar screen serves as a safety device for the system. If larger solids enter the system it could cause the system to become clogged. This would result in more down time for maintenance. 


\section{Aeration Chamber (R620) ${ }^{19}$}

The wastewater will enter the aeration chamber (R620) once it passes through the bar screen. The aeration chamber will reduce the biochemical oxygen demand $\left(\mathrm{BOD}_{5}\right)$ and chemical oxygen demand (COD) along with maintaining a dissolved oxygen level of two $\mathrm{mg} / \mathrm{L}$. Retention time in the chamber will be 24 hours. The chamber will have a volume of 72,000 gallons. The sides of the chamber will be shaped so the sludge will not accumulate along the sides. The dimensions of depth to width will not exceed 1.33:1.

An air diffuser placed along one side of the chamber will be used in conjunction with flow control baffles to give optimum mixing and retention time. Each diffuser will be equipped with an air regulatory and shutoff valve and a diffuser bar with non-clog air diffuser nozzles. The diffusers will be an air check diaphragm with twenty $3 / 16$ inch diameter air discharge holes evenly distributed on the diffuser body. The air flow per diffuser shall range from one to five cubic feet per minute (cfm).

\section{Clarifier Chamber (R630) $)^{19}$}

Once the activated sludge and oxygen in the aeration table reduces the COD and BOD, the wastewater enters the clarifier chamber (R630). Here the solids will settle out of the water and either be pumped back into the aeration chamber (R620) or pumped to the sludge bin (F199). The clarifier chamber will have a volume of 11,000 gallons and a retention time of four hours. The effluent will pass over a baffled adjustable effluent weir into a trough and out of the chamber.

\section{Sludge Recirculation System ${ }^{19}$}

This system will recycle the activated sludge to either the aeration chamber or to the sludge bin. Two four inch diameter air lift sludge return assemblies will be used. The airlift pump system will have the capacity to recycle zero percent to 150 percent of the design flow. A needle valve will be used to vary the capacity of the pump. A clean-out plug will allow for easy cleaning and maintenance. 


\section{Sludge Disposal}

Sludge that is not recycled back into the aeration chamber will enter a sludge bin (F199), which has a height and diameter of four feet. The sludge will be pumped to the AFBC (R200) to be burned. A $0.01 \mathrm{hp}$ positive displacement pump will be used to pump the 88 gallons per day of sludge.

\section{Chlorine Contact Chamber (R650)}

The water leaving the clarifier chamber then enters the chlorine contact chamber (R650) The chamber will be 1250 gallons and provide a 30 minute retention time. A hypo chlorination system will be used. This consists of a solution crock that will contain the

- clorox solution (five percent chlorine). The solution crock will be refilled approximately every 15 days with two gallons of clorox. The treated water will flow from the chlorine chamber into the Tanana River.

Table 15: Area 600: Wastewater Treatment Equipment*

\begin{tabular}{|c|c|c|c|}
\hline Item No. & Description & Dimensions & Cost \\
\hline L600 & Pump the water from Tok to plant & $\begin{array}{l}60,000 \text { gal } / \text { day } \\
\text { Power }=1 \mathrm{hp}\end{array}$ & $\$ 2,000$ \\
\hline $\mathrm{H} 610$ & Bar screen to remove large solids & $\begin{array}{l}\text { Bar Spacing }=1 \text { inch } \\
\text { Bar Diameter }=1 / 2 \text { inch }\end{array}$ & \multirow[t]{6}{*}{$\$ 75,000$} \\
\hline R620 & $\begin{array}{l}\text { Aeration chamber which controls } \\
\text { oxygen level and reduces } \mathrm{BOD}_{5} \mathrm{~s} \\
\text { and CODs }\end{array}$ & $\begin{array}{l}\text { Volume }=72,000 \text { gallons } \\
\text { Depth:Width }=1.33: 1 \\
\text { Retention Time }=24 \text { hours }\end{array}$ & \\
\hline R630 & Clarifier chamber to remove solids & $\begin{array}{l}\text { Volume }=11,000 \text { gallons } \\
\text { Retention Time }=4 \text { hours }\end{array}$ & \\
\hline L640 & $\begin{array}{l}\text { Pump to recirculate activated sludge } \\
\text { from clarifier to aeration chamber }\end{array}$ & 4 inch airlift sludge pump & \\
\hline R650 & $\begin{array}{l}\text { Chlorine contact chamber to kill } \\
\text { bacteria }\end{array}$ & $\begin{array}{l}\text { Volume }=1250 \text { gallons } \\
\text { Retention Time }=30 \mathrm{~min} .\end{array}$ & \\
\hline F660 & $\begin{array}{l}\text { Wastewater storage tank to hold up } \\
\text { to one day's supply of wastewater }\end{array}$ & 72,000 gallon capacity & \\
\hline L670 & Pump the sludge to AFBC & $\begin{array}{l}88 \mathrm{gal} / \text { day } \\
\text { Power }=0.01 \mathrm{hp}\end{array}$ & 300 \\
\hline Total & & & $\$ 77,300$ \\
\hline
\end{tabular}

- All pieces of equipment are constructed of a painted steel 
APPENDIX I: Stream Summaries 
Table 16: Power Generation Streams

\begin{tabular}{|c|c|c|c|c|c|c|c|c|c|c|}
\hline & $\mathbf{S 1}$ & S2 & 53 & S $4 A, B, C$ & S5A,B,C,D & $56 A, B, C$ & $\mathbf{5 7}$ & $\mathbf{S 8}$ & $\mathbf{5 9}$ & $\mathbf{5 1 0}$ \\
\hline Air (Ib/day) & 468,000 & & & & $1.98 \times 10^{6}$ & & & & & \\
\hline Ash (lb/day) & & 7,980 & 7,180 & 798 & & & 8 & 790 & 790 & \\
\hline Carbon Dioxide (Ib/day) & & $1.48 \times 10^{5}$ & & $1.48 \times 10^{5}$ & & & $1.48 \times 10^{5}$ & & & \\
\hline Electricity (kWh/day) & & & & & & & & & & $4.14 \times 10^{4}$ \\
\hline Heat (BTU/day) & & & & & & $3.60 \times 10^{8}$ & & & & \\
\hline Nitrogen (lb/day) & & $1.83 \times 10^{6}$ & & $1.83 \times 10^{6}$ & & & $1.83 \times 10^{6}$ & & & \\
\hline Oxygen (Ib/day) & & $3.19 \times 10^{5}$ & & $3.19 \times 10^{5}$ & & & $3.19 \times 10^{5}$ & & & \\
\hline Sulfur Dioxide (Ib/day) & & 939 & & 939 & & & 939 & & & \\
\hline Water (Ib/day) & & $1.45 \times 10^{5}$ & & $1.45 \times 10^{5}$ & & & $1.45 \times 10^{5}$ & & & \\
\hline Total & 468,000 & $2.44 \times 10^{6}$ & 7,180 & $2.44 \times 10^{6}$ & $1.98 \times 10^{6}$ & $3.60 \times 10^{8}$ & $2.40 \mathrm{~s} 10^{6}$ & 790 & 790 & $4.14 \times 10^{4}$ \\
\hline
\end{tabular}

Table 17: Wastewater Treatment Streams

\begin{tabular}{|l|c|c|c|c|c|c|c|c|}
\hline & S11A,B,C & S12 & S13 & S14A,B & S15 & S16A,B,C & S17 & S18 \\
\hline BOD (ppm) & 210 & 105 & 21 & & & & 5 \\
\hline COD (ppm) & 350 & 175 & 35 & & & & & \\
\hline $\begin{array}{c}\text { Clorox (5\% Chlorine) } \\
\text { (gal/day) }\end{array}$ & & & & & & & 0.133 & 0.133 \\
\hline $\begin{array}{l}\text { Nitrogen (mg/L) } \\
\text { Phosphorus (mg/L) }\end{array}$ & 20 & 18 & 16 & & & & 2 \\
\hline Water (gal/day) & $6.00 \times 10^{4}$ & $6.00 \times 10^{4}$ & $6.00 \times 10^{4}$ & 44 & 22 & 22 & & 2 \\
\hline Solids (dry Ib/day) & 57 & 57 & & 57 & 28 & 29 & & $6.00 \times 10^{4}$ \\
\hline
\end{tabular}


APPENDIX J: Cash Flow Table 
Table 18: Cash Flows

\begin{tabular}{|c|c|c|c|c|c|c|c|c|c|c|}
\hline Year & & $\begin{array}{l}\text { Annual } \\
\text { venue (R) }\end{array}$ & $\begin{array}{c}\text { Annual } \\
\text { Costs (C) }\end{array}$ & $\begin{array}{l}\text { BTCF } \\
\text { R-C }\end{array}$ & $\begin{array}{c}\text { MACRS } \\
\text { Depreciation }\end{array}$ & $\begin{array}{c}\text { Taxable } \\
\text { Income (TI) }\end{array}$ & $\begin{array}{c}\text { Cummulative } \\
\mathrm{TI}\end{array}$ & $\begin{array}{c}\text { Annual Taxes } \\
\text { f(TI) }\end{array}$ & $\begin{array}{c}\text { ATCF } \\
\text { BTCF-f(T) }\end{array}$ & $\begin{array}{c}\text { ATCF } \\
\text { Cummulative }\end{array}$ \\
\hline 0 & $\$$ & - & $\$ 18,066,000$ & $\$(18,065,689)$ & & & & & $\$(18,066,000)$ & $\$(18,066,000)$ \\
\hline 1 & $\$$ & $4,412,000$ & $\$ 4,109,000$ & 304,000 & 824,000 & $(520,000)$ & & $\$$ & 304,000 & $\$(17,762,000)$ \\
\hline 2 & $\$$ & $4,412,000$ & $\$ 4,109,000$ & 304,000 & $\$ 1,478,000$ & $\$(1,174,000)$ & & $\$$ & 304,000 & $\$(17,458,000)$ \\
\hline 3 & $\$$ & $4,412,000$ & $\$ 4,109,000$ & 304,000 & $\$ 1,240,000$ & $\$ \quad(936,000)$ & & $\$$ & 304,000 & $\$(17,155,000)$ \\
\hline 4 & $\$$ & $4,412,000$ & $\$ 4,109,000$ & 304,000 & $\$ 1,056,000$ & $\$(753,000)$ & & $\$$ & 304,000 & $\$(16,851,000)$ \\
\hline 5 & 5 & $4,412,000$ & $\$ 4,109,000$ & 304,000 & 913,000 & $(610,000)$ & & $\$$ & 304,000 & $\$(16,547,000)$ \\
\hline 6 & $\$$ & $4,412,000$ & $\$ 4,109,000$ & 304,000 & 864,000 & $(560,000)$ & & $\$$ & 304,000 & $\$(16,244,000)$ \\
\hline 7 & $\$$ & $4,412,000$ & $\$ 4,109,000$ & 304,000 & 819,000 & $(516,000)$ & & $\$$ & 304,000 & $\$(15,940,000)$ \\
\hline 8 & $\$$ & $4,412,000$ & $\$ 4,109,000$ & 304,000 & 665,000 & $(362,000)$ & & $\$$ & 304,000 & $\$(15,636,000)$ \\
\hline 9 & $\$$ & $4,412,000$ & $\$ 4,109,000$ & 304,000 & 546,000 & $(243,000)$ & & $\$$ & 304,000 & $\$(15,333,000)$ \\
\hline 10 & $\$$ & $4,412,000$ & $\$ 4,109,000$ & 304,000 & 546,000 & $(243,000)$ & & $\$$ & 304,000 & $\$(15,029,000)$ \\
\hline 11 & $\$$ & $4,412,000$ & $\$ 4,109,000$ & 304,000 & 546,000 & $(242,000)$ & & $\$$ & 304,000 & $\$(14,725,000)$ \\
\hline 12 & $\$$ & $4,412,000$ & $\$ 4,109,000$ & 304,000 & 545,000 & $(242,000)$ & & $\$$ & 304,000 & $\$(14,422,000)$ \\
\hline 13 & 5 & $4,412,000$ & $\$ 4,109,000$ & 304,000 & 546,000 & $(242,000)$ & & $\$$ & 304,000 & $\$(14,118,000)$ \\
\hline 14 & $\$$ & $4,412,000$ & $\$ 4,109,000$ & 304,000 & 545,000 & $(242,000)$ & & $\$$ & 304,000 & $\$(13,814,000)$ \\
\hline 15 & $\$$ & $4,412,000$ & $\$ 4,109,000$ & 304,000 & 546,000 & $(242,000)$ & $(242,000)$ & $\$$ & 304,000 & $\$(13,511,000)$ \\
\hline 16 & $\$$ & $4,412,000$ & $\$ 4,109,000$ & 304,000 & 543,000 & $(240,000)$ & $(481,000)$ & $\$$ & 304,000 & $\$(13,207,000)$ \\
\hline 17 & $\$$ & $4,412,000$ & $\begin{array}{ll}\$, 109,000 \\
\end{array}$ & 304,000 & 541,000 & $(237,000)$ & $(719,000)$ & $\$$ & 304,000 & $\$(12,903,000)$ \\
\hline 18 & 5 & $4,412,000$ & $\$ 4,109,000$ & 304,000 & 541,000 & $(237,000)$ & $(956,000)$ & $\$$ & 304,000 & $\$(12,600,000)$ \\
\hline 19 & $\$$ & $4,412,000$ & $\$ 4,109,000$ & 304,000 & 541,000 & $(237,000)$ & $\$(1,194,000)$ & $\$$ & 304,000 & $\$(12,296,000)$ \\
\hline 20 & $\bar{s}$ & $7,418,000$ & $\begin{array}{ll}\$, 109,000 \\
\end{array}$ & 304,000 & 541,000 & \begin{tabular}{|l|}
$\$ 2,769,000$ \\
\end{tabular} & $\$ 1,575,000$ & 536,000 & \begin{tabular}{|ll}
$\$$ & $2,774,000$ \\
\end{tabular} & \$ $(9,522,000)$ \\
\hline
\end{tabular}


APPENDIX K: Process Flow Calculations 
Determining Heat Capacity of Flue Gas ${ }^{16}$ :

Temperature Dependence on Heat Capacity:

$$
C_{p} i g / R=A+B T+C T^{2}+D T^{-2}
$$

Temperature must be in Kelvin (K)

$$
\begin{aligned}
& \mathrm{CO}_{2} \quad \mathrm{C}_{\mathrm{A}}=5.457 \quad \mathrm{C}_{\mathrm{B}}:=1.045 \cdot 10^{-3} \quad \mathrm{C}_{\mathrm{D}}=-1.157 \cdot 10^{5} \quad \mathrm{y}_{\mathrm{C}}=0.0603 \\
& \mathrm{H}_{2} \mathrm{O} \quad \mathrm{H}_{\mathrm{A}}=3.470 \quad \mathrm{H}_{\mathrm{B}}=1.450 \cdot 10^{-3} \quad \mathrm{H}_{\mathrm{D}}=0.121 \cdot 10^{5} \quad \mathrm{y}_{\mathrm{H}}=0.0593 \\
& \mathrm{SO}_{2} \quad \mathrm{~S}_{\mathrm{A}}=5.699 \quad \mathrm{~s}_{\mathrm{B}}=0.801 \cdot 10^{-3} \quad \mathrm{~S}_{\mathrm{D}}=-1.015 \cdot 10^{5} \quad \mathrm{y}_{\mathrm{S}}=0.000384 \\
& \mathrm{~N}_{2} \quad \mathrm{~N}_{\mathrm{A}}=3.280 \quad \mathrm{~N}_{\mathrm{B}}=0.593 \cdot 10^{-3} \quad \mathrm{~N}_{\mathrm{D}}=0.040 \cdot 10^{5} \quad \mathrm{y}_{\mathrm{N}}=0.7496 \\
& \mathrm{O}_{2} \quad \mathrm{O}_{\mathrm{A}}=3.639 \quad \mathrm{O}_{\mathrm{B}}=0.506 \cdot 10^{-3} \quad \mathrm{O}_{\mathrm{D}}=-0.227 \cdot 10^{5} \quad \mathrm{y}_{\mathrm{O}}=0.1305 \\
& M W_{C}=44.01 \mathrm{~g} / \mathrm{gmole} \\
& M W_{H}=18.02 \mathrm{~g} / \mathrm{gmole} \\
& \mathrm{MW}_{\mathrm{S}}=64.06 \mathrm{~g} / \mathrm{gmole} \\
& \mathrm{y}=\mathrm{y}_{\mathrm{C}}+\mathrm{y}_{\mathrm{H}}+\mathrm{y}_{\mathrm{S}}+\mathrm{y}_{\mathrm{O}}+\mathrm{y}_{\mathrm{N}} \\
& y=1 \\
& M W_{N}=28.02 \mathrm{~g} / \mathrm{gmole} \\
& \mathrm{MW}_{\mathrm{O}}=32.00 \mathrm{~g} / \mathrm{gmole} \\
& \mathrm{R}=8.314 \frac{\text { joule }}{\text { gmole } \cdot \mathrm{K}} \\
& \mathrm{T}=387 \mathrm{~K}=697 \mathrm{R} \quad \text { Temperature of flue gas exiting the baghouse }
\end{aligned}
$$

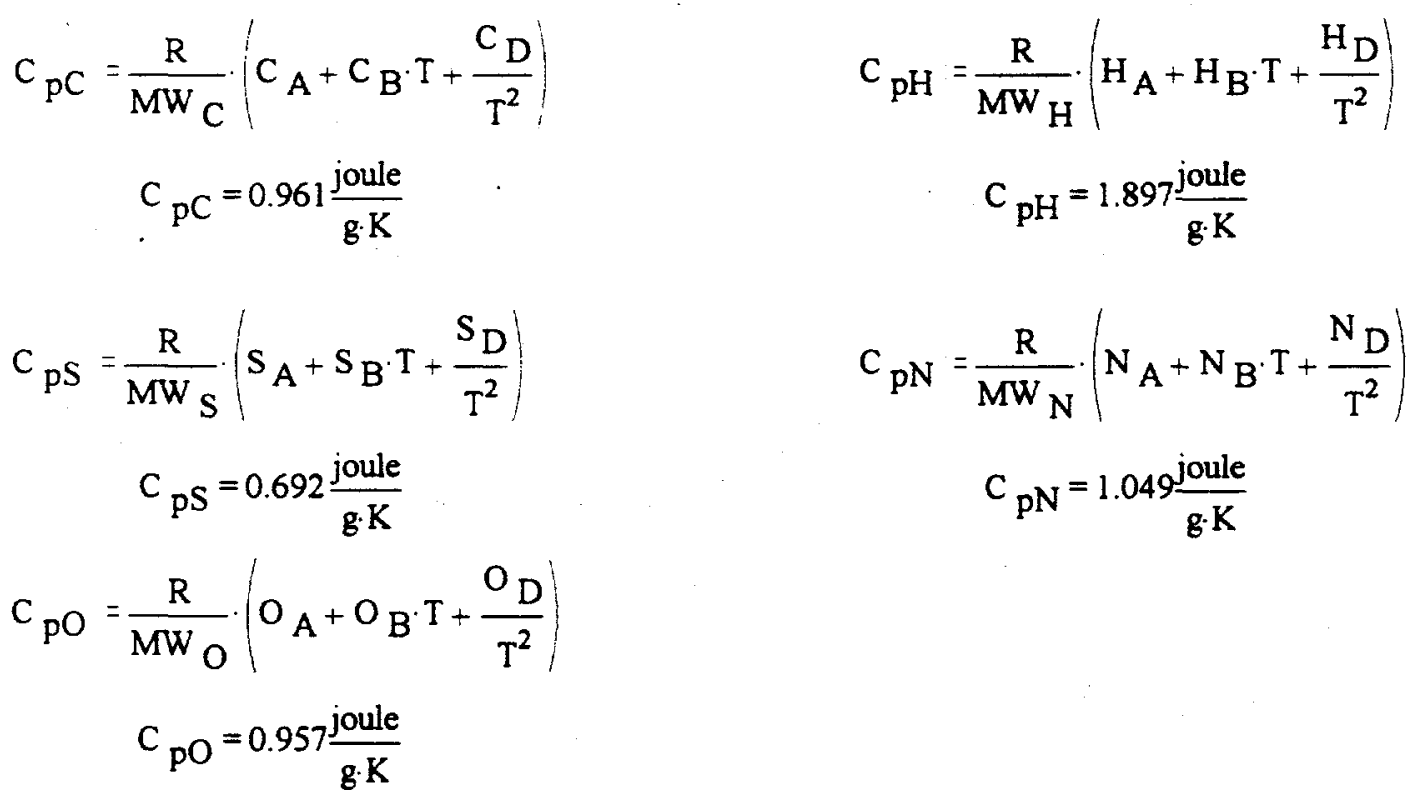




$$
\begin{gathered}
\mathrm{C}_{\text {pMixture }}=\mathrm{y}_{\mathrm{C}} \cdot \mathrm{C}_{\mathrm{pC}}+\mathrm{y}_{\mathrm{H}} \mathrm{C}_{\mathrm{pH}}+\mathrm{y}_{\mathrm{S}} \cdot \mathrm{C}_{\mathrm{pS}}+\mathrm{y}_{\mathrm{N}} \cdot \mathrm{C}_{\mathrm{pN}}+\mathrm{y}_{\mathrm{O}} \cdot \mathrm{C}_{\mathrm{pO}} \\
\mathrm{C}_{\text {pMixture }}=1.082 \frac{\mathrm{joule}}{\mathrm{g} \cdot \mathrm{K}}=0.261 \frac{\mathrm{BTU}}{\mathrm{lb} \cdot \mathrm{R}}
\end{gathered}
$$

Determining Heat Capacity of Air:

$\mathrm{T}=749.4 \mathrm{~K}=1349 \mathrm{R} \quad$ Average temperature of air through the air heater

$$
\begin{aligned}
& \text { Air } \quad A_{A}=3.355 \quad A_{B}=0.575 \cdot 10^{-3} \quad A_{D}=-0.016 \cdot 10^{5} \quad M_{\text {Air }}=29 \mathrm{~g} / \mathrm{gmole} \\
& \mathrm{C}_{\mathrm{pAir}}=\frac{\mathrm{R}}{\mathrm{MW} \text { Air }} \cdot\left(\mathrm{A}_{\mathrm{A}}+\mathrm{A}_{\mathrm{B}} \cdot \mathrm{T}+\frac{\mathrm{A}_{\mathrm{D}}}{\mathrm{T}^{2}}\right) \\
& \mathrm{C}_{\text {pAir }}=1.085 \frac{\text { joule }}{\mathrm{g} \cdot \mathrm{K}}=0.259 \frac{\mathrm{BTU}}{\mathrm{lb} \cdot \mathrm{R}}
\end{aligned}
$$


Turbine Calculations ${ }^{20}$

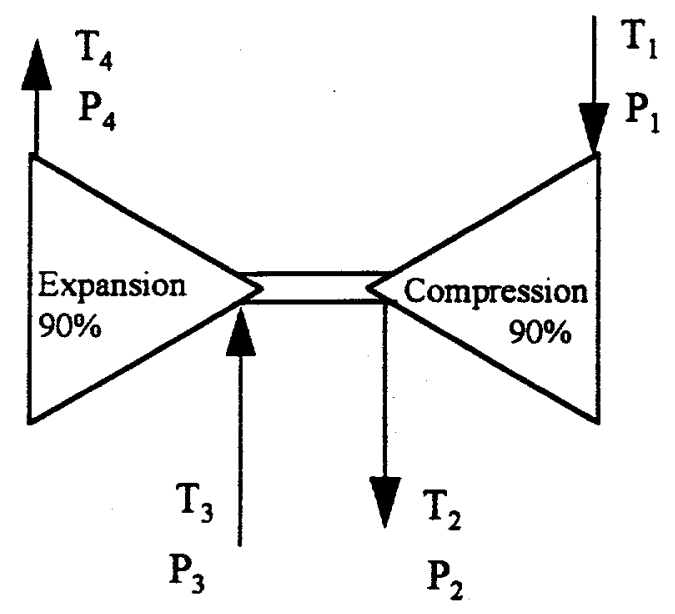

Properties of Air

$\begin{array}{lll}\mathrm{Cp}_{\text {air }}=0.259 \cdot \frac{\mathrm{BTU}}{\mathrm{lb} \cdot \mathrm{R}} & \mathrm{P}_{1}=1 \cdot \mathrm{atm} & \mathrm{T}_{1}:=530 \cdot \mathrm{R} \\ \mathrm{P}_{2}=4 \cdot \mathrm{atm} & \\ \mathrm{P}=1.4 & \mathrm{P}_{3}=4 \cdot \mathrm{atm} & \mathrm{T}_{3}:=1910 \cdot \mathrm{R} \\ \mathrm{P}_{4}=1 \cdot \mathrm{atm} & \end{array}$

Mechanical Efficiency of Turbine and Compressor

$$
\begin{aligned}
& \eta_{t}=90 \% \\
& \eta_{c}=90 \%
\end{aligned}
$$

Calculations for $T_{2}$ and $T_{4}$

$$
\begin{aligned}
& T_{2}=T_{1} \cdot\left(\frac{P_{2}}{P_{1}}\right)^{\frac{k-1}{k}} \\
& T_{2}=787.6 \cdot R \\
& T_{2}=327.6^{\circ} \mathrm{F}
\end{aligned}
$$$$
T_{4}=\frac{T_{3}}{\left(\frac{P_{2}}{P_{1}}\right)^{\frac{k-1}{k}}}
$$$$
\mathrm{T}_{4}=1.285 \cdot 10^{3} \cdot \mathrm{R}
$$$$
\mathrm{T} 4=825^{\circ} \mathrm{F}
$$ 
Work produced by Turbine $\left(W_{t}\right)$

$$
\mathrm{w}_{\mathrm{t}}:=\left[\mathrm{Cp}_{\text {air }} \cdot\left(\mathrm{T}_{3}-\mathrm{T}_{4}\right)\right] \cdot \eta_{\mathrm{t}} \quad \mathrm{W}_{\mathrm{t}}=145.609 \cdot \frac{\mathrm{BTU}}{\mathrm{lb}}
$$

Shaft work required by compressor $\left(W_{c}\right)$

$W_{c}=\frac{C_{p_{a i r}}\left(T_{1}-T_{2}\right)}{\eta_{c}}$

$$
\mathrm{W}_{\mathrm{c}}=-74.125 \cdot \frac{\mathrm{BTU}}{\mathrm{lb}}
$$

Net work produced by the turbine $\left(W_{n}\right)$

$$
\mathrm{w}_{\mathrm{n}}=\mathrm{w}_{\mathrm{t}}+\mathrm{W}_{\mathrm{c}} \quad \mathrm{W}_{\mathrm{n}}=71.485 \cdot \frac{\mathrm{BTU}}{\mathrm{lb}}
$$

Heat addition per unit mass of air $\left(q_{a}\right)$

$$
\mathrm{q}_{\mathrm{a}}=\mathrm{Cp}_{\mathrm{air}} \cdot\left(\mathrm{T}_{3}-\mathrm{T}_{2}\right) \quad \mathrm{q}_{\mathrm{a}}=290.708 \cdot \frac{\mathrm{BTU}}{\mathrm{lb}}
$$

Thermal Efficiency

$$
\eta_{\text {th }}=\frac{w_{n}}{q_{a}} \quad \eta_{\text {th }}=24.59 \cdot \%
$$

Ratio of Turbine Work to Compressor Work

$$
\text { Ratio }=\frac{w_{t}}{\left|W_{c}\right|} \quad \text { Ratio }=1.964
$$


Mass of air needed to produce required electrical load

$m_{\text {air }}:=\frac{41370 \cdot \frac{\mathrm{kW} \cdot \mathrm{hr}}{\mathrm{day}}}{\mathrm{W}_{\mathrm{n}}}$

$$
\mathrm{m}_{\text {air }}=1.975 \cdot 10^{6} \cdot \frac{\mathrm{lb}}{\mathrm{day}}
$$

Mass of water/glycol stream required for district heating

$\mathrm{m}_{\mathrm{wg}}=\frac{15000000 \cdot \frac{\mathrm{BTU}}{\mathrm{hr}}}{0.87 \cdot \frac{\mathrm{BTU}}{\mathrm{lb} \cdot \mathrm{R}} \cdot 20 \cdot \mathrm{R}}$

$$
\mathrm{m}_{w g}=2.069 \cdot 10^{7} \cdot \frac{\mathrm{lb}}{\text { day }}
$$

Heat capacity of the flue gas

$$
\mathrm{C}_{\mathrm{fg}}=0.261 \cdot \frac{\mathrm{BTU}}{\mathrm{lb} \cdot \mathrm{R}} \quad \Delta \mathrm{T}:=696 \cdot \mathrm{R}
$$

Mass flow rate of flue gas, which was obtained using a Lotus spreadsheet.

$$
\mathrm{m}_{\mathrm{fg}}=101911 \cdot \frac{\mathrm{lb}}{\mathrm{hr}}
$$

Amount of energy entering the atmosphere, through the stack:

$E_{\text {stack }}=m_{f g} \cdot C_{P_{f g}} \cdot \Delta T$

$$
E_{\text {stack }}=4.443 \cdot 10^{8} \cdot \frac{\mathrm{BTU}}{\text { day }}
$$

Energy needed to heat air from 788R to 1910R:

$E_{\text {electricity }}=m_{\text {air }} \cdot C_{p_{\text {air }}} \cdot\left(T_{3}-T_{2}\right)$

$$
E_{\text {electricity }}=5.741 \cdot 10^{8} \cdot \frac{\mathrm{BTU}}{\mathrm{day}}
$$


Total energy leaving the system:

$E_{\text {heating }}:=3.6 \cdot 10^{8} \cdot \frac{\mathrm{BTU}}{\text { day }}$

$E_{\text {total }}=E_{\text {electricity }}+E_{\text {heating }}+E_{\text {stack }}$

$$
E_{\text {total }}=1.378 \cdot 10^{9} \cdot \frac{\mathrm{BTU}}{\mathrm{day}}
$$

AFBC efficiency

$$
\eta_{\mathrm{AFBC}}=80 \%
$$

Required energy generated in AFBC

$E_{\text {AFBC }}=\frac{E_{\text {total }}}{\eta_{\text {AFBC }}}$

$E_{\mathrm{AFBC}}=1.723 \cdot 10^{9} \cdot \frac{\mathrm{BTU}}{\text { day }}$

Energy from air streams:

$$
\begin{gathered}
\mathrm{m}_{\text {excessair }}=3214 \cdot \frac{\mathrm{ft}^{3}}{\mathrm{~min}} \quad \mathrm{p}_{\text {air }}=0.0808 \cdot \frac{\mathrm{lb}}{\mathrm{ft}^{3}} \quad \mathrm{~T}_{\text {ref }}=0 \cdot \mathrm{R} \\
\mathrm{Cp}_{\text {excessair }}=0.24 \cdot \frac{\mathrm{BTU}}{\mathrm{lb} \cdot \mathrm{R}} \quad \mathrm{T}_{\text {excessair }}=655 \cdot \mathrm{R} \\
\mathrm{E}_{\text {air }}=\mathrm{m}_{\text {air }} \cdot \mathrm{Cp}_{\text {air }} \cdot\left(\mathrm{T}_{4}-\mathrm{T}_{\text {ref }}\right)+\mathrm{m}_{\text {excessair }} \cdot \rho_{\text {air }} \cdot \mathrm{Cp}_{\text {excessair }}\left(\mathrm{T}_{\text {excessair }}-\mathrm{T}_{\text {ref }}\right) \\
\mathrm{E}_{\text {air }}=7.162 \cdot 10^{8} \cdot \frac{\mathrm{BTU}}{\mathrm{day}}
\end{gathered}
$$

Energy required by fuel

$$
E_{\text {fuel }}=E_{A F B C}-E_{\text {air }}
$$

$$
E_{\text {fuel }}=4.195 \cdot 10^{7} \cdot \frac{\mathrm{BTU}}{\mathrm{hr}}
$$


Amount of coal required

$$
\begin{aligned}
& \text { Heating Values } \\
& \mathrm{HV}_{\text {wood }}=8900 \cdot \frac{\mathrm{BTU}}{\mathrm{lb}} \\
& \mathrm{HV}_{\mathrm{MSW}}=8484 \cdot \frac{\mathrm{BTU}}{\mathrm{Ib}} \\
& \mathrm{HV}_{\text {sludge }}:=6269 \cdot \frac{\mathrm{BTU}}{\mathrm{lb}} \\
& \text { Wood }=299 \cdot \frac{\text { ton }}{\mathrm{yr}} \\
& \mathrm{MSW}:=665 \cdot \frac{\text { ton }}{\mathrm{yr}} \\
& \text { Sludge }:=10.4 \cdot \frac{\text { ton }}{\mathrm{yr}} \\
& \mathrm{HV}_{\text {coal }}=9094 \cdot \frac{\mathrm{BTU}}{\mathrm{lb}} \\
& \text { Coal }=\frac{E_{\text {fuel }}-\text { Wood } \cdot H V_{\text {wood }}-M S W \cdot H V_{M S W}-\text { Sludge } \cdot H V_{\text {sludge }}}{H V_{\text {coal }}} \\
& \text { Coal }=1.9 \cdot 10^{4} \cdot \frac{\text { ton }}{\mathrm{yr}} \quad \mathrm{Coal}=52.84 \cdot \frac{\text { ton }}{\text { day }}
\end{aligned}
$$




\section{Energy Balances}

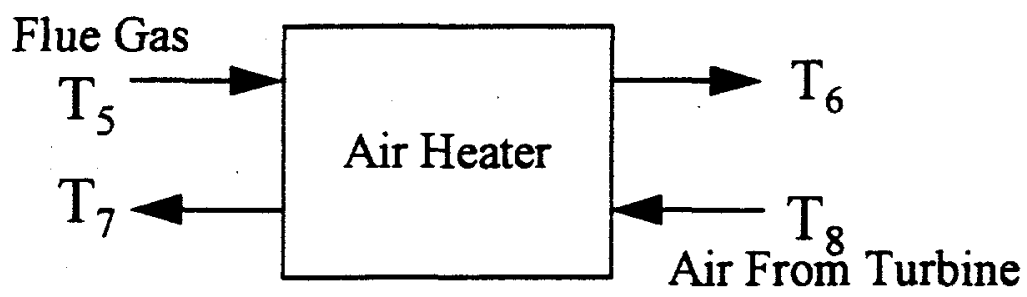

$$
\begin{array}{clc}
\mathrm{m}_{\mathrm{fg}}=2.446 \cdot 10^{6} \cdot \frac{\mathrm{lb}}{\mathrm{day}} & \mathrm{T}_{5}=2010 \cdot \mathrm{R} & \mathrm{Cp}_{\mathrm{fg}}=.289 \cdot \frac{\mathrm{BTU}}{\mathrm{lb} \cdot \mathrm{R}} \\
\mathrm{m}_{\mathrm{air}}=1.975 \cdot 10^{6} \cdot \frac{\mathrm{lb}}{\mathrm{day}} & \mathrm{T}_{7}=1900 \cdot \mathrm{R} & \mathrm{Cp}_{\mathrm{air}}=0.259 \cdot \frac{\mathrm{BTU}}{\mathrm{lb} \cdot \mathrm{R}} \\
\mathrm{T}_{8}=788 \cdot \mathrm{R} & \\
\mathrm{T}_{6}=-\left[\frac{\mathrm{m}_{\mathrm{air}} \cdot \mathrm{Cp}_{\mathrm{air}} \cdot\left(\mathrm{T}_{7}-\mathrm{T}_{8}\right)}{\mathrm{m}_{\mathrm{fg}} \cdot \mathrm{Cp}_{\mathrm{fg}}}-\mathrm{T}_{5}\right] & \mathrm{T}_{6}=1.205 \cdot 10^{3} \cdot \mathrm{R}
\end{array}
$$

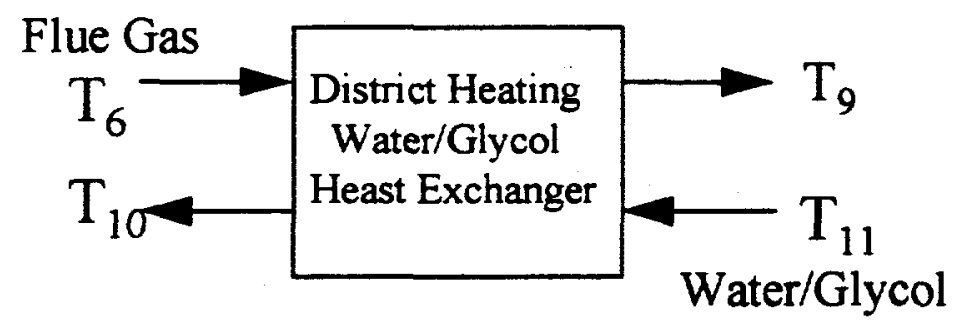

Heat capacity of $50 \%$ water/glycol solution ${ }^{9}$

$$
\begin{array}{ll}
\mathrm{T}_{10}=660 \cdot \mathrm{R} & \mathrm{Cp}_{\mathrm{wg}}{ }^{8}=0.87 \cdot \frac{\mathrm{BTU}}{\mathrm{lb} \cdot \mathrm{R}} \\
\mathrm{T}_{11}=640 \cdot \mathrm{R} &
\end{array}
$$

$T_{9}=-\left[\left[\frac{m_{w g} \cdot C_{w g} \cdot\left(T_{10}-T_{11}\right)}{m_{f g} \cdot C_{p_{f g}}}\right]-T_{6}\right]$

$$
T_{9}=696 \cdot R
$$


Determination of required limestone to reduce sulfur dioxide emissions by $90 \%$

Theoretical amount of $\mathrm{SO}_{2}$ formed by combustion

Average mass fraction of sulfur in coal

Average mass fraction of sulfur in MSW ${ }^{y_{\text {col }}}=0.0095$

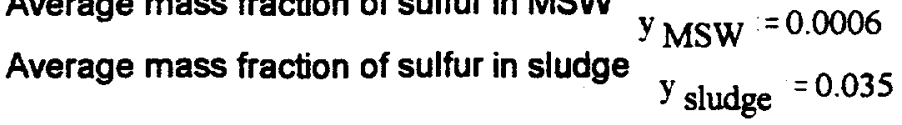

No sulfur was found to be present in the wood.

$$
\begin{gathered}
\mathrm{SO}_{2}=\mathrm{y}_{\text {coal }} \text { Coal }+\mathrm{y}_{\mathrm{MSW}} \mathrm{MSW}+\mathrm{y}_{\text {sludge }} \cdot \text { Wood } \\
\mathrm{SO}_{2}=1.063 \cdot 10^{3} \cdot \frac{\mathrm{lb}}{\text { day }}
\end{gathered}
$$

Amount of $\mathrm{SO}_{2}$ required to be removed to reduce emissions by $90 \%$

$$
\begin{aligned}
& \mathrm{SO}_{2 \mathrm{req}}=0.90 \cdot \mathrm{SO}_{2} \\
& \mathrm{SO}_{2 \mathrm{req}}=957.024 \cdot \frac{\mathrm{lb}}{\mathrm{day}}
\end{aligned}
$$

Reactions involved in the removal of $\mathrm{SO}_{2}$

$$
\begin{aligned}
& \mathrm{CaCO}_{3} \rightarrow \mathrm{CaO}+\mathrm{CO}_{2} \quad \text { approximately } 60 \% \text { conversion } 4 \\
& \mathrm{CaO}+\mathrm{SO}_{2}+1 / 2 \mathrm{O}_{2} \rightarrow \mathrm{CaSO}_{4} \quad \text { approximately } 40 \% \text { conversion } 4
\end{aligned}
$$

Required amount of $\mathrm{CaO}$

$$
\begin{aligned}
& \mathrm{CaO}=\frac{\mathrm{SO}_{2 \text { req }}}{0.4} \\
& \mathrm{CaO}=2.393 \cdot 10^{3} \cdot \frac{\mathrm{lb}}{\text { day }}
\end{aligned}
$$

Required amount of $\mathrm{CaCO}_{3}$

$$
\begin{aligned}
\mathrm{CaCO}_{3} & =\frac{\mathrm{CaO}}{0.6} \\
\mathrm{CaCO}_{3} & =3.988 \cdot 10^{3} \cdot \frac{\mathrm{lb}}{\mathrm{day}}
\end{aligned}
$$

Amount of limestone

The limestone being used is a calcitic limestone with $80 \% \mathrm{CaCO}_{3}$

$$
\text { Limestone }=\frac{\mathrm{CaCO}_{3}}{0.8} \quad \text { Limestone }=4.98 \cdot 10^{3} \cdot \frac{\mathrm{lb}}{\mathrm{day}}
$$




\section{Weighted Average Composition and Heating Value of Fuel}

\begin{tabular}{|c|c|c|c|c|c|}
\hline & $\begin{array}{l}\text { Coal" } \\
\frac{\text { (ton/yr) }}{19040}\end{array}$ & $\begin{array}{l}\frac{\text { MSW }}{\text { (ton/yr) }} \\
665\end{array}$ & $\begin{array}{l}\text { Wood } \\
\frac{299}{\text { (ton/yr) }}\end{array}$ & $\begin{array}{l}\text { Sludge } \\
\text { (ton/yr) } \\
10.4\end{array}$ & $\begin{array}{l}\text { Total Fuel } \\
\text { (ton/yr) } \\
20014.4\end{array}$ \\
\hline $\begin{array}{l}\text { Weight Fraction } \\
\text { of Total Fuel }\end{array}$ & 0.9513 & 0.0332 & 0.0149 & 0.0005 & \\
\hline Carbon & 53.91 & 44.05 & 52.55 & 31.6 & 53.55 \\
\hline Hydrogen & 3.43 & 4.66 & 6.02 & 4.4 & 3.51 \\
\hline Oxygen & 13.03 & 8.48 & 41.25 & 19.3 & 13.30 \\
\hline Nitrogen & 0.68 & 0.32 & & 3.9 & 0.66 \\
\hline Sulfur & 0.95 & 0.06 & & 3.5 & 0.91 \\
\hline Ash & 7.11 & 7.20 & 0.12 & 38.4 & 7.02 \\
\hline$\%$ Moisture & 21.19 & 35.23 & & 4 & 21.33 \\
\hline HV (BTU/lb) & 9094 & 8484 & 8900 & 6289 & 9069 \\
\hline
\end{tabular}

"Coal composition and heating value from Ashworth(2)

"*MSW and sludge compositions and heating values from Mann(5)

***Wood composition and heating value from Perry $(7)$ 


\begin{tabular}{|c|c|c|c|c|c|}
\hline $\begin{array}{c}\text { As-Received } \\
\text { Ultimate } \\
\text { analysis } \\
\% \rightarrow>\end{array}$ & 100.28 & $\begin{array}{l}\text { Total Sample } \\
100.28 \%\end{array}$ & $\begin{array}{l}\text { Theoretical } \\
\text { Ib air/lb coal }\end{array}$ & $\begin{array}{c}\text { As-Received } \\
\text { Ultimate } \\
\text { analysis } \\
\% \rightarrow\end{array}$ & In-put \\
\hline $\begin{array}{l}\text { Carbon } \\
\text { Hydrogen } \\
\text { Oxygen } \\
\text { Nitrogen } \\
\text { Sulfur } \\
\text { Ash } \\
\% \text { moisture }\end{array}$ & $\begin{array}{r}53.55 \\
3.51 \\
13.30 \\
0.66 \\
0.91 \\
7.02 \\
21.33\end{array}$ & $\begin{array}{r}53.40 \\
3.50 \\
13.26 \\
0.66 \\
0.91 \\
7.00 \\
21.27\end{array}$ & $\begin{array}{l}6.157 \\
1.202 \\
0.039\end{array}$ & $\begin{array}{r}53.55 \\
5.88 \\
32.26 \\
0.66 \\
0.91 \\
7.02 \\
21.33\end{array}$ & $\begin{array}{r}53.55 \\
3.51 \\
13.3 \\
0.66 \\
0.91 \\
7.02 \\
21.33\end{array}$ \\
\hline Total & $\begin{array}{l}100.3 \\
\text { Less oxygen in fuel: }\end{array}$ & 100.0 & $\begin{array}{l}7.398 \mathrm{Ib} \\
-0.573\end{array}$ & 100.28 & \\
\hline Total air requir & $\begin{array}{l}\text { d at } 195.0 \\
\text { Flow rate/lb coal }\end{array}$ & $\%$ excess air = & $\begin{array}{c}6.825 \mathrm{lb} \\
20.132 \mathrm{lb} \\
265.062 \mathrm{scf} / \mathrm{b} \mathrm{b}\end{array}$ & & \\
\hline $\begin{array}{l}\text { flue gas } \mathrm{O} 2 \\
\text { flue gas } \mathrm{CO} 2 \\
\text { Excess air }=\end{array}$ & & $\begin{array}{r}13.0 \% \\
6.0 \% \\
195.00 \%\end{array}$ & & & \\
\hline $\begin{array}{l}\text { Fuel feed rate: } \\
\text { Required air flo }\end{array}$ & & $\begin{array}{r}4569 \mathrm{lb} / \\
20184.46 \mathrm{sct}\end{array}$ & & & \\
\hline
\end{tabular}

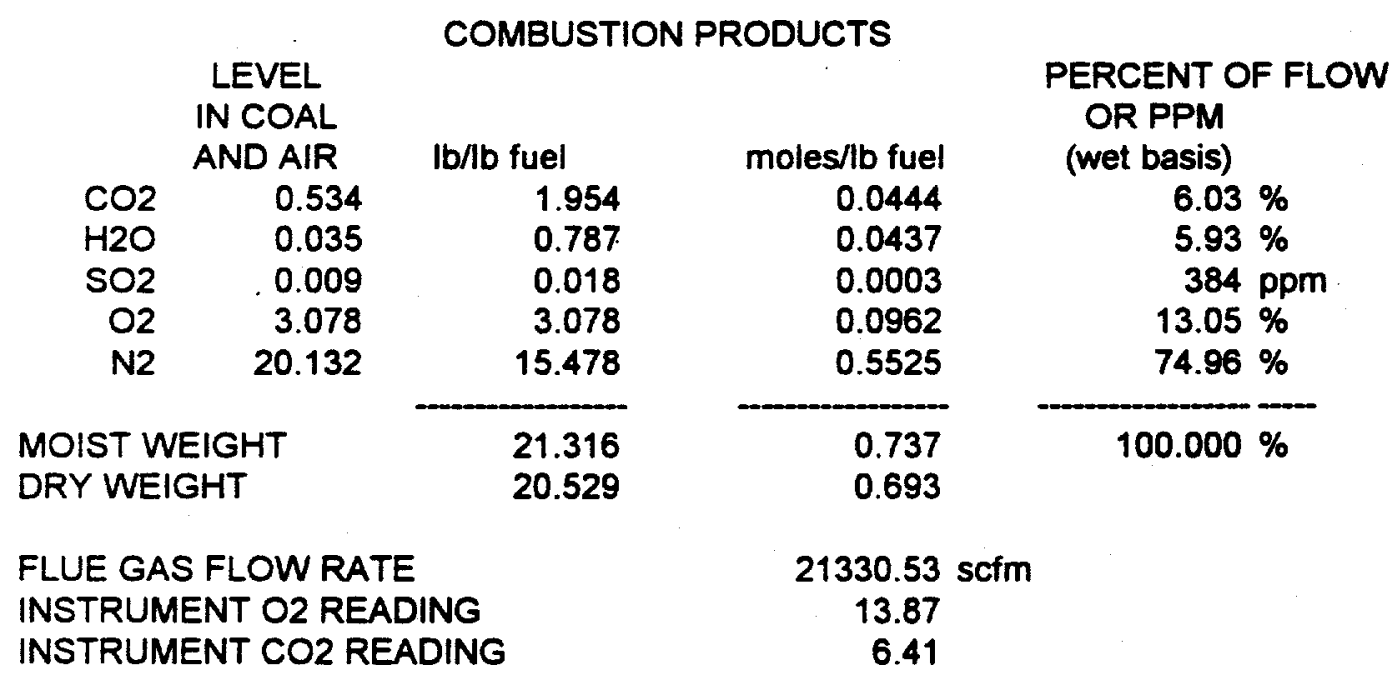


APPENDIX L: Equipment Design Calculations 


\section{SIZING THE ATMOSPHERIC FLUIDIZED BED COMBUSTOR (AFBC)}

Volumetric flow rate of flue gas (Nolinestand) at standard conditions ( $1 \mathrm{~atm}$ and $32^{\circ} \mathrm{F}$ ) necessary to generate average required power and heating demands:

Mass flow rate of flue gas, $\quad \mathrm{M}_{\text {flue }}=2.55 \cdot 10^{6} \cdot \frac{\mathrm{lb}}{\mathrm{day}}$

Density of flue gas at standard conditions ${ }^{8}$,

(assuming flue gas is essentially all air, approximately 96\%)

$$
\rho_{\text {flue }}=0.0808 \cdot \frac{\mathrm{lb}}{\mathrm{f}^{3}}
$$

$$
\begin{aligned}
& \text { Vol fluestand }:=\frac{M_{\text {flue }}}{\rho_{\text {flue }}} \\
& \qquad V_{\text {fluestand }}=365.271 \cdot \frac{\mathrm{f}^{3}}{\mathrm{sec}}
\end{aligned}
$$

Volumetric flow rate of flue gas corrected to AFBC temperature (1550\%):

Assumed at this high temperature, the flue gas behaves ideally.

$$
\begin{gathered}
V_{\text {flue }}=\text { Vol fluestand } \frac{459.67+1550}{32+459.67} \\
V_{\text {flue }}=1.493 \cdot 10^{3} \cdot \frac{\mathrm{ft}^{3}}{\mathrm{sec}}
\end{gathered}
$$

Determining the bed area of the AFBC:

Assume a fluidization velocity of $8 \mathrm{ft} / \mathrm{sec}$ based on previous research done by the Energy and Environmental Research Center.

$$
\begin{aligned}
& V_{\text {fluidization }}=8 \cdot \frac{\mathrm{f}}{\mathrm{sec}} \\
& \text { Area }_{\text {bed }}=\frac{\mathrm{Vol}_{\text {flue }}}{\mathrm{V}_{\text {fluidization }}} \\
& \text { Area }_{\text {bed }}=186.6 \cdot \mathrm{f}^{2}
\end{aligned}
$$




\section{Sizing the Raw Material Feed Hoppers}

Coal Hopper:

Coal consumption, Coal $=104300 \cdot \frac{\mathrm{lb}}{\mathrm{day}}$

Storage capacity, Stor coal $=1$ day

Bulk density of coal ${ }^{8}$,

$$
\rho_{\text {coal }}=850 \cdot \frac{\mathrm{kg}}{\mathrm{m}^{3}}
$$

Coal hopper volume, Hoppervol coal $:=\frac{\text { Coal } \cdot \text { Stor coal }}{\rho_{\text {coal }}}$

$$
\text { Hoppervol }_{\text {coal }}=2 \cdot 10^{3} \cdot \mathrm{ft}^{3}
$$

Limestone Hopper:

Limestone consumption, Limestone $=4980 \cdot \frac{\mathrm{lb}}{\mathrm{day}}$

Storage capacity, Stor limestone $=2$-day

Bulk density of limestone ${ }^{8}$,

$$
\rho_{\text {limestone }}:=1500 \cdot \frac{\mathrm{kg}}{\mathrm{m}^{3}}
$$

Limestone Hopper volume, Hoppervol limestone $=\frac{\text { Limestone } \cdot \text { Stor limestone }}{\rho \text { limestone }}$

$$
\text { Hoppervol limestone }=106.4 \cdot \mathrm{ft}^{3}
$$

Municipal Solid Waste (MSW) Hopper:

MSW consumption, $\quad M S W=3644 \cdot \frac{\mathrm{lb}}{\mathrm{day}}$

Storage capacity, $\quad$ Stor $M S W=2 \cdot$ day

Bulk density of MSWB, $\quad \rho_{M S W}=130 \cdot \frac{\mathrm{kg}}{\mathrm{m}^{3}}$

MSW Hopper volume, Hoppervol $\mathrm{MSW}=\frac{\mathrm{MSW} \cdot \mathrm{Stor} \mathrm{MSW}}{\rho_{\mathrm{MSW}}}$

Hoppervol $_{\mathrm{MSW}}=898 \cdot \mathrm{ft}^{3}$ 
Wood Hopper:

Wood consumption, Wood $=1638 \cdot \frac{\mathrm{lb}}{\text { day }}$

Storage capacity, $\quad$ Stor wood $=2 \cdot$ day

Bulk density of wood ${ }^{8}$,

$$
\rho_{\text {wood }}=240 \cdot \frac{\mathrm{kg}}{\mathrm{m}^{3}}
$$

Wood Hopper volume, Hoppervol wood $=\frac{\text { Wood Stor wood }}{\rho_{\text {wood }}}$

$$
\text { Hoppervol }{ }_{\text {wood }}=219 \cdot \mathrm{ft}^{3}
$$

\section{Combined MSW and Wood Hopper}

Since the MSW and wood will be stored in the same hopper, their individual volumes need to be added together to find the required volume of the combined hopper.

Combined hopper volume Hopper combined $=$ Hoppervol $\mathrm{MSW}+$ Hoppervol wood

$$
\text { Hopper }_{\text {combined }}=1.1 \cdot 10^{3} \cdot \mathrm{ft}^{3}
$$

Sludge Hopper:

Sludge consumption, $\quad$ Sludge $=57 \cdot \frac{\mathrm{lb}}{\mathrm{day}}$

Storage capacity, $\quad$ Stor sludge $=2 \cdot$ day

Bulk density of sludge ${ }^{8}$,

$$
\rho_{\text {sludge }}=1000 \cdot \frac{\mathrm{kg}}{\mathrm{m}^{3}}
$$

Sludge Hopper volume, Hoppervol sludge $=\frac{\text { Sludge } \text { Stor } \text { sludge }}{\rho_{\text {sludge }}}$

$$
\text { Hoppervol sludge }=1.8 \cdot \mathrm{f}^{3}
$$


Fly Ash Storage from Cyclone:

Fly ash production, $\quad$ Flyash $\mathrm{cyc}=7177 \cdot \frac{\mathrm{lb}}{\mathrm{day}}$

Storage capacity, $\quad$ Stor cyc $=2 \cdot$ day

Bulk density of fly ash ${ }^{8}, \quad \quad \rho_{\text {flyash }}=745 \cdot \frac{\mathrm{kg}}{\mathrm{m}^{3}}$

Fly ash storage volume, Storagevol cyc $:=\frac{\text { Flyash }_{\text {cyc }} \text { Stor cyc }}{\rho_{\text {flyash }}}$

$$
\text { Storagevol }{ }_{\mathrm{cyc}}=309 \cdot \mathrm{ft}^{3}
$$

Fly Ash Storage from Baghouse:

Fly ash production, $\quad$ Flyash $_{\text {bag }}=790 \cdot \frac{\mathrm{lb}}{\text { day }}$

Storage capacity, $\quad$ Stor $_{\text {bag }}=2 \cdot$ day

Fly ash storage volume, $\quad$ Storagevol $_{\text {bag }}=\frac{\text { Flyash }_{\text {bag }} \cdot \text { Stor }_{\text {bag }}}{\rho_{\text {flyash }}}$

$$
\text { Storagevol }_{\text {bag }}=34 \cdot \mathrm{ft}^{3}
$$

\section{Sizing the Storage Facility for Limestone \\ (One Month Supply Stored)}

Limestone Bin:

Limestone consumption in one month, $\quad$ Lime $=144000 \cdot \mathrm{lb}$

Bulk density of limestone, $\quad P_{\text {lime }}=1500 \cdot \frac{\mathrm{kg}}{\mathrm{m}^{3}}$

Limestone storage bin volume, Binvol limestone $:=\frac{\text { Lime }}{\rho_{\text {lime }}}$

Binvol limestone $=1.5 \cdot 10^{3} \cdot \mathrm{ft}^{3}$ 


\section{Sizing the Fan to Provide Excess Air to AFBC}

In order to size the fan, three items of information must be known. They are the density of air at the fan, the air volumetric flow rate through the fan, and the fan static pressure (FSP) increase to be supplied.

$$
\begin{aligned}
& \text { Density of air at fan }\left(70^{\circ} \mathrm{F}\right), \quad \rho_{\text {air }}:=0.07519 \cdot \frac{\mathrm{lb}}{\mathrm{ft}^{3}} \\
& \text { Volumetric flow rate of air, } \quad \mathrm{Vol}_{\text {air }}=5310 \cdot \frac{\mathrm{fl}^{3}}{\mathrm{~min}}
\end{aligned}
$$

The FSP is found by calculating the head loss due to friction through the 50 feet of pipe leading from the fan to the AFBC and the acceleration loss that comes from accelerating stationary ambient air to the duct velocity. There will be no fittings or expansions and therefore no losses due to friction. For a low density gas such as air, a good duct velocity was found to be $\mathbf{2 5 0 0}$ $\mathrm{ft} / \mathrm{min}$.

First find cross-sectional area of the pipe and then its diameter.

$$
\begin{aligned}
& \text { Velocity of air in duct, } \quad v_{\text {air }}=2500 \cdot \frac{\mathrm{ft}}{\mathrm{min}} \\
& \text { Cross-sectional area of duct, } \quad A_{\text {duct }}=\frac{\mathrm{Vol}_{\text {air }}}{\mathrm{v}_{\text {air }}} \\
& \qquad \mathrm{A}_{\text {duct }}=2.124 \cdot \mathrm{ft}^{2} \\
& \text { Diameter of duct, } \quad D_{\text {duct }}=\sqrt{\frac{4 \cdot \mathrm{A}_{\text {duct }}}{\pi}} \\
& \cdot \mathrm{D}_{\text {duct }}=20 \cdot \text { in }
\end{aligned}
$$

The friction loss per 100 feet of pipe was then found from a chart using the volumetric flow rate, air velocity, and pipe diameter.

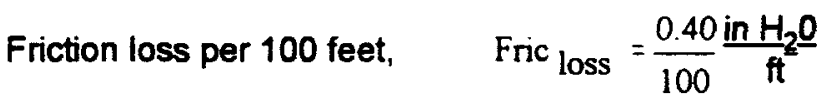

$$
\begin{aligned}
& \text { Length of pipe, Length pipe }=50 \mathrm{ft}
\end{aligned}
$$

Friction loss through 50 feet of pipe, Friction loss $=$ Fric $_{\text {loss }}$. Length $_{\text {pipe }}$

$$
\text { Friction loss }=0.2 \text { in } \mathrm{H}_{2} \mathrm{O}
$$


The friction loss due to acceleration of stationary ambient air to $2500 \mathrm{ft} / \mathrm{min}$ was then found.

$$
\text { Acceleration loss, } \quad \begin{aligned}
& A_{\text {loss }}=\left(\frac{v_{\text {air }}}{4005}\right)^{2} \\
& A_{\text {loss }}=0.39 \text { in } \mathrm{H}_{2} \mathrm{O}
\end{aligned}
$$

where the velocity of air must be in feet per minute and the acceleration loss is given in inches of water.

The fan static pressure was then found.

$$
\begin{aligned}
\text { Fan static pressure, } & \text { FSP }=A_{\text {loss }}+\text { Friction loss } \\
\text { FSP } & =0.59 \text { in } \mathrm{H}_{2} \mathrm{O}
\end{aligned}
$$

Fan rating tables were then used to find the specifications of a fan capable of providing $5310 \mathrm{ft}^{3} /$ min. Interpolation in these tables using the calculated FSP and volumetric flow rate showed that a 20 SISW (single inlet, single width) fan operating at $1330 \mathrm{RPM}$ with a $2 \mathrm{hP}$ motor is required. The specific type of fan that will be used is a backward inclined blade fan (a type of centrifugal fan) since it is efficient and reduces erosion from light dust in the air. 


\section{Pump Calculations}

Pump (L410)

Calculations will be based on 150 feet of head and a pump efficiency $(\eta)$ of $60 \%$

$$
\begin{aligned}
& \text { Head }=150 \cdot f \cdot \frac{\mathrm{lbf}}{\mathrm{lb}} \\
& \eta=0.60 \quad \mathrm{~W}_{\text {in }}=\frac{\text { Head }}{\eta}
\end{aligned}
$$

Power is calculated by $P=$ mass flow rate * work in

$$
\begin{aligned}
& \mathrm{m}:=8.6208 \cdot 10^{5} \cdot \frac{\mathrm{lb}}{\mathrm{hr}} \\
& \mathrm{m}=239.467 \cdot \frac{\mathrm{lb}}{\mathrm{sec}} \\
& \mathrm{P}=\mathrm{m} \cdot \mathrm{W}_{\text {in }} \\
& \mathrm{P}=109 \cdot \mathrm{hp}
\end{aligned}
$$

Pump (L600)

Calculations will be based on 70 feet of head and a pump efficiency $(\eta)$ of $60 \%$

$$
\begin{gathered}
\text { Head }=75 \cdot \mathrm{ft} \cdot \frac{\mathrm{lbf}}{\mathrm{lb}} \quad \eta=0.60 \\
\mathrm{~W}_{\text {in }}=\frac{\text { Head }}{\eta}
\end{gathered}
$$

Power is calculated by $P=$ mass flow rate * work in

$$
\begin{array}{ll}
\mathrm{m}=500510 \cdot \frac{\mathrm{lb}}{\mathrm{day}} & \mathrm{P}=\mathrm{m} \cdot \mathrm{W}_{\text {in }} \\
\mathrm{m}=5.793 \cdot \frac{\mathrm{lb}}{\mathrm{sec}} & \mathrm{P}=\mathrm{l} \cdot \mathrm{hp}
\end{array}
$$


Pump (L670)

Calculations will be based on 30 feet of head and a pump efficiency $(\eta)$ of $60 \%$

$$
\begin{gathered}
\text { Head }:=30 \cdot \mathrm{fl} \cdot \frac{\mathrm{lbf}}{\mathrm{lb}} \quad \eta=0.60 \\
\mathrm{w}_{\text {in }}=\frac{\text { Head }}{\eta}
\end{gathered}
$$

Power is calculated by $P=$ mass flow rate * work in

$$
\begin{aligned}
& \mathrm{m}=957.2 \cdot \frac{\mathrm{lb}}{\mathrm{day}} \\
& \mathrm{m}=0.011 \cdot \frac{\mathrm{lb}}{\mathrm{sec}}
\end{aligned}
$$$$
\mathrm{P}=\mathrm{m} \cdot \mathrm{W}_{\text {in }}
$$$$
\mathrm{P}=1 \cdot 10^{-3} \cdot \mathrm{hp}
$$

A 0.01 hp pump will be used 


\section{Baghouse Calculations}

The total amount of material area required

$$
\begin{aligned}
& \mathrm{Q}=21331 \cdot \frac{\mathrm{ft}^{3}}{\min } \quad \mathrm{V}:=2 \cdot \frac{\mathrm{ft}}{\min } \\
& \mathrm{A}=\frac{\mathrm{Q}}{\mathrm{V}} \\
& \mathrm{A}=1.067 \cdot 10^{4} \cdot \mathrm{ft}^{2}
\end{aligned}
$$

A total of three compartments will be used in the baghouse. Each compartment will contain $5000 \mathrm{ft}^{2}$ of material. This will allow for one compartment to be shut down for cleaning while the other two compartments remain operational.

Area per bag

$L_{\text {bag }}=8 \cdot f t \quad d_{\text {bag }}=0.5 \cdot f t$

$$
\begin{aligned}
& A_{\text {bag }}=L_{\text {bag }} \cdot d_{b_{a g} \cdot \pi} \\
& A_{\text {bag }}=12.566 \cdot \mathrm{ft}^{2}
\end{aligned}
$$

Number of bags needed

$$
\begin{aligned}
& A_{\text {total }}=15000 \cdot \mathrm{ft}^{2} \\
& \mathrm{~N}_{\text {bags }}=\frac{A_{\text {total }}}{A_{\text {bag }}} \\
& \mathrm{N}_{\text {bags }}=1.194 \cdot 10^{3}
\end{aligned}
$$

Number of bags per compartment

$$
\begin{aligned}
& \mathrm{B}_{\text {compartment }}=\frac{\mathrm{N}_{\text {bags }}}{3} \\
& \mathrm{~B}_{\text {compartment }}=398
\end{aligned}
$$




\section{Conventional Cyclone Calculations}

Standard conventional cyclone dimension

$\mathrm{D}=0.5$

$$
\begin{array}{ll}
H:=\frac{0.5}{D} \cdot m & L_{b}=\frac{2}{D} \cdot m \\
L_{c}=\frac{2}{D} \cdot m & W=0.25 \cdot \frac{m}{D}
\end{array}
$$

Properties of the Flue Gas
$\mu=0.110 \cdot \frac{\mathrm{lb}}{\mathrm{hr} \cdot \mathrm{ft}}$
$\rho_{\mathrm{A}}=.00125 \cdot \frac{\mathrm{kg}}{\mathrm{m}^{3}}$

Density of Ash

$\rho_{\mathrm{p}}=745 \cdot \frac{\mathrm{kg}}{\mathrm{m}^{3}}$

Number of Effective Turns in the Cyclone

$$
\mathrm{N}_{\mathrm{e}}=\left(\frac{1}{\mathrm{H}}\right) \cdot\left(\mathrm{L}_{\mathrm{b}}+\frac{\mathrm{L}_{\mathrm{c}}}{2}\right) \quad \mathrm{N}_{\mathrm{e}}=6
$$

Velocity of Flue Gas

$$
f=21331 \cdot \frac{\mathrm{f}^{3}}{\min } \quad \mathrm{V}_{\mathrm{i}}=\frac{\mathrm{f}}{\mathrm{H} \cdot \mathrm{W}}
$$

$$
\mathrm{V}_{\mathrm{i}}=1.208 \cdot 10^{3} \cdot \frac{\mathrm{m}}{\mathrm{min}}
$$

Diameter of Particle Collected with $50 \%$ Efficiency

$$
d_{p c}=\left[\frac{9 \cdot \mu \cdot W}{2 \cdot \pi \cdot N_{e} \cdot V_{i} \cdot\left(\rho_{p}-\rho_{A}\right)}\right]^{\frac{1}{2}} \quad d_{p c}=1.902 \cdot 10^{-5} \mathrm{~m}
$$


Conventional Cyclone Calculations

$\begin{array}{cccccc}\begin{array}{c}\text { Particle Size } \\ \text { Range }(\mathbf{m m})\end{array} & \mathbf{d}_{\boldsymbol{p}}(\mathbf{m m}) & \mathbf{d}_{\boldsymbol{p}} / \mathbf{d}_{\boldsymbol{p}} & \eta_{j} & \mathbf{m}_{\mathbf{j}}(\%) & \eta_{\mathbf{j}} \mathbf{m}_{\mathbf{j}}(\%) \\ 0-44 & 22 & 1.157 & 0.572 & 13.40 & 7.668 \\ 44-74 & 59 & 3.102 & 0.906 & 26.70 & 24.19 \\ 74-150 & 112 & 5.889 & 0.972 & 14.50 & 14.09 \\ 150-300 & 225 & 11.83 & 0.993 & 16.30 & 16.18 \\ 300-600 & 450 & 23.66 & 0.998 & 14.10 & 14.07 \\ 600-900 & 750 & 39.43 & 0.999 & 5.500 & 5.496 \\ 900-1200 & 1050 & 55.21 & 1.000 & 3.800 & 3.799 \\ 1200< & 1300 & 68.35 & 1.000 & 5.700 & 5.699\end{array}$

$d_{p}=a v e r a g e$ particle size

$\eta_{\mathrm{j}}=$ efficiency for each particle size range

$\mathrm{mj}=$ mass fraction of particles in the particle size range 
ASPEN PLUS VER: PC-DOS REL: 9.2-1 INST: EERC-PC 03/06/97 PAGE 2

FLOWSHEET SECTION

FLOWSHEET CONNECTIVITY BY STREAMS

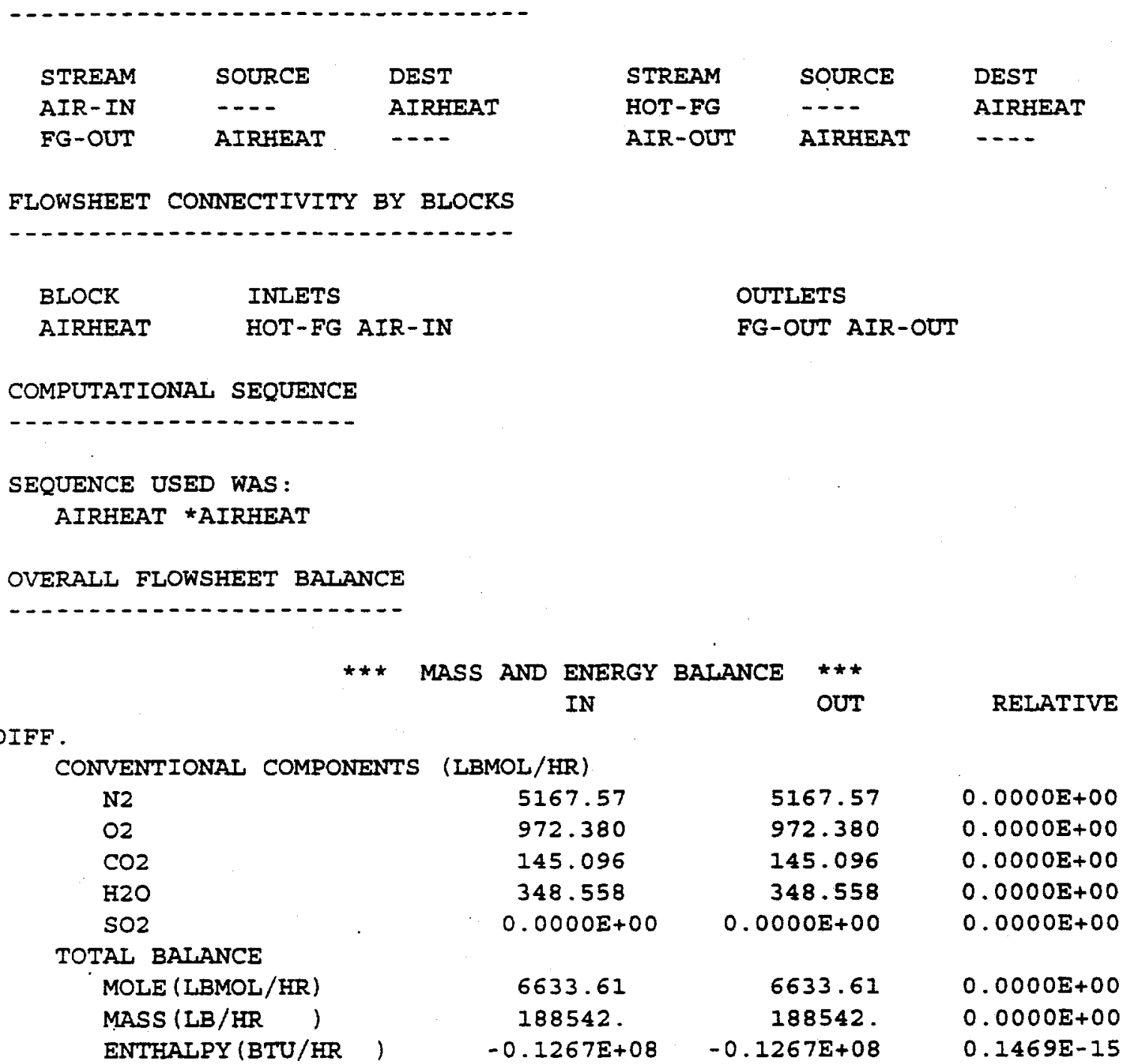


ASPEN PLUS VER: PC-DOS REL: 9.2-1 INST: EERC-PC 03/06/97 PAGE 5

\section{U-O-S BLOCK SECTION}

BLOCK: AIRHEAT MODEL: HEATX (CONTINUED)

HEAT TRANSFER COEFFICIENT SPECIFICATION:

$\begin{array}{llll}\text { HOT IIQUID } & \text { COLD LIQUID } & \text { BTU/HR-SQFT-R } & 149.6937 \\ \text { HOT 2-PHASE } & \text { COLD LIQUID } & \text { BTU/HR-SQFT-R } & 149.6937 \\ \text { HOT VAPOR } & \text { COLD LIQUID } & \text { BTU/HR-SQFT-R } & 149.6937 \\ \text { HOT LIQUID } & \text { COLD 2-PHASE } & \text { BTU/HR-SQFT-R } & 149.6937 \\ \text { HOT 2-PHASE } & \text { COLD 2-PHASE } & \text { BTU/HR-SQFT-R } & 149.6937 \\ \text { HOT VAPOR } & \text { COLD 2-PHASE } & \text { BTU/HR-SQFT-R } & 149.6937 \\ \text { HOT LIQUID } & \text { COLD VAPOR } & \text { BTU/HR-SQFT-R } & 149.6937 \\ \text { HOT 2-PHASE } & \text { COLD VAPOR } & \text { BTU/HR-SQFT-R } & 149.6937 \\ \text { HOT VAPOR } & \text { COLD VAPOR } & \text { BTU/HR-SQFT-R } & 149.6937\end{array}$

** * OVERAIL RESULTS ***

STREAMS :

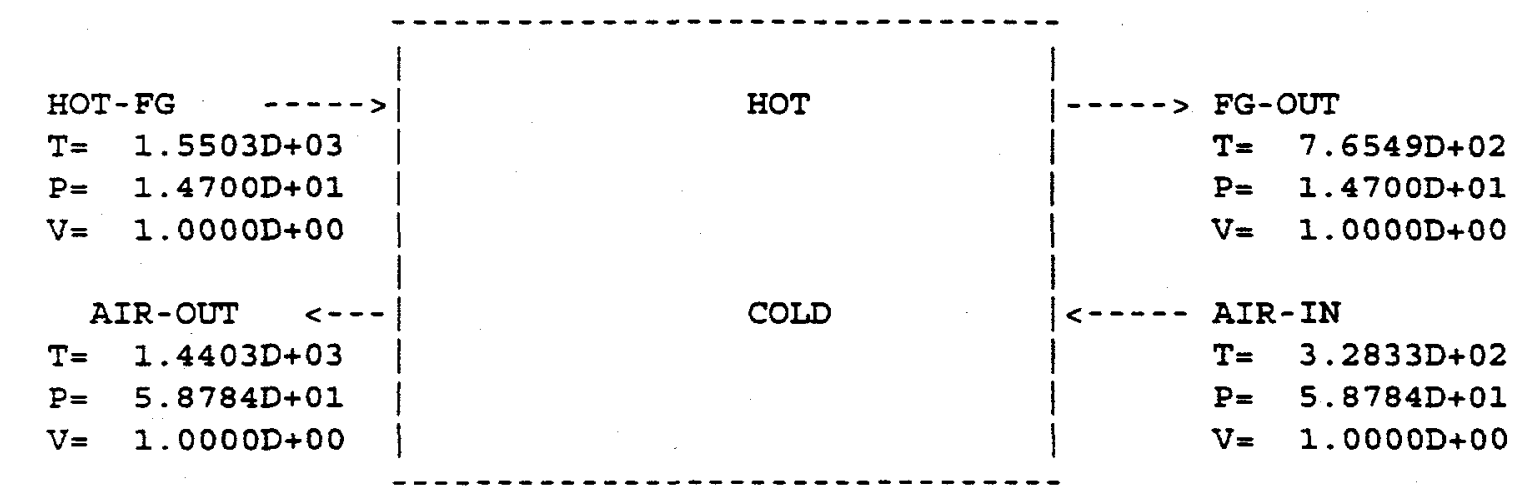

DUTY AND AREA:

$\begin{array}{lll}\text { CALCULATED HEAT DUTY } & \text { BTU/HR } & 23918828.7899 \\ \text { CALCULATED (REQUIRED) AREA } & \text { SQFT } & 673.9050\end{array}$

HEAT TRANSFER COEFFICIENT:

AVERAGE COEFFICIENT (DIRTY) BTU/HR-SQFT-R $\quad 149.6937$

LOG-MEAN TEMPERATURE DIFFERENCE :

IMTD CORRECTION FACTOR

LMTD (CORRECTED)

1.0000

PRESSURE DROP:

$\begin{array}{llr}\text { SHELLSIDE, TOTAL } & \text { PSI } & 0.0000 \\ \text { TUEESIDE, TOTAI } & \text { PSI } & 0.0000\end{array}$ 
ASPEN PLUS VER: PC-DOS REL: 9.2-I INST: EERC-PC 03/06/97 PAGE 6

$$
\text { U-O-S BLOCK SECTION }
$$

BLOCK: AIRHEAT MODEL: HEATX (CONTINUED)

$$
\star \star \star \text { ZONE RESULTS } \star \star \star
$$

TEMPERATURE LEAVING EACH ZONE:

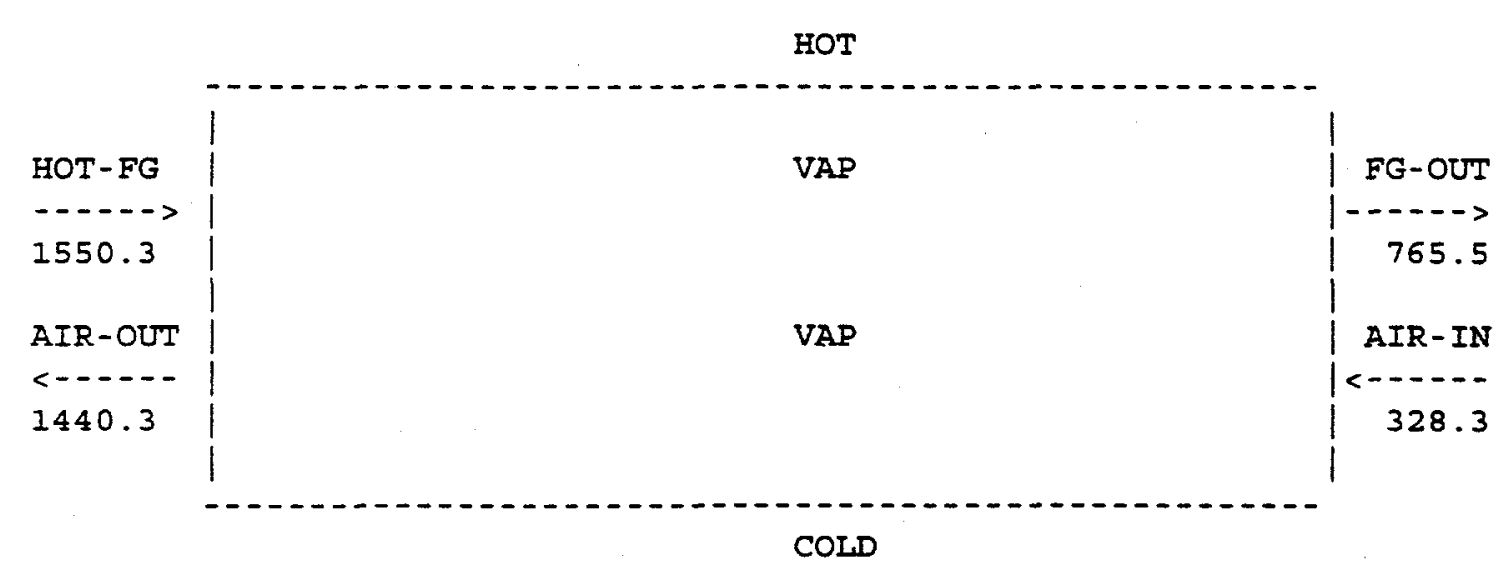

ZONE HEAT TRANSFER AND AREA:

$\begin{array}{lllll}\text { ZONE } & \text { HEAT DUTY } & \text { AREA } & \text { DTIM } & \text { AVERAGE U } \\ & \text { BTU/HR } & \text { SQFT } & \text { E } & \text { BTU/HR- }\end{array}$

SQFT-R

$1 \quad 23918828.790$

673.9050

237.1034

149.6937 
ASPEN PLUS VER: PC-DOS REL: $9.2-1 \quad$ INST: EERC-PC 03/06/97 PAGE 7

STREAM SECTION

AIR-IN AIR-OUT FG-OUT HOT-FG

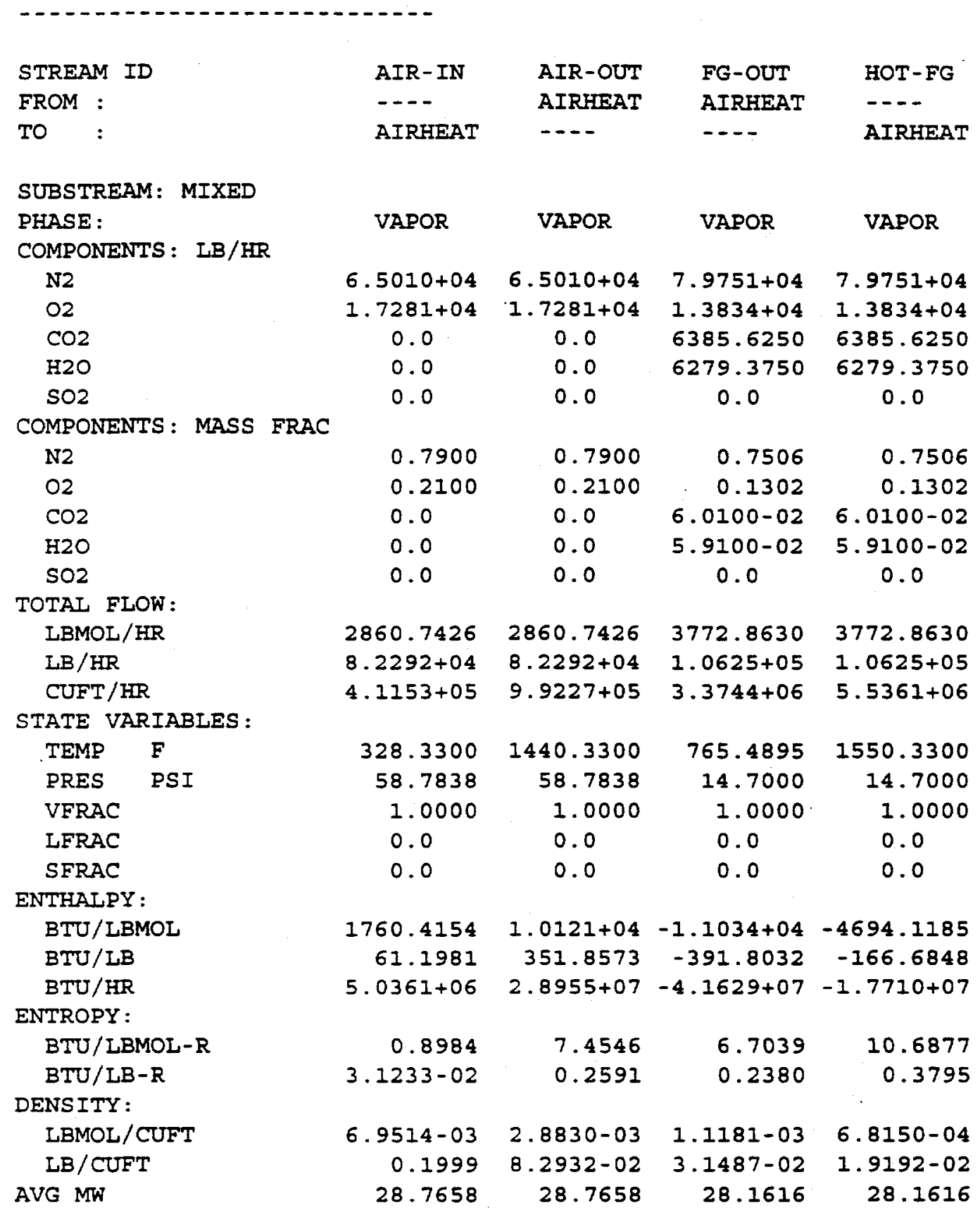


ASPEN PLUS VER: PC-DOS REL: $9.2-1 \quad$ INST: EERC-PC 03/06/97 PAGE 8

COST BLOCK SECTION

BLOCK: AIRHEAT MODEL : HEATX

BLOCK: AIRHEAT

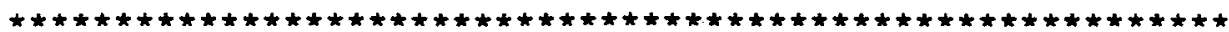

* WARNING: SIZING PARAMETER ABOVE CORRELATION IIMIT *

* PLEASE CHECK HISTORY FILE

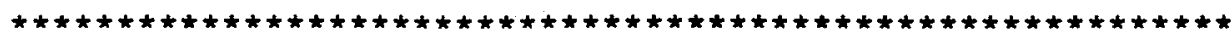

** INPUT DATA ***

HEAT EXCHANGER TYPE

BEM

SHELL MATERIAL

STAINLESS 316

TUBE MATERIAL

PEAK CAPACITY ALLOWANCE FACTOR

STAINLESS 316

NUMBER OF SHELL PASSES

SHELL PRESSURE

SHELI INLET TEMPERATURE

SHELL OUTLET TEMPERATURE

NUMBER OF TUBE PASSES

TUBE PRESSURE

TUBE INLET TEMPERATURE

TUBE OUTLET TEMPERATURE

FIOW DIRECTION

HEAT TRANSFER COEFFICIENT

1.06

QFT - R

** FLOWSHEET REFERENCE DATA ***

BLOCK ID - SHELI SIDE

AIRHEAT

BLOCK ID - TUBE SIDE

AIRHEAT

TOTAI HEAT TRANSFER AREA

673.9050

HEAT DUTY

CALCULATED NUMBER OF HEAT EXCHANGERS

1.95

MATERIAL OF CONSTRUCTION FACTOR

HEAT TRANSFER AREA PER UNIT

TOTAL SCALED HEAT DUTY

LOG MEAN TEMPERATURE DIFFERENCE

EXCHANGER GEOMETRY CORRECTION FACTOR

PSI

F

F

PSI

F

F

BTU/HR-

\section{$\star \star \star \operatorname{cosT}$ RESULTS $\star \star \star$}

CARBON STEEL COST

PURCHASED COST
$\$$

15,700

$\$ 30,700$ 
ASPEN PLUS VER: PC-DOS REL: $9.2-1 \quad$ INST: EERC-PC $03 / 06 / 97$ PAGE 2

\section{FLOWSHEET SECTION}

FLOWSHEET CONNECTIVITY BY STREAMS

$\begin{array}{llllll}\text { STREAM } & \text { SOURCE } & \text { DEST } & \text { STREAM } & \text { SOURCE } & \text { DEST } \\ \text { COLD-WG } & - & \text { BI } & \text { HOT-FG } & -\ldots & \text { BI } \\ \text { FG-OUT } & \text { BI } & -\ldots- & \text { WG-OUT } & \text { BI } & -. .\end{array}$

FLOWSHEET CONNECTIVITY BY BLOCKS

- - - - - - - - - - - - - - - - - - - - - -

BLOCK INLETS OUTLETS

B1 HOT-FG COLD-WG FG-OUT WG-OUT

COMPUTATIONAI SEQUENCE

-..-.-.-.-.-.-.-.-.-.-

SEQUENCE USED WAS :

BI DISTRICT

OVERAIL FLOWSHEET BALANCE

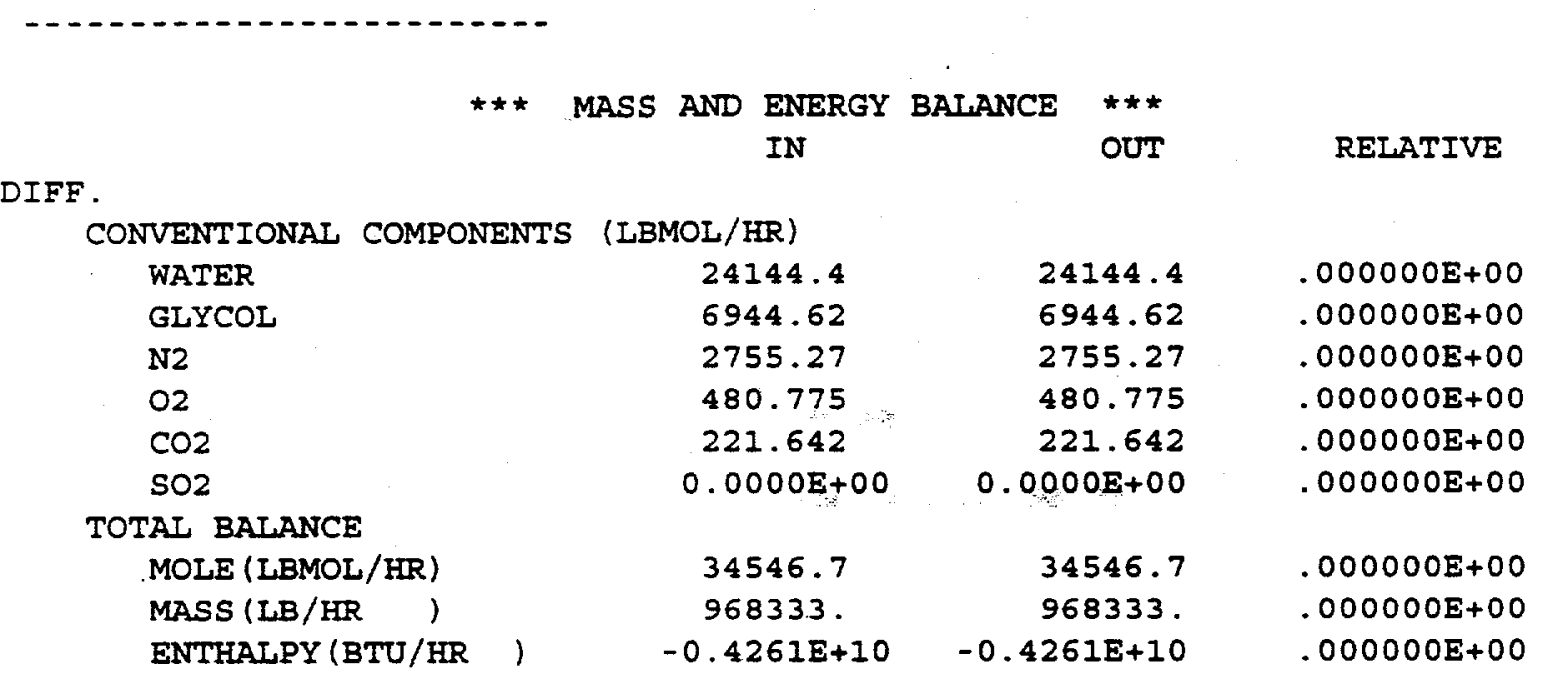




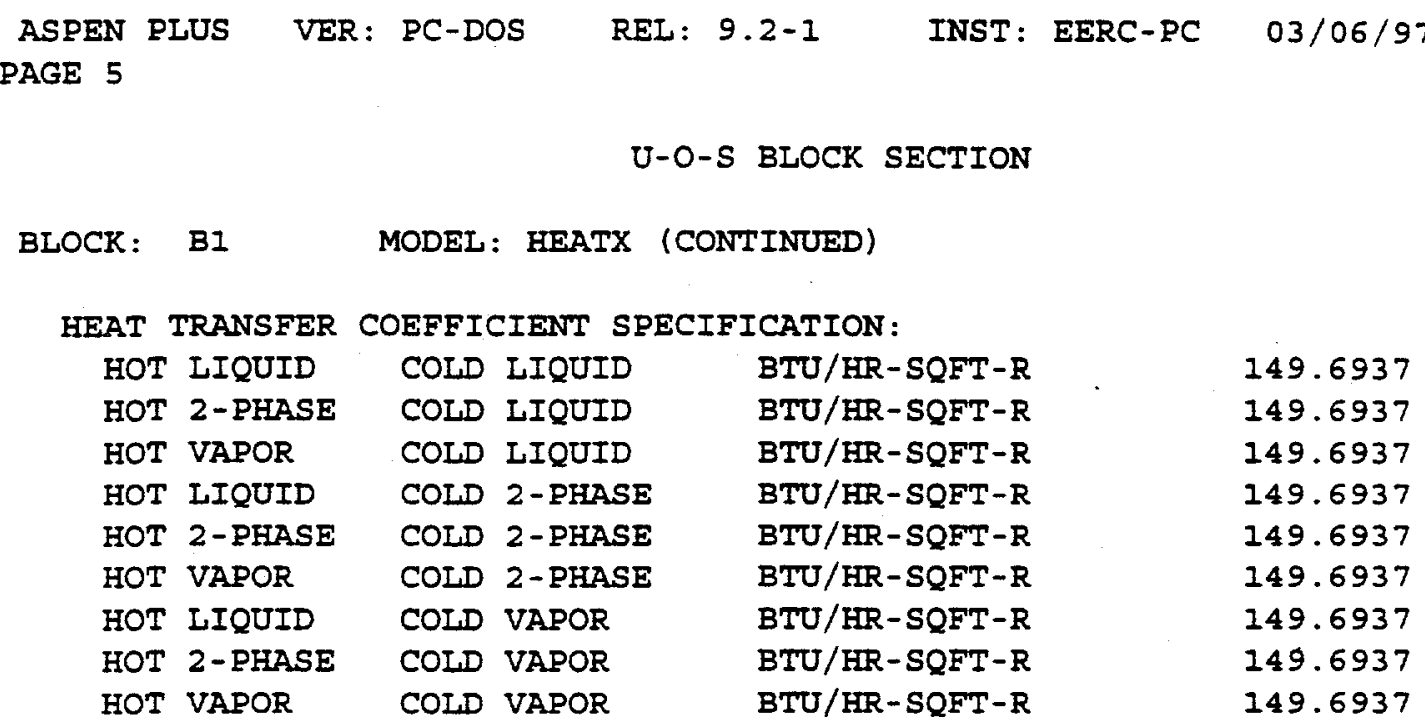

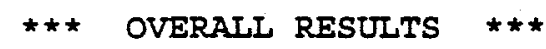

STREAMS :

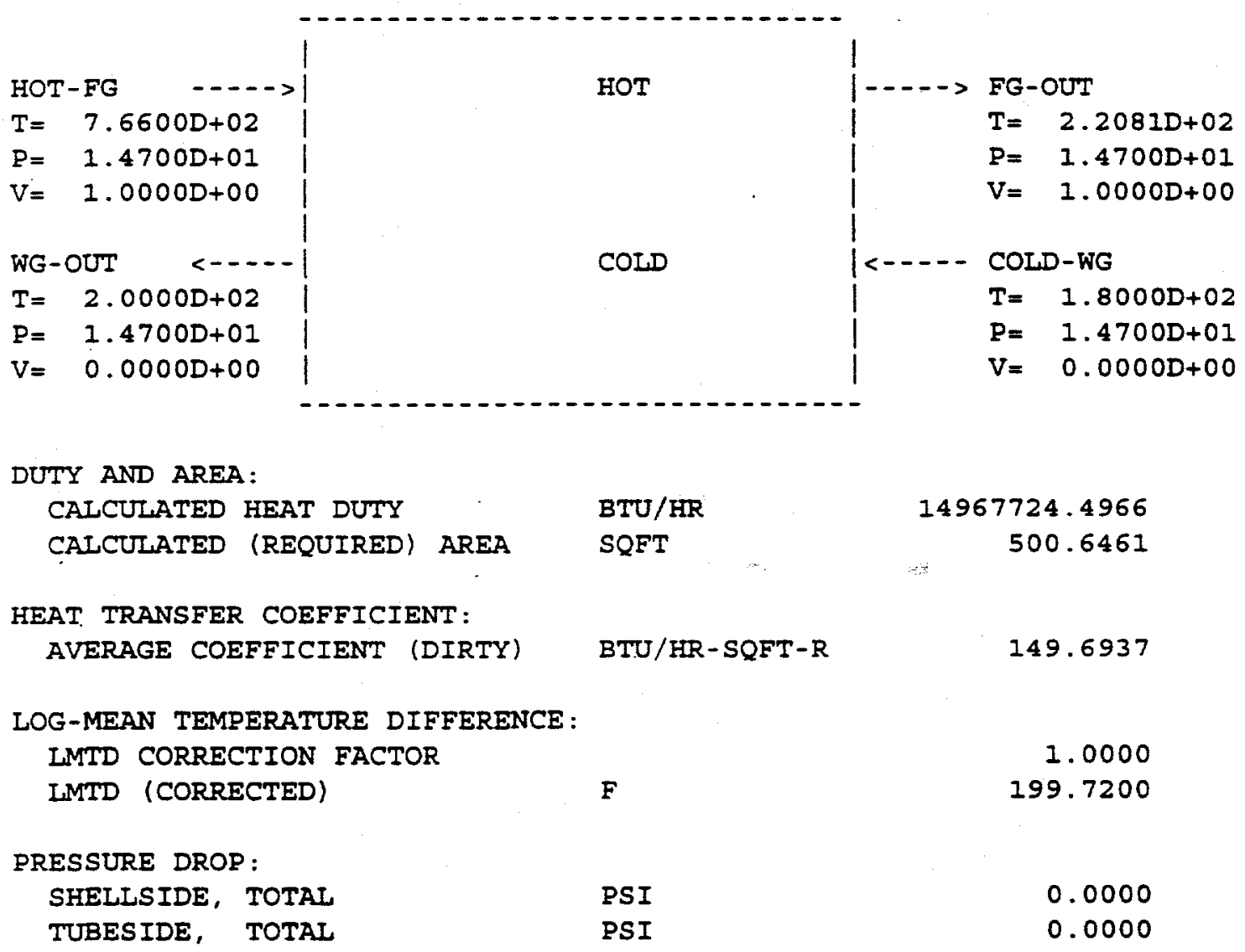



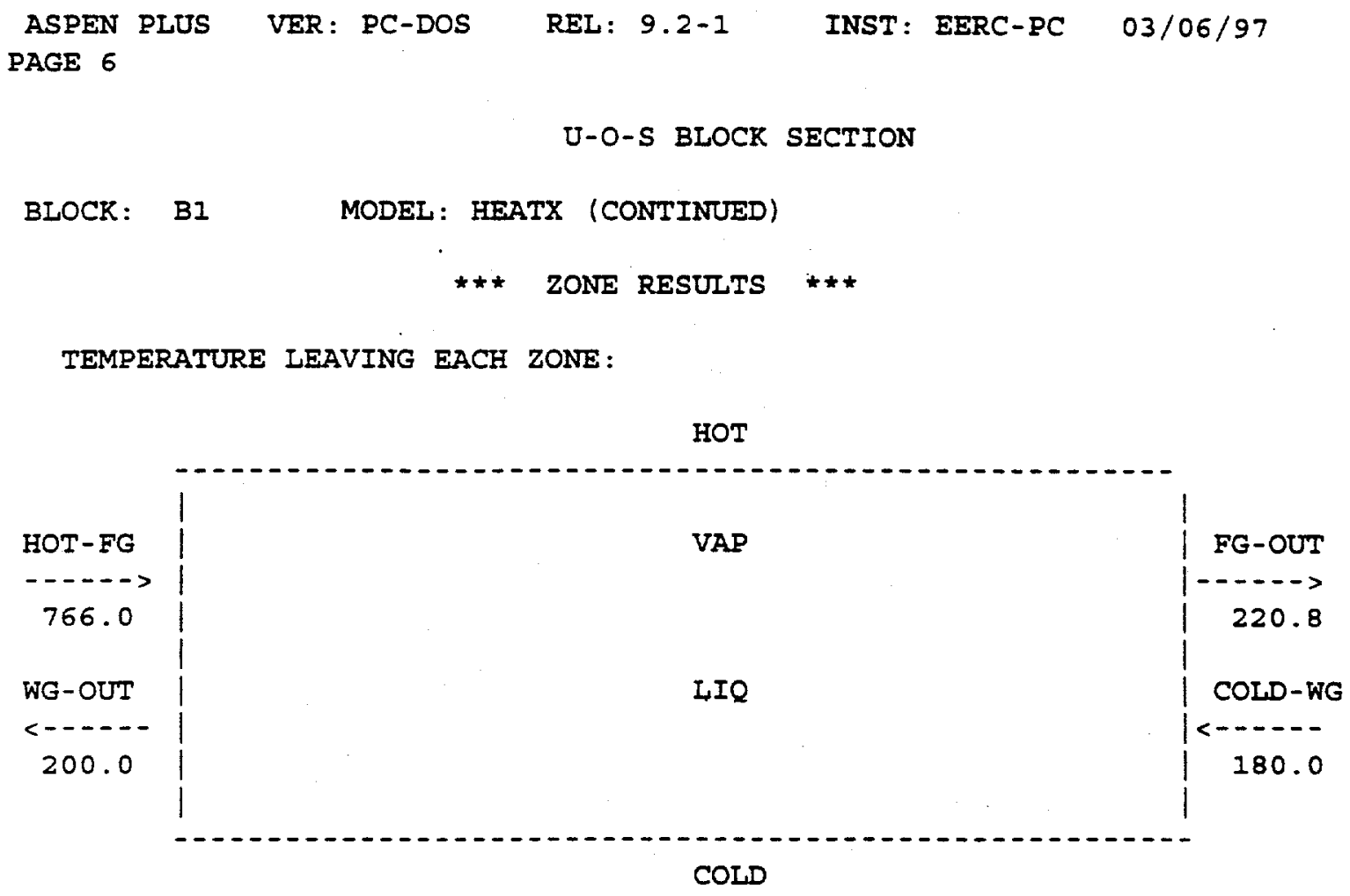

ZONE HEAT TRANSFER AND AREA:

ZONE BEAT DUTY $\mathrm{BTU} / \mathrm{HR}$

SQFT - R

1
AREA

SQFT

500.6461

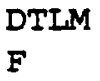

199.7200
AVERAGE U $\mathrm{BTU} / \mathrm{HR}$ 149.6937 
ASPEN PLUS VER: PC-DOS REL: 9.2-1 INST: EERC-PC 03/06/97 PAGE 7

STREAM SECTION

COLD-WG FG-OUT HOT-FG WG-OUT

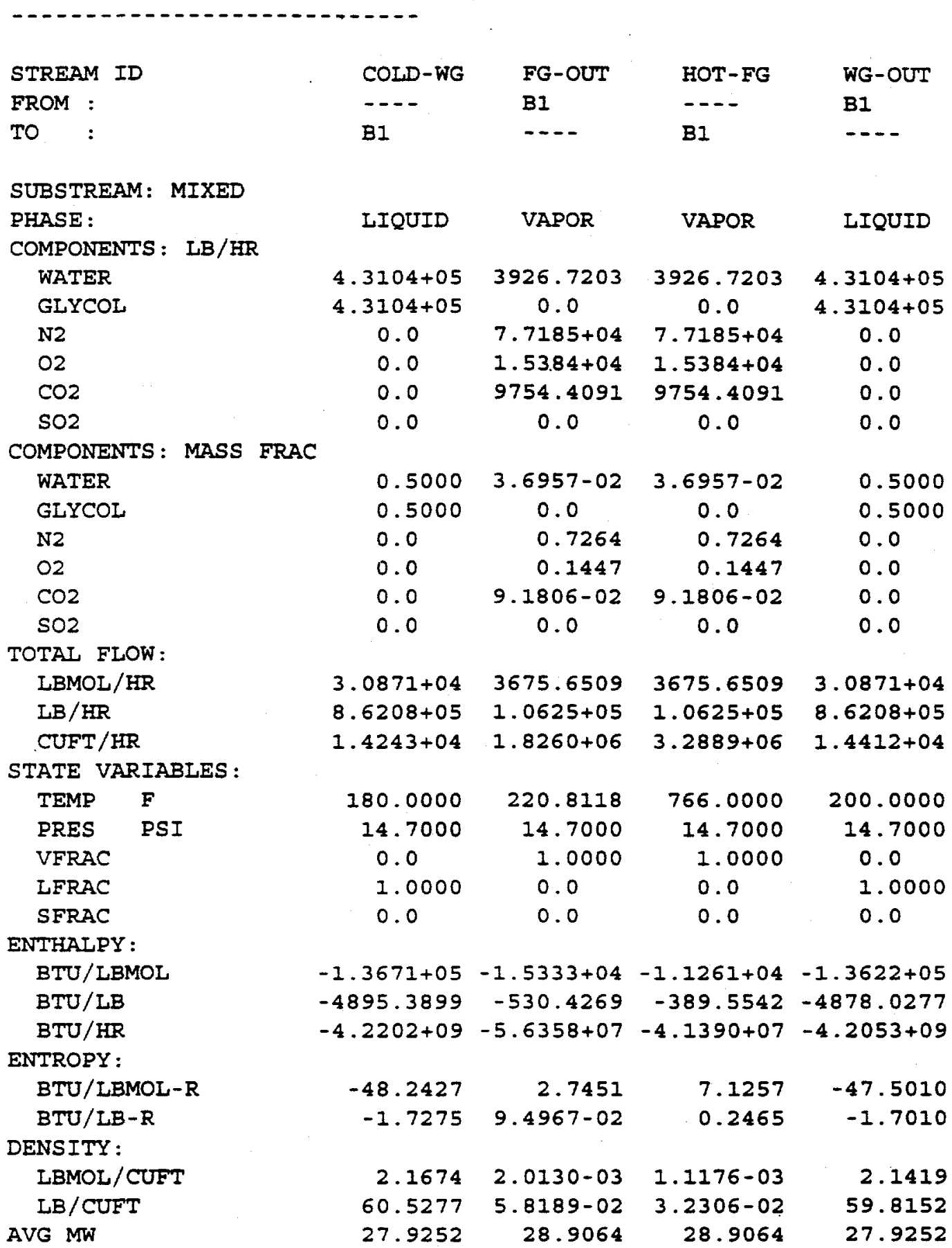


ASPEN PLUS VER: PC-DOS REL: 9.2-1 INST: EERC-PC 03/06/97 PAGE 8

COST BLOCK SECTION

BLOCK: DISTRICT MODEL: HEATX

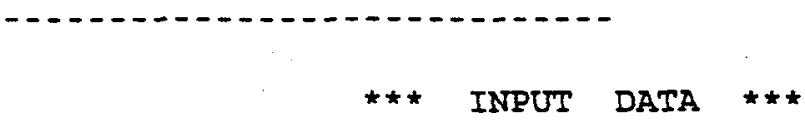

HEAT EXCHANGER TYPE

SHELL MATERIAL

BEM

TUBE MATERIAL

PEAK CAPACITY ALLOWANCE FACTOR

NUMBER OF SHELI PASSES

SHELL PRESSURE

SHELI INLET TEMPERATURE

SHEIL OUTLET TEMPERATURE

NUMBER OF TUBE PASSES

TUBE PRESSURE

TUBE INLET TEMPERATURE

TUBE OUTLET TEMPERATURE

FLOW DIRECTION

HEAT TRANSFER COEFFICIENT

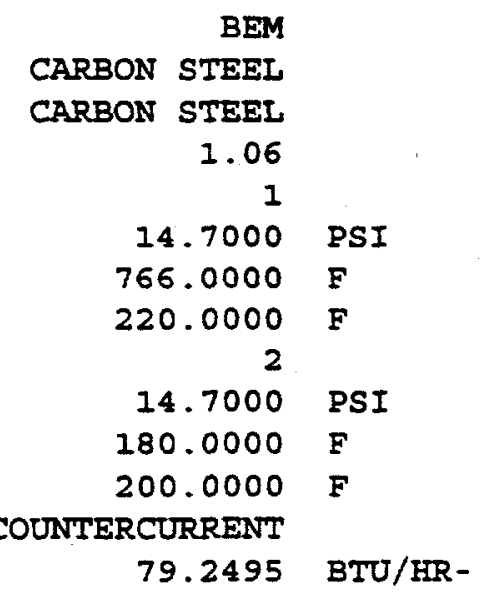
SQFT-R

*** FLOWSHEET REFERENCE DATA ***

BLOCK ID - SHELI SIDE

BLOCK ID - TUBE SIDE

TOTAL HEAT TRANSFER AREA

BTU/HR-

HEAT DUTY

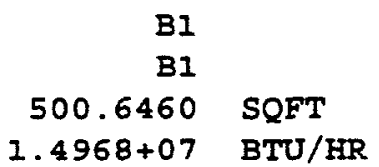

*** SIZING AND COSTING RESULTS

$1.4968+07$

BTU/HR

CALCULATED NUMBER OF HEAT EXCHANGERS

1

MATERIAI OF CONSTRUCTION FACTOR

1.00

HEAT TRANSFER AREA PER UNIT

TOTAL SCAIED HEAT DUTY

LOG MEAN TEMPERATURE DIFFERENCE

EXCHANGER GEOMETRY CORRECTION FACTOR

500.6460

$1.5866+07 \mathrm{BTU} / \mathrm{HR}$

198.5119 F

0.93

\section{$\star \star \star \operatorname{COST}$ RESULTS ***}

CARBON STEEL COST

$\$ \quad 13,245$

PURCHASED COST

$\$ \quad 13,245$ 